\title{
A Water-Budget Model and Assessment of Groundwater Recharge for the Island of Hawai' $i$
}

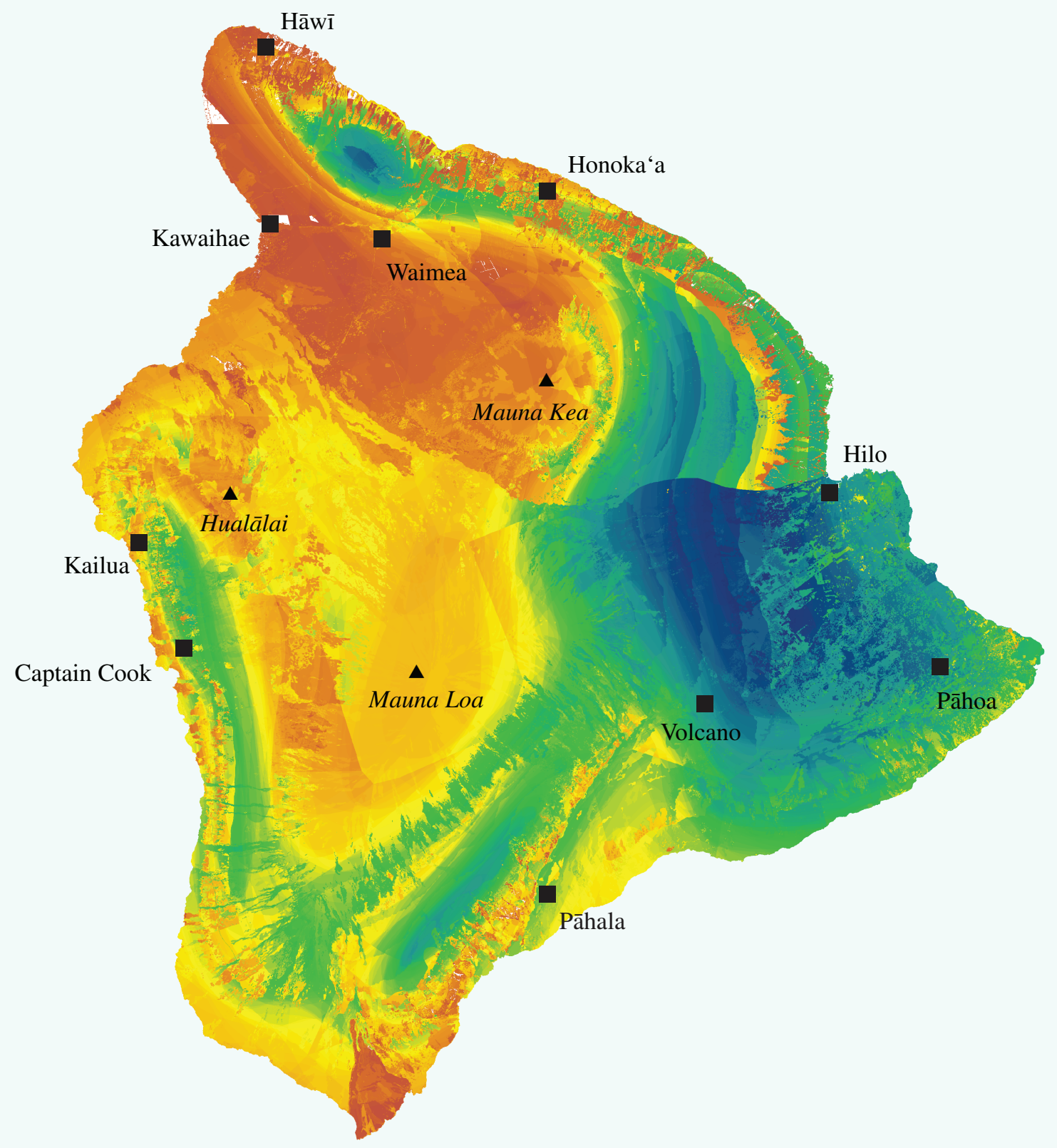

Scientific Investigations Report 2011-5078 
COVER: Map of the Island of Hawai'i showing the relative distribution of estimated mean annual recharge for baseline conditions. Estimated recharge is shown using a spectral color scale with red representing very low recharge and violet representing very high recharge. White areas represent zero estimated recharge. 


\section{A Water-Budget Model and Assessment of Groundwater Recharge for the Island of Hawai' $i$}

By John A. Engott

Scientific Investigations Report 2011-5078 


\title{
U.S. Department of the Interior KEN SALAZAR, Secretary \\ U.S. Geological Survey Marcia K. McNutt, Director
}

\author{
U.S. Geological Survey, Reston, Virginia: 2011
}

This report and any updates to it are available online at: http://pubs.usgs.gov/sir/2011/5078/

For more information on the USGS - the Federal source for science about the Earth, its natural and living resources, natural hazards, and the environment, visit http://www.usgs.gov or call 1-888-ASK-USGS

For an overview of USGS information products, including maps, imagery, and publications, visit http://www.usgs.gov/pubprod

To order this and other USGS information products, visit http://store.usgs.gov

Any use of trade, product, or firm names is for descriptive purposes only and does not imply endorsement by the U.S. Government.

Although this report is in the public domain, permission must be secured from the individual copyright owners to reproduce any copyrighted materials contained within this report.

Suggested citation:

Engott, J.A., 2011, A water-budget model and assessment of groundwater recharge for the Island of Hawai'i: U.S. Geological Survey Scientific Investigations Report 2011-5078, 53 p. 


\section{Executive Summary}

Concern surrounding increasing demand for groundwater on the Island of Hawai ' $i$, caused by a growing population and an increasing reliance on groundwater as a source for municipal and private water systems, has prompted a study of groundwater recharge on the island using the most current data and accepted methods. This report documents the development of a daily water-budget model for computing groundwater recharge for the entire Island of Hawai ' $i$ and the application of the model to estimate mean recharge for various land-cover and rainfall conditions. The development of a submodel for the Kona area and the application of the model to estimate historical groundwater recharge in the Kona area during the period 1984-2008 also are documented. Recharge estimates from this study are compared to recharge estimates used by the State of Hawai'i Commission on Water Resource Management (CWRM) in setting the sustainable yields (maximum allowable pumping rates) of Hawai' $i$ aquifer systems in the 2008 version of the Water Resource Protection Plan (2008 WRPP).

\section{Groundwater Recharge on Hawai'i}

Estimated mean annual recharge on the Island of Hawai ' $\mathrm{i}$ is 6,594 million gallons per day, which is about 49 percent of mean annual rainfall. Recharge is highest on the windward slopes of Mauna Loa, below the tradewind inversion, and lowest on the leeward slopes of Kohala and Mauna Kea (fig. ES1). Local recharge maxima also occur on (1) the higher elevations of windward Kohala, (2) windward Mauna Kea below the tradewind inversion, (3) windward Kilauea, (4) the middle elevations of southeastern Mauna Loa, and (5) the lower middle elevations of leeward Mauna Loa and southwestern Hualālai, in the Kona area. Local recharge minima also occur on (1) Mauna Kea and Mauna Loa, above the tradewind inversion, (2) the northern tip of Kohala, (3) leeward Kîlauea, (4) the southern tip of Mauna Loa, and (5) the northwestern slopes of Mauna Loa and Hualālai.

In 18 of the 24 aquifer systems on the island, mean annual recharge estimated in this study for baseline conditions was higher than the recharge estimates used in the 2008 WRPP (fig. ES2). Baseline conditions for this study were 2008 land cover and mean annual rainfall from the period 1916-1983. The higher recharge estimates for most areas in this study generally are attributable to differences in the methods used to estimate runoff and ET, the inclusion of fog interception in this study, and the shorter time step used in this study. Substantially lower estimates of recharge were calculated for the Māhukona, Waimea, and Hāwī aquifer systems_-38, 34, and 29 percent lower, respectively. These lower estimates mainly are due to much higher ET estimates in this study compared to the 2008 WRPP. This may be cause for concern, because these particular areas are experiencing a growth in development and a related growth in water demand. For the drought simulation performed in this study, the estimates of recharge for all three of these aquifer systems were substantially less than the sustainable yields of the aquifer systems set by CWRM.

Recent projections of change in rainfall owing to effects of ongoing climate change generally indicate a slight increase in islandwide rainfall, and estimates of annual recharge in the late 21 st century are higher than baseline estimates for every aquifer system, except 'Anaeho'omalu. On average, these aquifer-system recharge estimates are higher by about 8 percent compared to baseline estimates.

\section{Recharge in the Kona Area (1984-2008)}

For the Kona submodel, the period 1984-2008 was broken into five subperiods to simplify calculation: 1984-1988, 1989-1993, 1994-1998, 1999-2003, and 2004-2008. Groundwater recharge was highest during 2004-8 and lowest during 1999-2003 (fig. ES3). Estimated mean annual recharge during 1999-2003 was only 50 percent of estimated recharge during 2004-8. These extremes coincided with the periods of lowest and highest mean rainfall, respectively. On a monthly basis, average recharge during the entire 1984-2008 period was highest in January and lowest in August; however, no clear seasonal pattern is discernible. Spatially, the highest recharge occurred in a belt about 4 miles wide running parallel to the coast about 2 miles inland. 


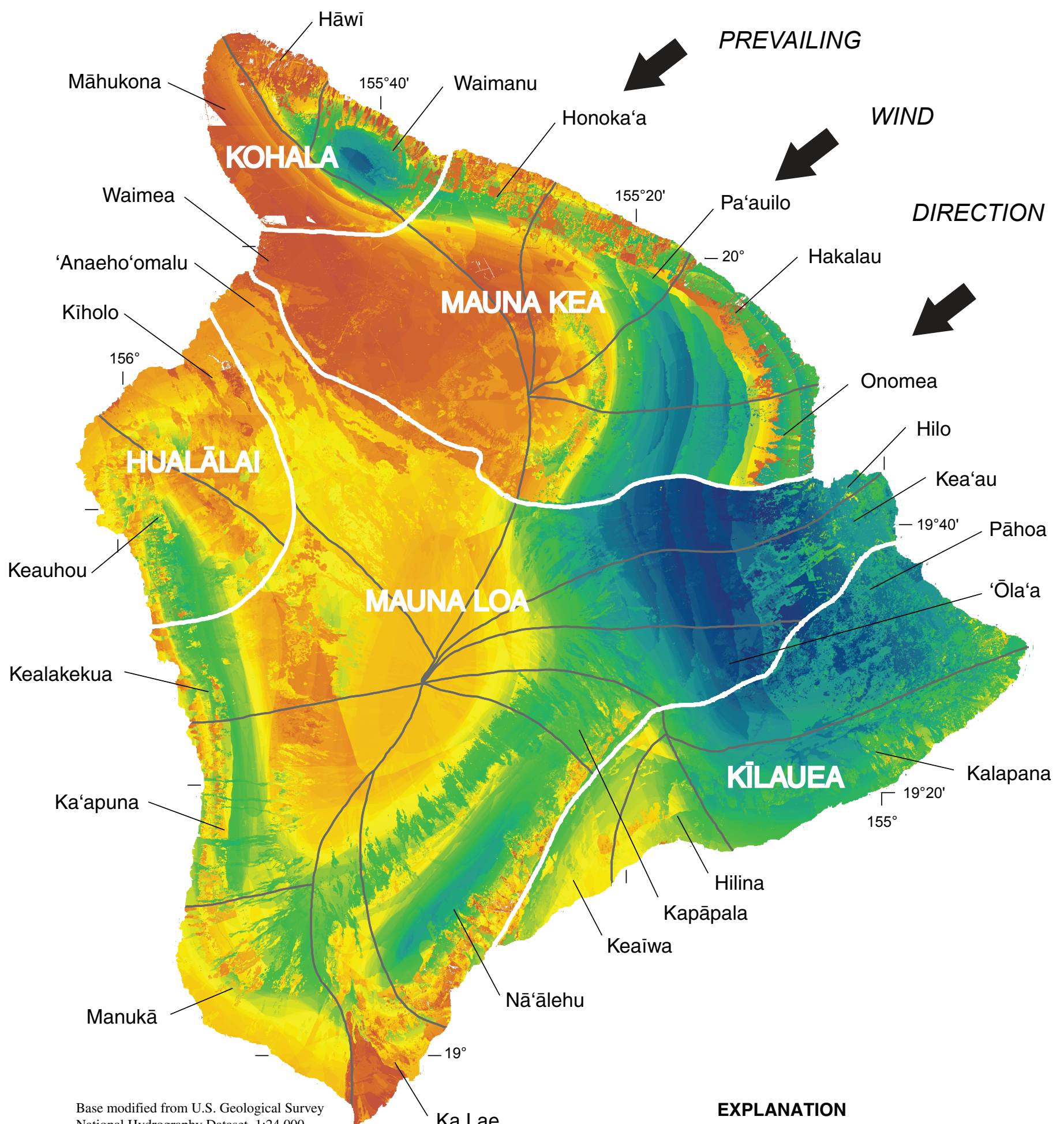
National Hydrography Dataset, 1:24,000, Universal Transverse Mercator projection, zone 5, NAD83 datum.

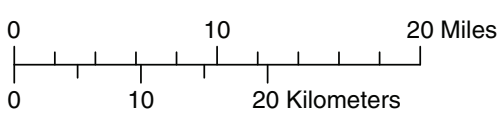

Mean annual groundwater recharge, in inches

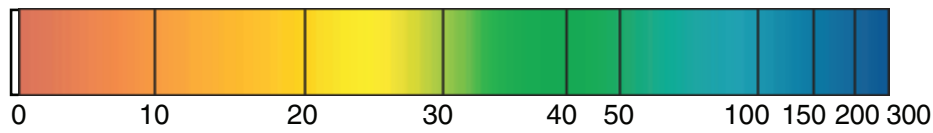

Figure ES1. Distribution of mean annual groundwater recharge for baseline conditions on the Island of Hawai'i calculated using the water-budget model. Areas of zero recharge appear as white. Boundaries of named aquifer systems (State of Hawai'i, 2008) are shown in gray. The generalized boundaries of the surface rocks of the five volcanoes forming the island are shown in white. 


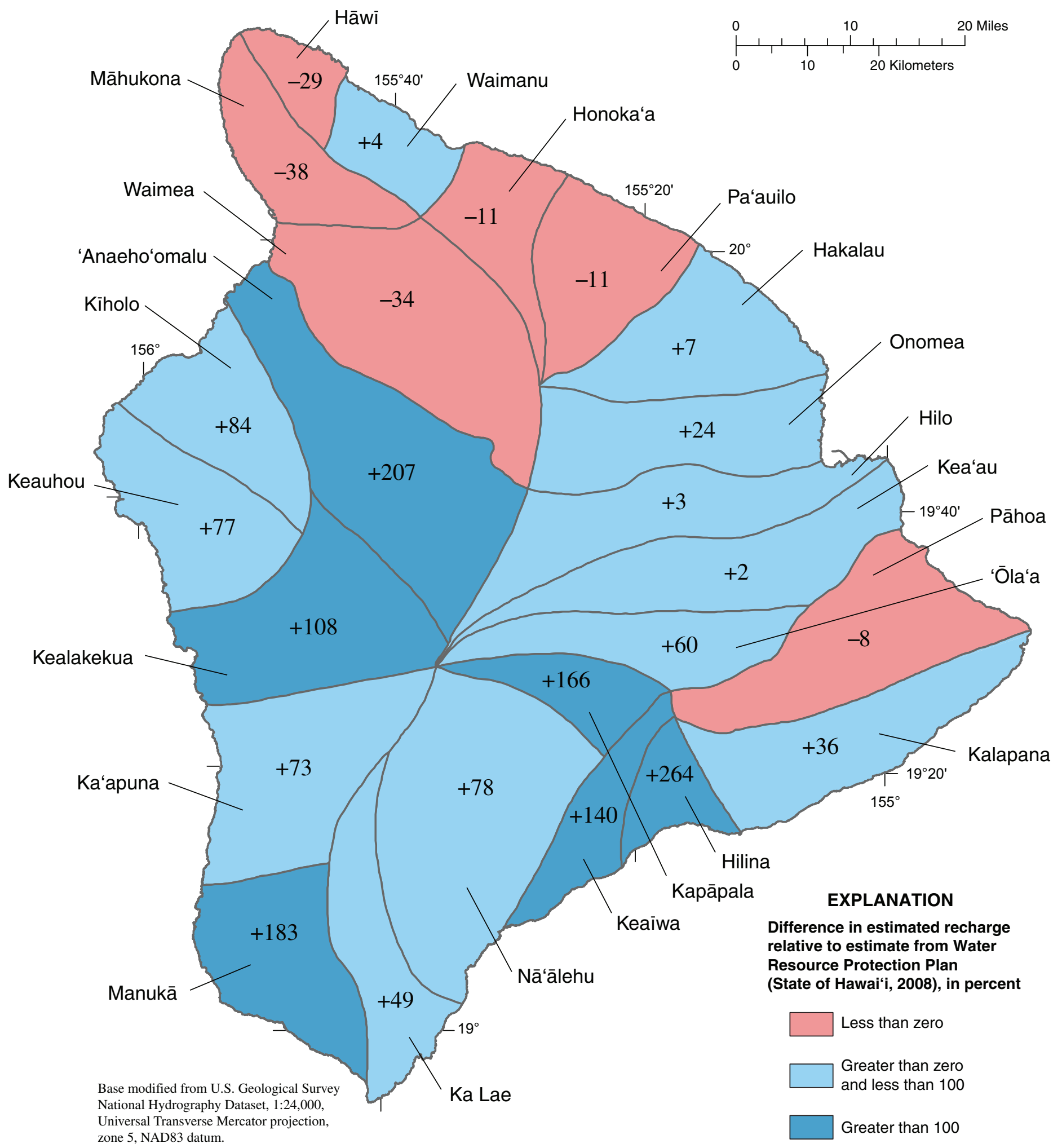

Figure ES2. Relative difference, by aquifer system, between the recharge calculated in this study and the recharge used in the Water Resource Protection Plan (State of Hawai'i, 2008). 


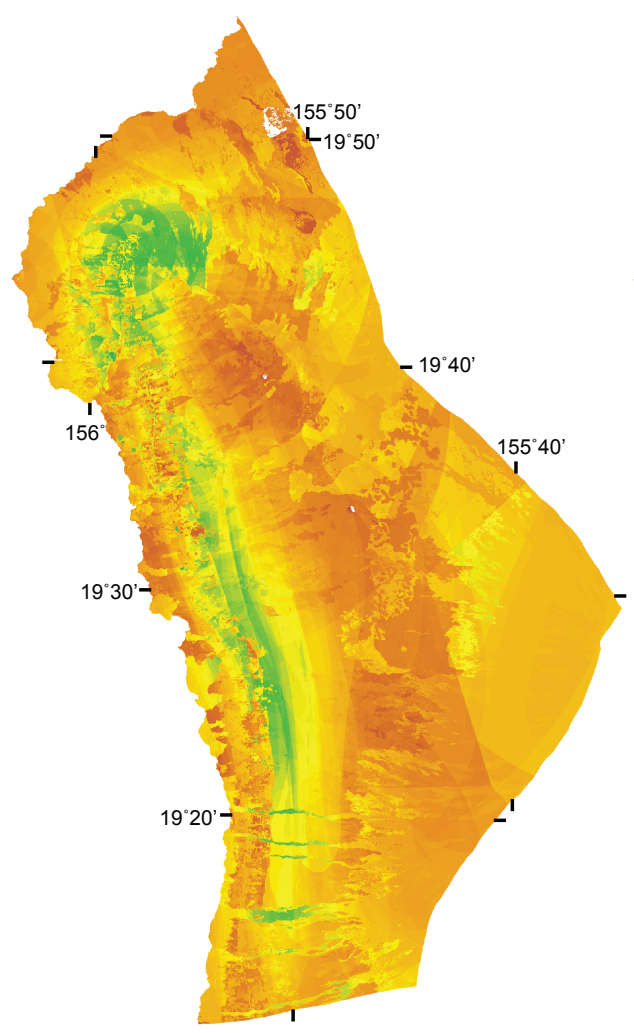

1984-88

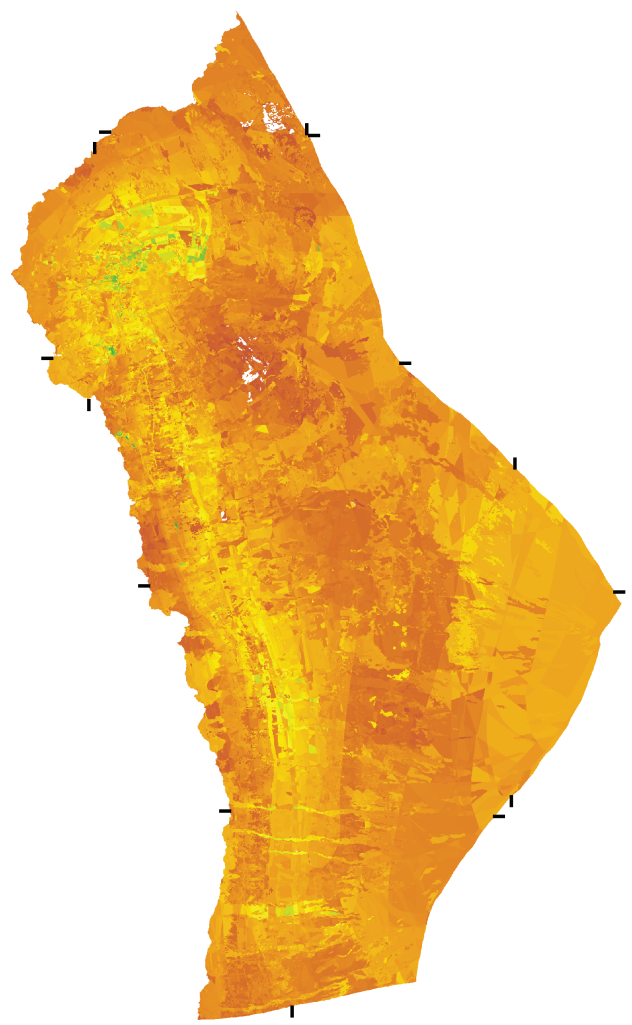

1999-2003

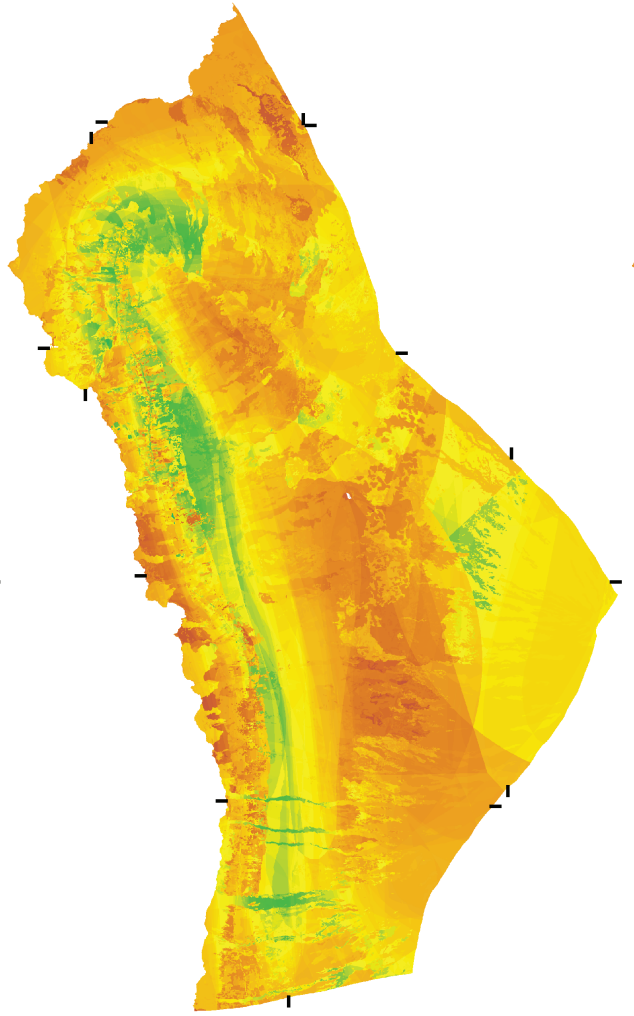

1989-93

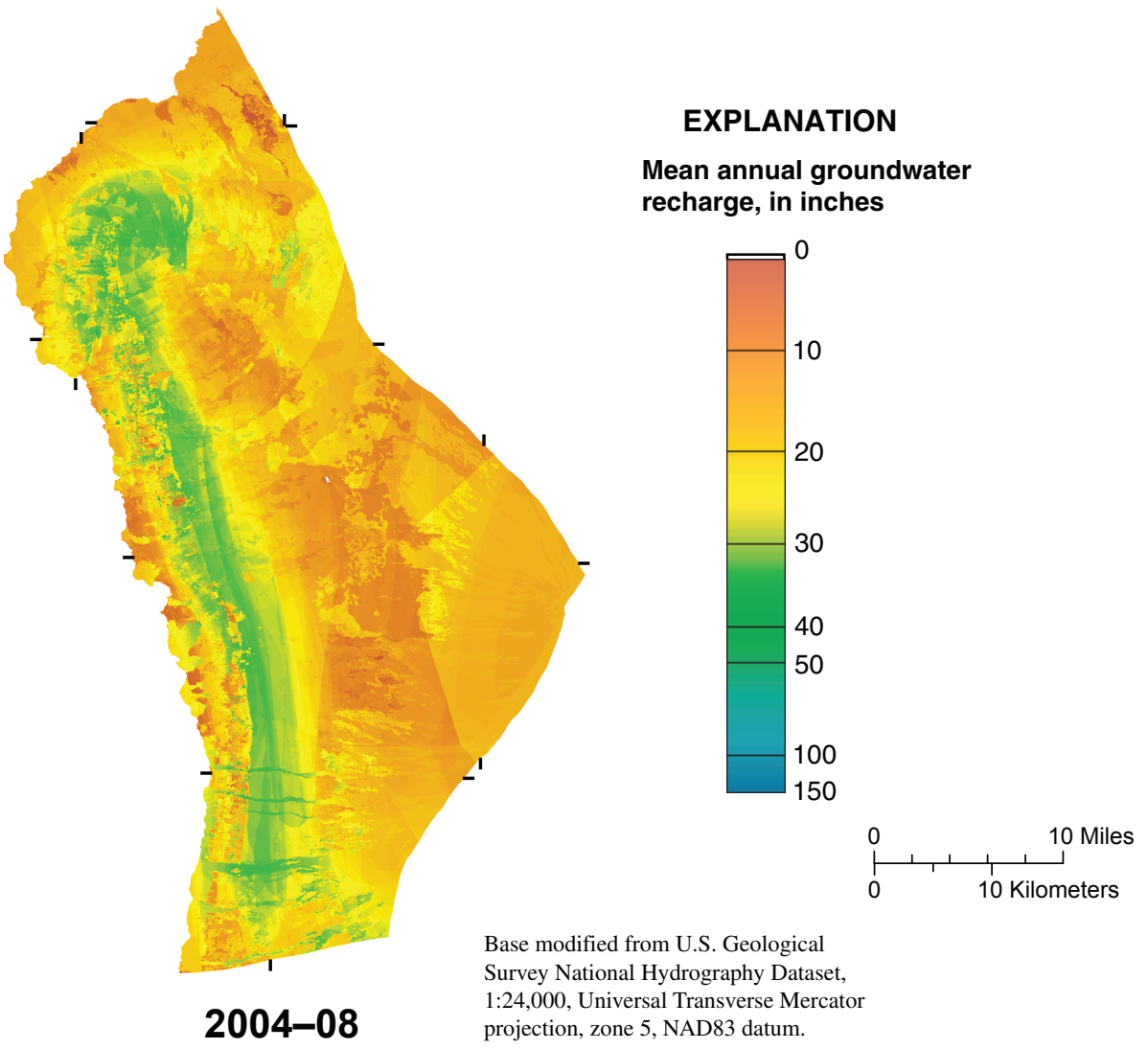

Figure ES3. Distribution of estimated mean annual groundwater recharge during five time periods between 1984 and 2008 calculated using the water-budget model for the Kona area of the Island of Hawai'i. Areas of zero recharge appear as white. 


\section{Contents}

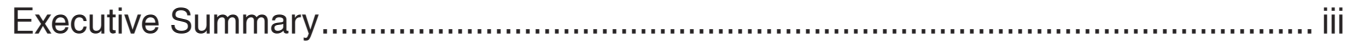

Groundwater Recharge on Hawai'i............................................................. ii

Recharge in the Kona Area (1984-2008) ............................................................ iii

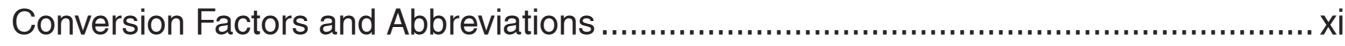

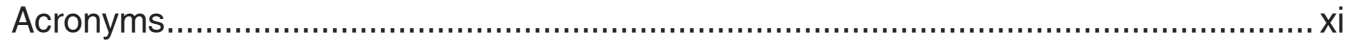

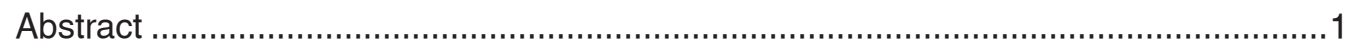

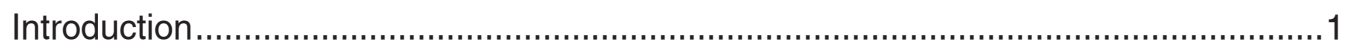

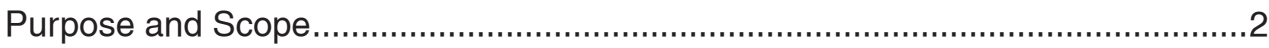

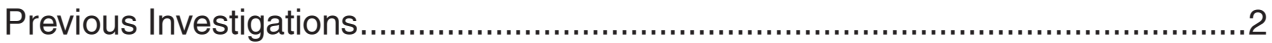

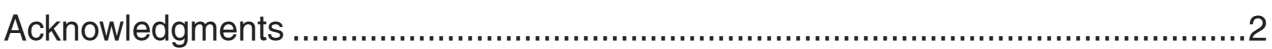

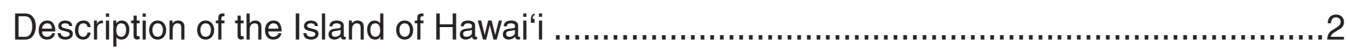

Physical Setting

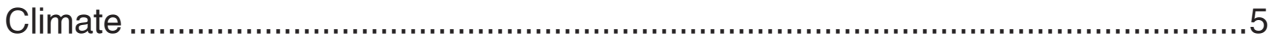

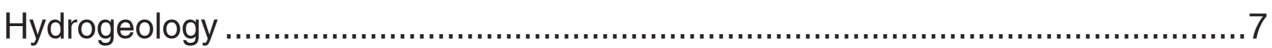

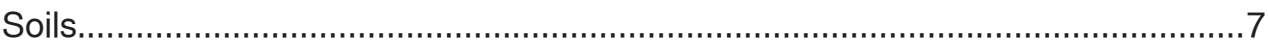

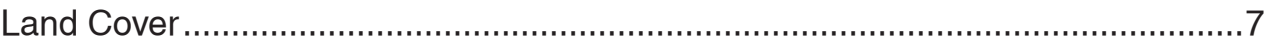

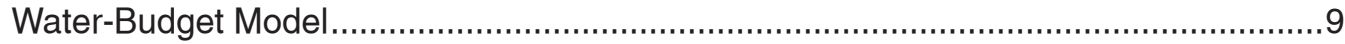

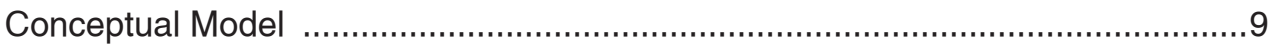

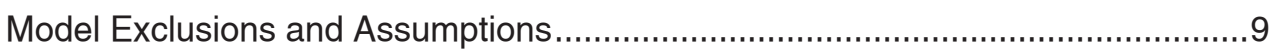

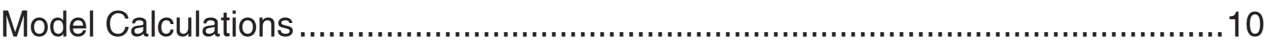

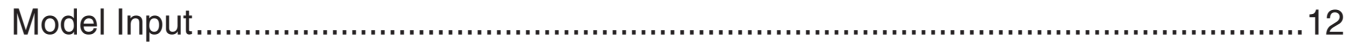

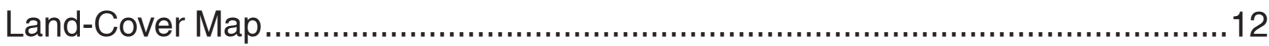

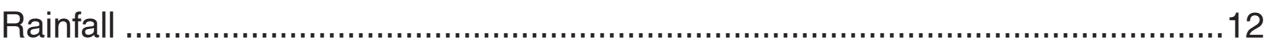

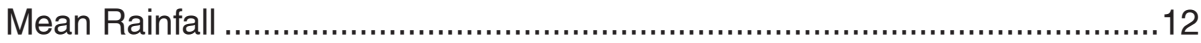

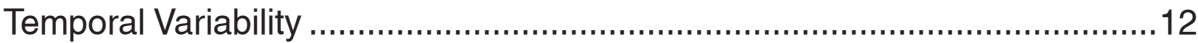

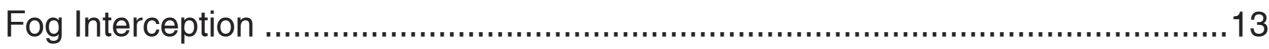

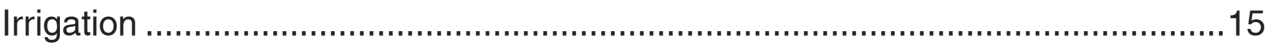

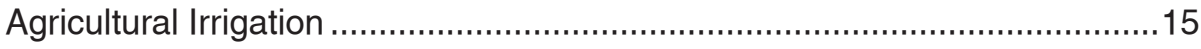

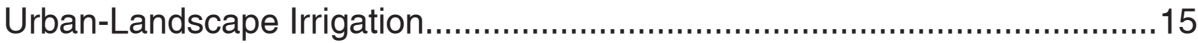

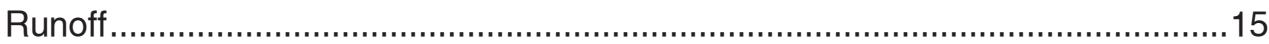

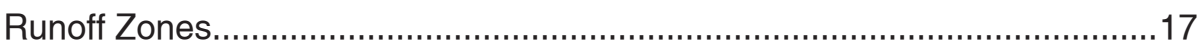

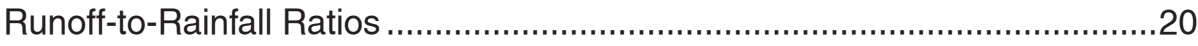

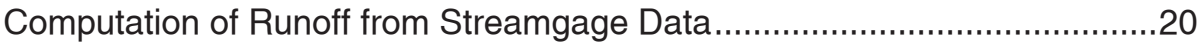

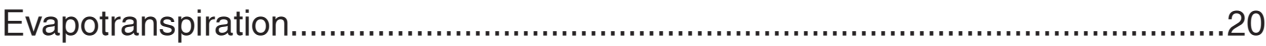

Canopy Evaporation and Net Precipitation ..............................................22

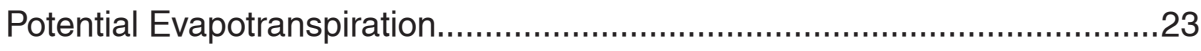

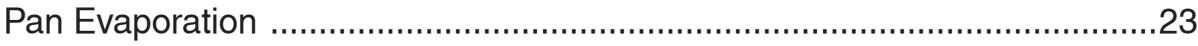

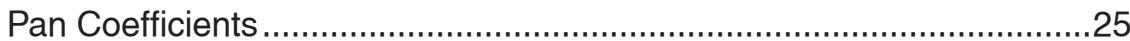

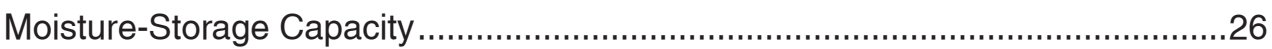

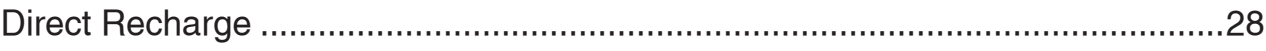

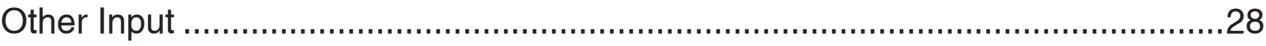

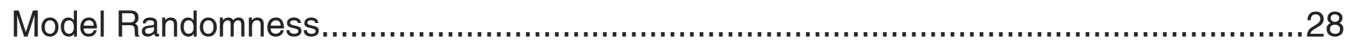




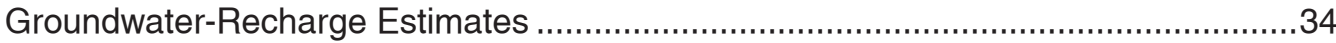

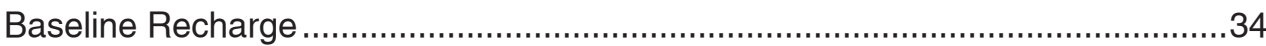

Comparison to Water Resources Protection Plan..........................................36

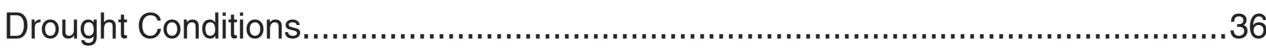

Replacement of Alien Forest with Native Forest ...............................................38

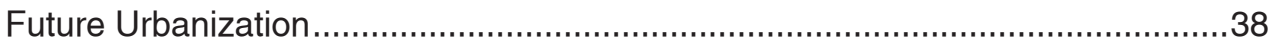

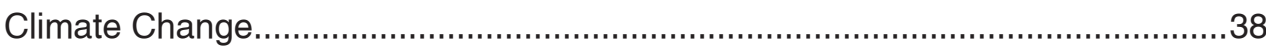

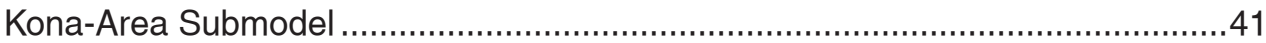

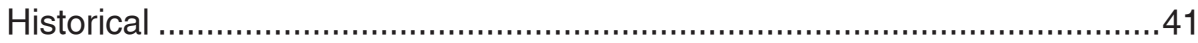

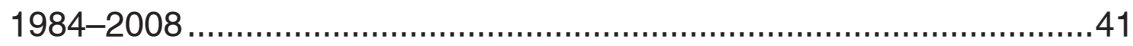

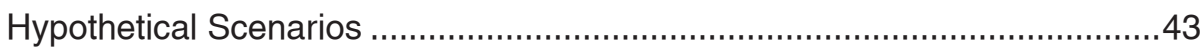

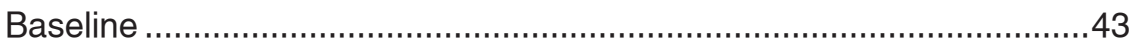

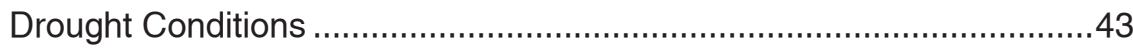

Future Urbanization ..................................................................... 46

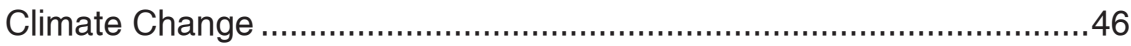

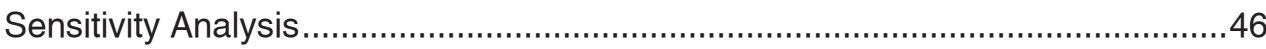

Suggestions for Future Study and Additional Data Collection ...................................48

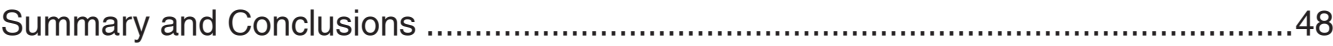

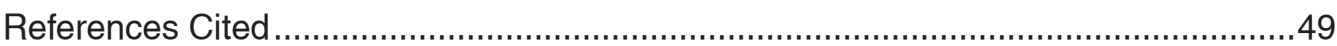

\section{Figures}

ES1. Map showing the distribution of mean annual groundwater recharge for baseline conditions on the Island of Hawai' $i$ iv

ES2. Map showing the relative difference, by aquifer system, between the recharge calculated in this study and the recharge used in the Water Resource Protection Plan

ES3. Maps showing the distribution of estimated mean annual groundwater recharge during five time periods between 1984 and 2008

1. Map of the Island of Hawai'i showing major geographical features and the generalized extent of the surface rocks of the five volcanoes that form the island.

2. Map showing aquifer-systems (State of Hawai'i, 2008), judicial districts, and the Kona water-budget area

3. Map showing mean annual rainfall and locations of rain gages used in the water-budget calculation for the Island of Hawai'i.................................... 6

4. Map showing land cover on the Island of Hawai'i .......................................... 8

5. Generalized water-budget flow diagrams for both forest and nonforest land covers

6. Maps showing the rain-gage stations and the seven rainfall-variability zones used to simulate annual variability of rainfall on the Island of Hawai' $i$....13

7. Map showing areas of fog contribution to the water budget on the Island of Hawai'i

8. Map showing runoff zones defined for the water-budget calculation on the Island of Hawai' $\mathrm{i}$ 
9. Graph showing analysis of the linear relation between net precipitation and fog interception in forests, based on data from studies in the Hawaiian Islands and similar tropical locations around the world.

10. Map showing mean annual pan evaporation and pan-evaporation zones defined for the water-budget calculation on the Island of Hawai'i .........................24

11. Map showing calculated moisture-storage capacity on the Island of Hawai'i.......27

12. Chart showing the average absolute percentage change in recharge of all the water-budget subareas with each successive model simulation.

13. Map showing the distribution of mean annual groundwater recharge for baseline conditions on the Island of Hawai'i calculated using the water-budget model

14. Map showing the estimated fraction of total water inflow that becomes groundwater recharge in the water-budget simulation for mean annual recharge for baseline conditions on the Island of Hawai'i

15. Map showing the relative difference, by aquifer system, between the recharge calculated in this study and the recharge used in the Water Resource Protection Plan

16. Map showing the distribution of mean annual groundwater recharge for drought conditions on the Island of Hawai'i

17. Maps showing three possible distributions of mean annual groundwater recharge during the late 21 st century

18. Vertical bar plot showing estimated groundwater recharge during five historical time periods for the Kona area of the Island of Hawai'i.

19. Maps showing the distribution of estimated mean annual groundwater recharge during five time periods between 1984 and 2008

20. Vertical bar graph showing average ratio of observed to mean annual rainfall for the eight gages used to simulate historical rainfall for the Kona-area water-budget submodel

\section{Tables}

1. Previous water-budget investigations for the Island of Hawai'i..............................5

2. Ratios of observed rainfall to mean rainfall for rain gages used to simulate interannual variability in the water-budget model for the Island of Hawai'i.

3. Ratios of fog interception to rainfall used in the water-budget model for the Island of Hawai'i

4. Land-cover parameters used in water-budget calculations for the Island of Hawai'i

5. Ratios of runoff to rainfall used in the water-budget model for the Island of Hawai'

6. Ratios of monthly to annual pan evaporation for each pan-evaporation zone used in the water-budget calculation for the Island of Hawai'i

7. Mean annual water-budget estimates for baseline and possible future conditions for each aquifer system on the Island of Hawai'i.

8. Comparison of the baseline water budget calculated in this study with other studies for selected aquifer systems on the Island of Hawai'i.....

9. Parameters used for the simulation of late-21st-century rainfall conditions on the Island of Hawai'i. 
10. Linear-regression statistics for normalized pan evaporation versus normalized rainfall used for the climate-change analysis for the Island of Hawai'i. ....

11. Mean annual water-budget estimates for selected historical and hypothetical land-cover and rainfall conditions in the Kona area of the Island of Hawai'i. .43

12. Mean monthly water budgets during five time periods for the Kona area of the Island of Hawai'i

13. Results of sensitivity testing for selected water-budget parameters performed for Onomea, Keauhou, and Waimea aquifer systems on the Island of Hawai'i . 


\section{Conversion Factors and Abbreviations}

Inch/Pound to SI

\begin{tabular}{lcl}
\hline & Multiply & By obtain \\
\hline inch (in.) & Length & \\
inch (in.) & 2.54 & centimeter $(\mathrm{cm})$ \\
foot (ft) & 25.4 & millimeter $(\mathrm{mm})$ \\
mile (mi) & 0.3048 & meter $(\mathrm{m})$ \\
& 1.609 & kilometer $(\mathrm{km})$ \\
\hline acre & Area & \\
acre & 4,047 & square meter $\left(\mathrm{m}^{2}\right)$ \\
square mile $\left(\mathrm{mi}^{2}\right)$ & 0.4047 & hectare $(\mathrm{ha})$ \\
square mile $\left(\mathrm{mi}^{2}\right)$ & 259.0 & hectare $(\mathrm{ha})$ \\
\hline & 2.590 & square kilometer $\left(\mathrm{km}^{2}\right)$ \\
\hline gallon (gal) & Volume & \\
gallon (gal) & 3.785 & liter $(\mathrm{L})$ \\
million gallons $(\mathrm{Mgal})$ & 0.003785 & cubic meter $\left(\mathrm{m}^{3}\right)$ \\
& 3,785 & cubic meter $\left(\mathrm{m}^{3}\right)$ \\
\hline cubic foot per second $\left(\mathrm{ft}{ }^{3} / \mathrm{s}\right)$ & Flow rate & \\
million gallons per day $(\mathrm{Mgal} / \mathrm{d})$ & 0.02832 & cubic meter per second $\left(\mathrm{m}^{3} / \mathrm{s}\right)$ \\
\hline
\end{tabular}

Temperature in degrees Celsius $\left({ }^{\circ} \mathrm{C}\right)$ may be converted to degrees Fahrenheit $\left({ }^{\circ} \mathrm{F}\right)$ as follows:

${ }^{\circ} \mathrm{F}=\left(1.8 \times{ }^{\circ} \mathrm{C}\right)+32$

Temperature in degrees Fahrenheit $\left({ }^{\circ} \mathrm{F}\right)$ may be converted to degrees Celsius $\left({ }^{\circ} \mathrm{C}\right)$ as follows:

${ }^{\circ} \mathrm{C}=\left({ }^{\circ} \mathrm{F}-32\right) / 1.8$

Vertical coordinate information is referenced to mean sea level.

Horizontal coordinate information is referenced to the North American Datum of 1983 (NAD 83).

Elevation, as used in this report, refers to distance above the vertical datum.

\section{Acronyms}

\begin{tabular}{ll}
\hline Acronyms & \multicolumn{1}{c}{ Meaning } \\
\hline CWRM & State of Hawai'i Commission on Water Resource Management \\
ET & Evapotranspiration \\
GAP & Gap Analysis Program \\
GIS & Geographic Information System \\
HDWS & County of Hawai'i Department of Water Supply \\
IPCC & Intergovernmental Panel on Climate Change \\
LUPAG & County of Hawai'i Land Use Pattern Allocation Guide \\
NCDC & National Climatic Data Center \\
NWS & National Weather Service \\
RAWS & Remote Automated Weather Station \\
SCAN & Soil Climate Analysis Network \\
USDA & U.S. Department of Agriculture \\
USGS & U.S. Geological Survey \\
WRPP & State of Hawai'i Water Resource(s) Protection Plan \\
\hline
\end{tabular}


This page left intentionally blank. 


\title{
A Water-Budget Model and Assessment of Groundwater Recharge for the Island of Hawai'i
}

\author{
By John A. Engott
}

\section{Abstract}

Concern surrounding increasing demand for groundwater on the Island of Hawai ' $i$, caused by a growing population and an increasing reliance on groundwater as a source for municipal and private water systems, has prompted a study of groundwater recharge on the island using the most current data and accepted methods. For this study, a daily waterbudget model for the entire Island of Hawai'i was developed and used to estimate mean recharge for various land-cover and rainfall conditions, and a submodel for the Kona area was developed and used to estimate historical groundwater recharge in the Kona area during the period 1984-2008.

Estimated mean annual recharge on the Island of Hawai ' $i$ is 6,594 million gallons per day, which is about 49 percent of mean annual rainfall. Recharge is highest on the windward slopes of Mauna Loa, below the tradewind inversion, and lowest on the leeward slopes of Kohala and Mauna Kea. Local recharge maxima also occur on (1) windward Kohala, with the exception of the northern tip, (2) windward Mauna Kea below the tradewind inversion, (3) windward Kîlauea, (4) the middle elevations of southeastern Mauna Loa, and (5) the lowermiddle elevations of leeward Mauna Loa and southwestern Hualālai, in the Kona area. Local recharge minima also occur on (1) Mauna Kea and Mauna Loa, above the tradewind inversion, (2) the northern tip of Kohala, (3) leeward Kîlauea, (4) the southern tip of Mauna Loa, and (5) the northwestern slopes of Mauna Loa and Hualālai.

In 18 of the 24 aquifer systems on the island, estimated mean annual recharge for baseline conditions was higher than the recharge estimates used in the 2008 State of Hawai'i Water Resource Protection Plan (2008 WRPP). Baseline conditions for this study were 2008 land cover and mean annual rainfall from the period 1916-1983. Estimates of recharge for the Māhukona, Waimea, and Hāwī aquifer systems, however, were between 29 and 38 percent lower than the 2008 WRPP estimates, mainly because of much higher evapotranspiration estimates in this study compared to the 2008 WRPP. For the drought simulation (1991-95 rainfall), the estimates of recharge for these three aquifer systems were only 15 to 33 percent of the sustainable yields (maximum allowable pumping rates) set by the 2008 WRPP. This may be cause for concern, as these areas are experiencing a rapid growth in development and a related growth in water demand.

Recent projections of change in rainfall owing to effects of ongoing climate change generally indicate a slight increase in islandwide rainfall, and estimates of annual recharge in the late 21 st century are higher than baseline estimates for every aquifer system, except 'Anaeho'omalu. On average, these aquifer-system recharge estimates are higher by about 8 percent compared to baseline estimates.

In the Kona area, estimated groundwater recharge during the period 1984-2008 was highest during 2004-8 and lowest during 1999-2003, with the 1999-2003 recharge being about 50 percent of the 2004-8 recharge. These extremes in recharge coincided with the periods of lowest and highest mean rainfall, respectively. No seasonal pattern in recharge is discernible. Spatially, the highest recharge occurred in a belt about 4 miles wide running parallel to the coast about 2 miles inland.

The sensitivity of recharge estimates to input parameters is related to the climate and land-cover conditions of the particular area of study. For the wet, forested areas characteristic of the windward side of the island, recharge was most sensitive to the ratio of runoff to rainfall. For the dry, grassland areas characteristic of the northwestern leeward side of the island, recharge was most sensitive to root depth. For the Kona area, characterized by moderate rainfall and a wide variety of land cover, recharge was most sensitive to the pan coefficient and canopy-evaporation rates in forests.

\section{Introduction}

The rate of groundwater withdrawals from aquifer systems on the Island of Hawai'i likely will increase substantially 
in the near future. This increase will result from growth of resident population and from extension of the municipal water system by the County of Hawai' $i$ Department of Water Supply (HDWS) and other, private systems that will include a greater reliance on groundwater sources. From 1990 to 2008, the resident population of the island grew from 120,317 to 175,784 (U.S. Census Bureau, 2009). The resident population is projected to be 217,718 in 2020 (County of Hawai ' $i$, 2005), an increase of about 81 percent from the 1990 population. Excluding sugarcane-related use, reported groundwater withdrawals increased from about 73 million gallons per day (Mgal/d) in 1988 (State of Hawai 'i, 1989) to about $96 \mathrm{Mgal} / \mathrm{d}$ in 2005 (County of Hawai 'i, 2006). Sugarcane irrigation and processing operations used about $31 \mathrm{Mgal} / \mathrm{d}$ of groundwater in 1988, but sugarcane-related activities had completely ceased before 2005. In some aquifer systems, future water demands are projected to approach or exceed sustainable yields set by the State of Hawai' $i$ (2008), depending on the population projection method used by the County of Hawai'i (2006).

The County of Hawai' $i$ has a goal to replace current surface-water sources with groundwater sources for its municipal water systems, wherever feasible (County of Hawai' $i$, 2006). The County has established the investigation and development of additional groundwater sources as a "course of action" for each district of the island in the County's General Plan (County of Hawai 'i, 2005). Groundwater currently is the main source of domestic water across the island. However, surface water provides water for many households, particularly in the Waimea and Hilo areas (fig. 1), and rain catchments also provide water for many households, particularly in the Puna and $\mathrm{Ka}^{\prime} \overline{\mathrm{u}}$ Districts (fig. 2). Groundwater sources generally are preferred over surface-water sources because groundwater requires less treatment and is more reliable in both quantity and quality than surface water.

A better understanding of recharge will help in assessing the availability of groundwater within island aquifer systems. The rate and distribution of groundwater recharge to island aquifer systems is a controlling factor for the availability of groundwater supplies. Accurate estimation of the spatial distribution of groundwater recharge on the Island of Hawai ' $i$ has been identified as a critical need by the State of Hawai' $i$ Commission on Water Resource Management (CWRM) (State of Hawai'i, 2008).

A better understanding of recharge will also help in the development of accurate groundwater-flow models. Estimates of historical groundwater recharge in the Kona area during the period 1984-2008 are needed for the development and calibration of a groundwater model for the area.

\section{Purpose and Scope}

This report documents the (1) development of a daily water-budget model for computing groundwater recharge for the entire Island of Hawai ' $i,(2)$ application of the model to estimate long-term mean annual recharge for various land-cover and rainfall conditions, and (3) development and application of a Kona-area submodel to estimate historical groundwater recharge in the Kona area during the period 1984-2008. Recharge estimates from this study are compared to previously published recharge estimates, and the sensitivity of recharge estimates to selected water-budget parameters is evaluated.

\section{Previous Investigations}

Previous investigations that calculated water budgets for areas on the Island of Hawai' $i$ are listed in table 1. The present water-budget investigation covers both the entire island and the Kona area. The two previous water-budget investigations that covered the entire island, State of Hawai'i (1990) and Giambelluca and Sanderson (1993), used an annual time step. The one previous investigation for the Kona area (Oki, 1999) also used an annual time step. Use of monthly or annual computational time steps can lead to biased recharge estimates (Giambelluca and Oki, 1987; Oki, 2008). This water-budget study uses a daily time step, which provides a more realistic simulation of short-duration events, such as daily irrigation and episodic rainfall, than annual or monthly time steps (Izuka and others, 2005). Kanehiro and Peterson (1977), Oki (2002), and Pacific Hydrogeologic, LLC (unpublished 2006 report titled "Water budget and numerical analysis of Mahukona aquifer system, North and South Kohala, Hawai 'i”) used daily time steps in their water budgets, which covered various parts of the island.

\section{Acknowledgments}

The author thanks Larry Beck (County of Hawai' $i$ Department of Water Supply) and Lenore Ohye (State of Hawai 'i Commission on Water Resource Management) for providing data and information used in this report. Jeff Perreault, Sarah Rosa, and Tracy Ibarra Saguibo of the U.S. Geological Survey provided valuable assistance preparing data sets used in this report.

\section{Description of the Island of Hawai' $i$}

\section{Physical Setting}

The Island of Hawai' $i$ lies at the southeastern end of the Hawaiian Archipelago in the tropical North Pacific Ocean between longitude $154^{\circ} 48^{\prime} \mathrm{W}$ and $156^{\circ} 04^{\prime} \mathrm{W}$ and between latitude $18^{\circ} 54^{\prime} \mathrm{N}$ and $20^{\circ} 17^{\prime} \mathrm{N}$ (fig.1). Comprising an area of about 4,030 square miles $\left(\mathrm{mi}^{2}\right)$, it is nearly twice as large as the combined areas of the other Hawaiian Islands (Macdonald and Abbott, 1970). The island consists of five volcanoes: Kohala, Mauna Kea, Hualālai, Mauna Loa, and Kīlauea. Mauna Kea is the highest of these volcanoes, rising to an elevation of $13,796 \mathrm{ft}$, and Mauna Loa is the largest by volume. With the 


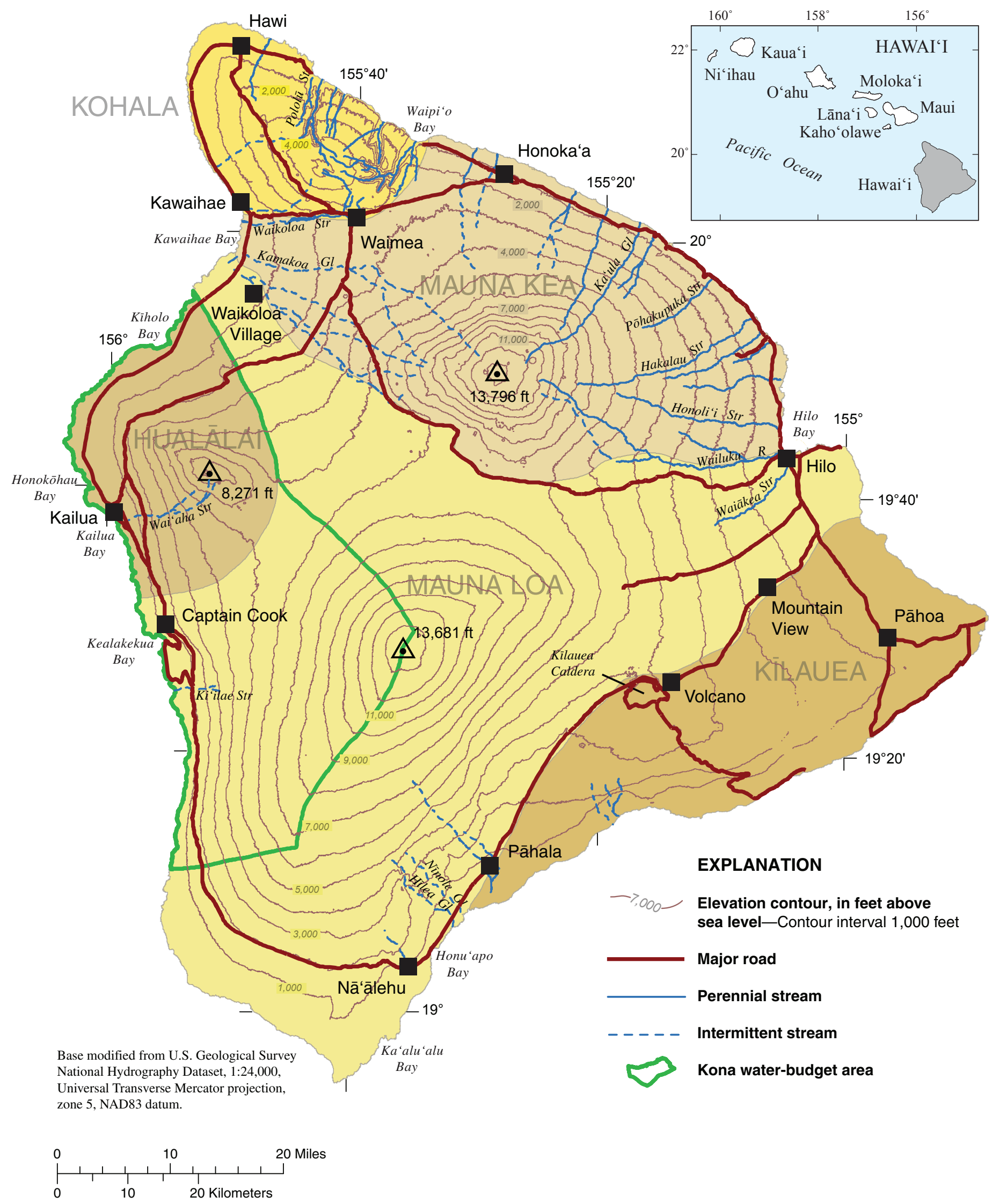

Figure 1. Major geographical features and the generalized extent of the surface rocks of the five volcanoes (colors) that form the Island of Hawai'i. (Modified from State of Hawai'i, 2008). 


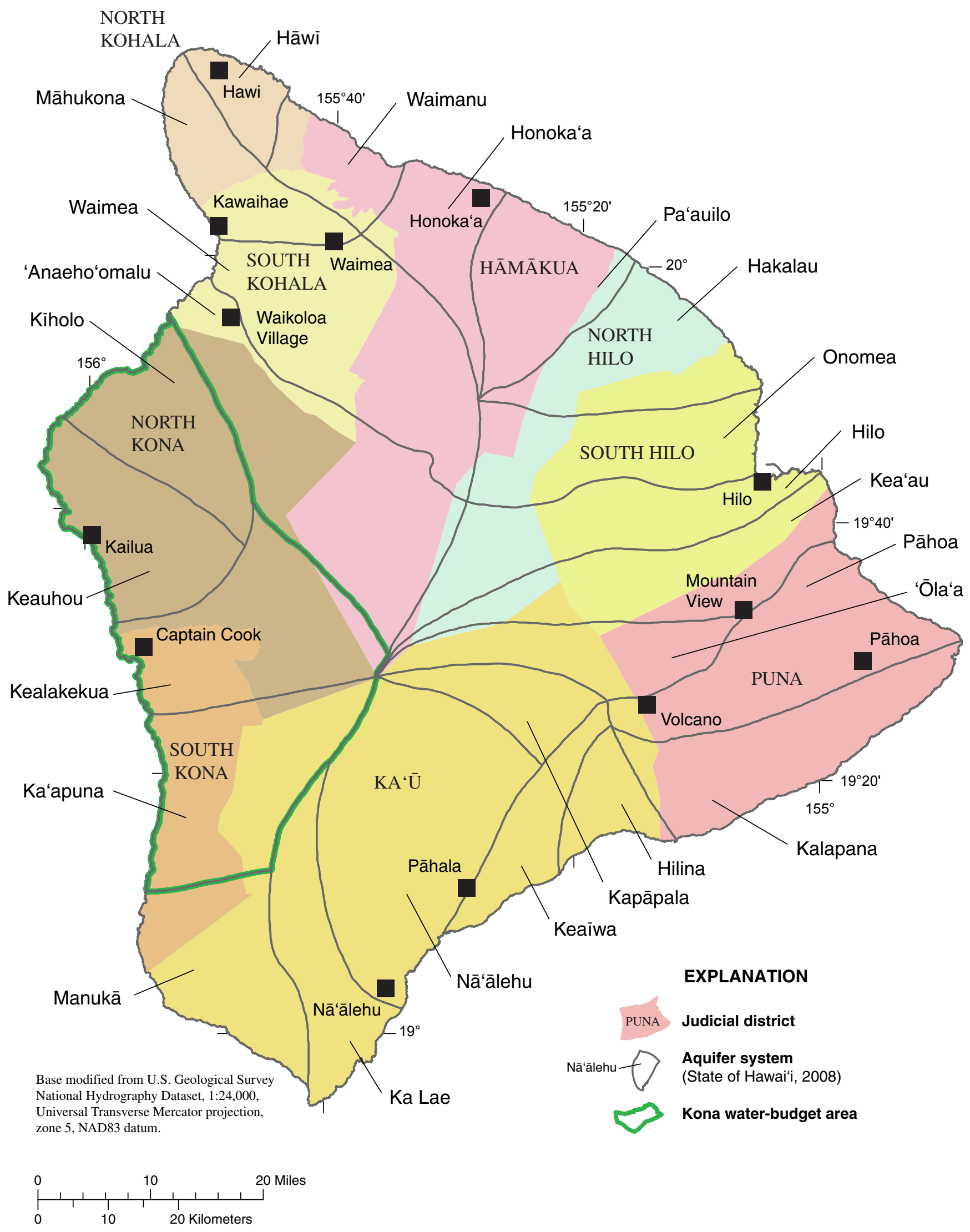

Figure 2. Aquifer systems (State of Hawai' i, 2008), judicial districts, and the Kona water-budget area. 
Table 1. Previous water-budget investigations for the Island of Hawai' $i$.

\begin{tabular}{lll}
\hline \multicolumn{1}{c}{ Reference } & \multicolumn{1}{c}{ Area } & Time step \\
\hline Pacific Hydrogeologic, LLC (2006, unpub.) & Māhukona aquifer system & daily \\
Waimea Water Services (2004) & South Kona and western Ka‘ū districts & monthly \\
Oki (2002) & Hawi area & daily \\
Oki (1999) & Kona area & annual \\
Shade (1995) & Kohala & monthly \\
Giambelluca and Sanderson (1993) & entire island & annual \\
State of Hawai'i (1990) & entire island & annual \\
Kanehiro and Peterson (1977) & part of northwestern coast & daily \\
\hline
\end{tabular}

exception of the northeastern slopes of Kohala and Mauna Kea, the geologically youthful land surface still retains a broadly rounded, shield-shaped morphology that slopes undissected from the volcanic summits to the ocean, except where cinder cones have formed and where erosion from watercourses has created shallow valleys. On the northeastern sides of Kohala and Mauna Kea, large streams, resulting from heavier rainfall, have carved deep valleys in these relatively older volcanoes.

\section{Climate}

The climate on the Island of Hawai' $i$ is extremely diverse-lava deserts, tropical rain forests, and snow-capped mountain peaks all exist. Using the Thornthwaite climatic classification, the island has semiarid, subhumid, humid, and perhumid zones (Giambelluca and Sanderson, 1993). The average annual air temperature of the island ranges from about $73^{\circ} \mathrm{F}$ near the coast to less than $43^{\circ} \mathrm{F}$ near the summits of Mauna Kea and Mauna Loa (Nullet and Sanderson, 1993). Average annual rainfall ranges from about 9 in. near Kawaihae to about $240 \mathrm{in}$. just west of Hilo, on the eastern slope of Mauna Kea (fig. 3).

Climate is primarily controlled by a complex topography, a temperature inversion, and the location of the North Pacific anticyclone, which produces persistent northeasterly winds that are known as tradewinds. During the summer (May through September), tradewinds blow 80 to 95 percent of the time, and during the winter (October through April), when the anticyclone moves southward, tradewinds blow 50 to 80 percent of the time (Blumenstock and Price, 1967; Sanderson, 1993). A temperature inversion, which marks the lower extent of dry air subsiding in the North Pacific anticyclone, exists at a mean elevation of about 6,560 ft over Hawai' $i$ (Schroeder, 1993). This inversion, commonly referred to as the tradewind inversion, greatly influences the climate and vegetation on the mountain slopes. Diurnal and annual variability in climatic variables such as solar radiation, air temperature, and humidity, are affected by the elevation of the inversion (Giambelluca and Nullet, 1991).
The tradewind inversion restricts the upward flow of air (Mendonca and Iwaoka, 1969), forcing the tradewinds around, instead of over, Mauna Loa and Mauna Kea. Tradewind flow around the mountains generates a quasi-stationary cyclonic eddy at the northern end of the leeward side of the island and a stationary anticyclonic eddy at the southern end of the leeward side (Pratzert, 1969; Yang and Chen, 2003). Lowlevel convergence of these counter-rotating eddies over the ocean generates a moisture-enhanced return flow of air to the Kona area, which lies in the wake of Hualālai and Mauna Loa (Yang and Chen, 2003). Daytime solar heating of the island interior creates a diurnal sea-breeze/land-breeze circulation on both the windward and leeward sides of the island, with sea breezes occurring during the day and land breezes occurring at night. The interaction of the tradewind flow pattern with the diurnal sea-breeze/land-breeze circulation determines local wind conditions. Because the Kona area is sheltered from the tradewinds by Hualālai and Mauna Loa, the daily weather there is frequently dominated by a well-developed diurnal seabreeze/land-breeze circulation.

Orographic lifting of onshore winds is the primary rainfall-producing mechanism on the Island of Hawai ' $i$ (Giambelluca and others, 1986). Rainfall generally is greatest on the northeastern and eastern sides of the volcanoes that are exposed to persistent, moist tradewind flow off the ocean, sometimes enhanced by the sea-breeze/land-breeze circulation. Maximum rainfall along the Kona coast occurs where the convective onshore sea breeze is enhanced by the moist return flow (Yang and Chen, 2003). Except in the Kona area, the wettest months on the island occur during the winter, when migratory storm systems bring additional, widespread rain. Because the main rainfall-producing mechanism in the Kona area is related to the convergence of the counter-rotating eddies generated by the tradewinds, which are most persistent in the summer, rainfall in the Kona area is greatest in the summer months (Giambelluca and others, 1986).

On the Island of Hawai' $i$, mountain fog commonly occurs during periods of onshore, upsloping winds and is associated with rainfall. However, it can also occur in the absence of rainfall, especially during the summer when the more frequent 


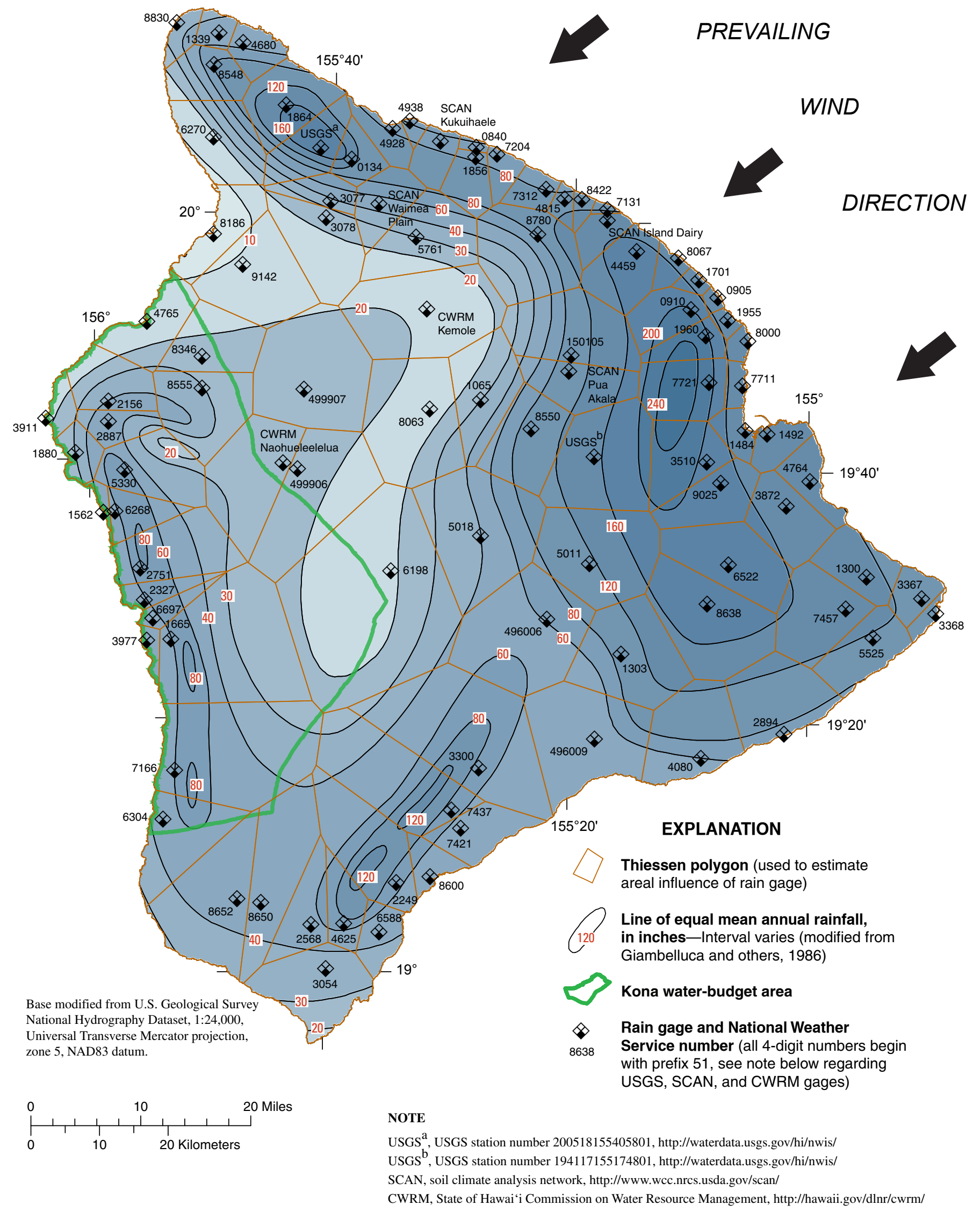

Figure 3. Mean annual rainfall and locations of rain gages used in the water-budget calculation for the Island of Hawai'i. 
presence of the tradewind inversion limits the vertical development of the orographic cloud. This type of fog can persist with relatively high wind velocities, resulting in extremely large volumes of water passing near the ground (Juvik and Ekern, 1978). The interception of fog by vegetation is an important source of water for high-elevation forests in Hawai ' $i$, particularly during the drier summer months (Juvik and Nullet, 1995).

\section{Hydrogeology}

The Island of Hawai' $i$ is formed primarily by the shield-stage volcanic rocks of Mauna Loa and Kîlauea and the shield- and postshield-stage volcanic rocks of Kohala, Hualālai, and Mauna Kea (Langenheim and Clague, 1987). The volcanic rocks can be divided into three main groups on the basis of modes of emplacement-lava flows, dikes, and pyroclastic deposits. In general, lava flows that erupt from the central caldera and the rift zones of each volcano are less than $10 \mathrm{ft}$ thick and are either pahoehoe, which is characterized by smooth, ropy surfaces, or a'a, which contains a massive central core typically sandwiched between rubbly clinker layers. A'a flows typically are more abundant at greater distances from eruptive sources (Lockwood and Lipman, 1987). Dikes are thin, near-vertical sheets of massive rock that intrude existing rocks, commonly lava flows. Dikes are commonly exposed by erosion within the rift zones of older volcanoes (see for example Takasaki and Mink, 1985), including Kohala on the island of Hawai' $i$. The dikes and the rocks they intrude are collectively referred to as dike complexes. In the central part of a rift zone, there can be as many as 1,000 dikes per mile of horizontal distance across the zone (Takasaki and Mink, 1985). The number of dikes decreases toward the outer edges of a rift zone. Within the central part of a dike complex, the dike rocks typically compose 10 percent or more of the total rock volume. At the outer part of the dike complex, within the marginal dike zone, dikes usually constitute less than 5 percent of the total rock volume (Takasaki and Mink, 1985). Pyroclastic rocks are composed of fragments of volcanic rocks that form by explosive volcanic activity and that are deposited by transport processes related to this activity. Pyroclastic rocks, such as ash, cinder, and spatter, can be deposited during all of the subaerial stages of eruption but probably form less than 1 percent of the mass of a Hawaiian volcano (Wentworth and Macdonald, 1953).

The high primary porosity and lack of weathering in the youthful, voluminous lava flows erupted during the shield stage on the Island of Hawai' $i$ provide an aquifer that has relatively high permeability, particularly in the dike-free flanks that slope away from the summits and rift zones. For example, estimates of the hydraulic conductivity for flank lava flows on the west side of the island are as high as several thousand feet per day (Oki, 1999). Within the dike-free flank lavas, fresh groundwater occurs in a lens-shaped body underlain by saltwater from the ocean. Between this freshwater lens and the underlying saltwater is a zone of mixing containing brackish water. The freshwater lens is thin in most areas, owing to the high permeability of the aquifer. The water table is near sea level at the coast and rises gently from less than a foot to a few feet per mile in the inland direction (Stearns and Macdonald, 1946). Natural discharge from the freshwater-lens system generally occurs as diffuse seepage near the coast.

The permeability of volcanic rocks is variable and depends on the type (lava flows, intrusive dikes, or pyroclastic deposits), amount of weathering, and the thickness of the rocks. Dikes that intrude the lava flows impede the flow of groundwater and reduce the overall permeability of the aquifer. Estimated bulk hydraulic conductivity of dike complexes can be several orders of magnitude lower than that of dike-free flank lavas (Oki, 1999). Some other rocks and structures, such as ash layers, soil and weathered rock, unusually thick lava flows, and lava-draped faults, may also form low-permeability features within the otherwise high-permeability lavas of the shield volcano (Stearns and Macdonald, 1946; Oki, 1999). These low-permeability features can increase the thickness of the freshwater lens on the upgradient side of the feature. In dike complexes, highly permeable volcanic rocks can be compartmentalized and groundwater impounded to several thousand feet above sea level (Stearns and Macdonald, 1946).

\section{Soils}

About 39 percent of the land surface on the Island of Hawai' $\mathrm{i}$ is categorized as lava flow or rock land (U.S. Department of Agriculture, 2008). Little to no soil cover exists in these areas. The remainder of the land surface is covered by 148 different soils from 6 soil orders: andisols, aridisols, entisols, histosols, inceptisols, and mollisols (U.S. Department of Agriculture, 2008). The most prevalent soil order on the island is andisols, which are derived from volcanic ash. Andisols cover most of Mauna Kea and parts of all the other volcanoes. Histosols, derived from organic material, are the second most prevalent and exist mainly on the lower flanks of Mauna Loa, Hualālai, and Kîlauea. The thickness of soil on the island is spatially variable and depends on many local factors, including (1) the age of the bedrock (lava flows), (2) the rate of bedrock weathering, (3) the amount and type of vegetation, and (4) the topography of the area (Jenny, 1994).

\section{Land Cover}

Land cover on the Island of Hawai 'i reflects the extreme diversity of climate, recent and ongoing volcanism, and the influence of human activity. Large tracts of forest, generally dominated by the native canopy species Metrosideros polymorpha (ohia lehua) (Loope, 1998), exist in the wetter areas of the island, with shrubland and grassland in the drier areas (fig. 4). Sparsely vegetated land generally exists on lava flows that have not been sufficiently weathered to allow for plant colonization. Native plant species are being replaced by invasive alien species at varying rates in different locations. Asner and 


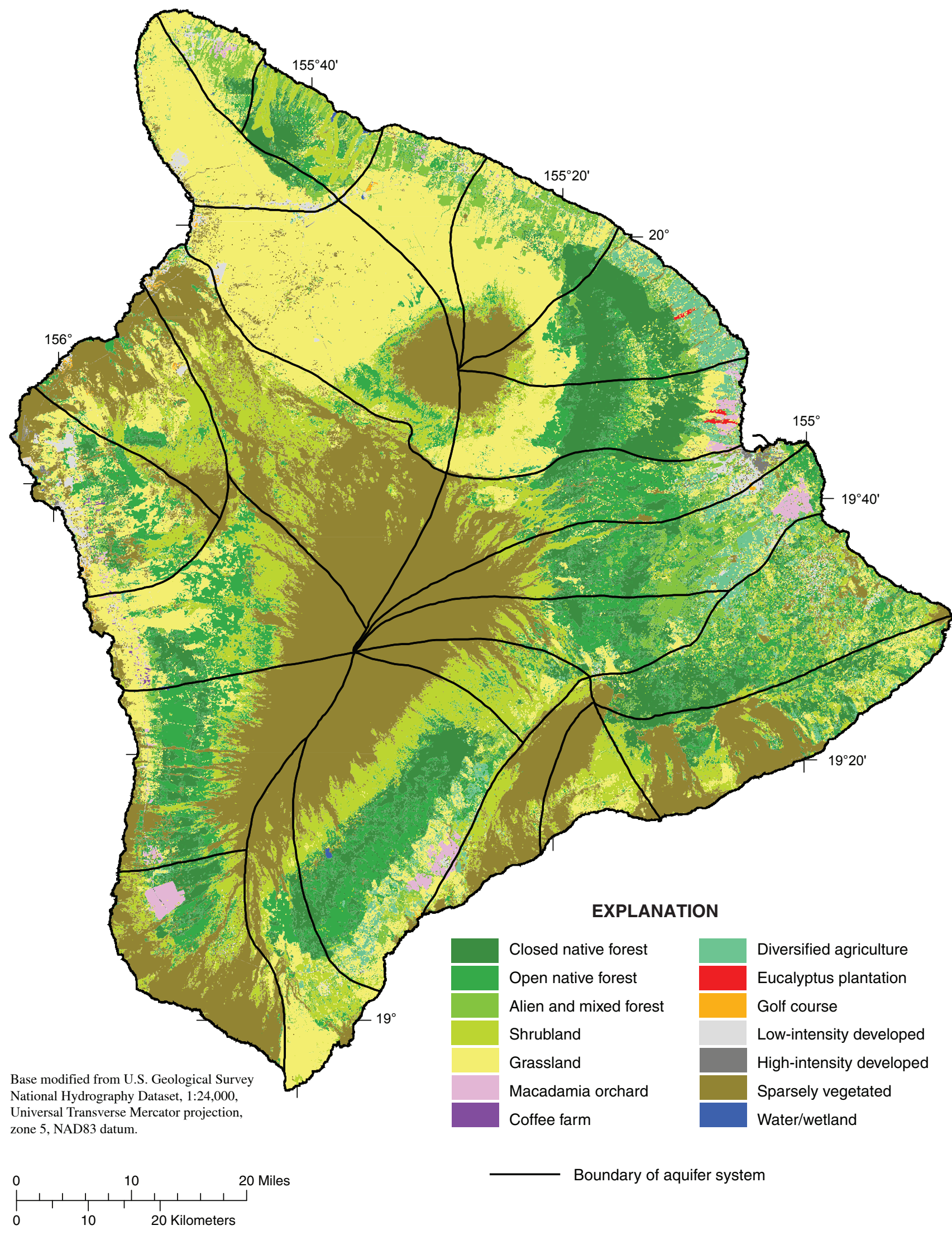

Figure 4. Land cover on the Island of Hawai'i (modified from U.S. Geological Survey, 2006). Coffee-farm, golfcourse, and water/wetland land covers are difficult to see at this scale. 
others (2008) described the ongoing invasion of native forest by Falcataria moluccana, Fraxinus uhdei, Hedychium gardnerianum, Morella faya, and Psidium cattleianum at five locations on Mauna Kea and Kîlauea. These invasions are fundamentally changing the hydrology of the island. For most of the 20th century, sugarcane cultivation dominated the coastal areas of windward Mauna Kea, southeastern Mauna Loa, and northern Kohala. Much of this land was native forest before being converted to agriculture. Since the demise of the sugarcane industry in the 1990s, former sugarcane lands that have not switched to diversified agriculture have become dominated by mostly alien grassland (U.S. Geological Survey, 2006). Along the leeward coast, from near Kawaihae to Captain Cook, urbanization is occurring at a rapid pace. Large-scale resorts that include hotels, condominiums, luxury houses, shopping centers, and golf courses are being developed, affecting large stretches of coastline.

\section{Water-Budget Model}

\section{Conceptual Model}

The daily water-budget model used here to estimate groundwater recharge is a "threshold-type" or "reservoir" model utilizing a variation of the Thornthwaite and Mather (1955) mass-balance procedure. The basic structure of the model is the same as that used for other recent U.S. Geological Survey (USGS) recharge studies in the Hawaiian Islands (Oki, 2002; Izuka and others, 2005; Engott and Vana, 2007), except that canopy evaporation in forests is explicitly considered in this model. Figure 5 displays the two generalized flow diagrams used in this study-one for nonforest land covers and one for forest land covers. Both conceptual models employ a plant-root zone reservoir. The forest model includes a second reservoir consisting of the forest canopy.

The volume of the plant-root zone reservoir is based on plant and soil properties. The model accounts for water entering, leaving, and being stored within the plant-root zone reservoir on a daily basis. At the end of a given day, if the volume of water entering the system exceeds the storage capacity of the plant-root zone reservoir, given the antecedent water content and water losses due to evapotranspiration (ET) processes, the reservoir overflows. This overflow is counted as groundwater recharge by the model.

The forest-canopy reservoir is not treated as a true reservoir in the model calculations, as the volume of water within the reservoir is not tracked. Instead, net precipitation, which is the output from the reservoir that becomes input to the plant-root zone reservoir, is calculated using a relation to fog interception and rainfall that is developed from results in published studies. Canopy evaporation is then calculated as the difference between the combined rainfall and fog interception volume and net precipitation.

\section{FOR NONFOREST LAND COVERS}

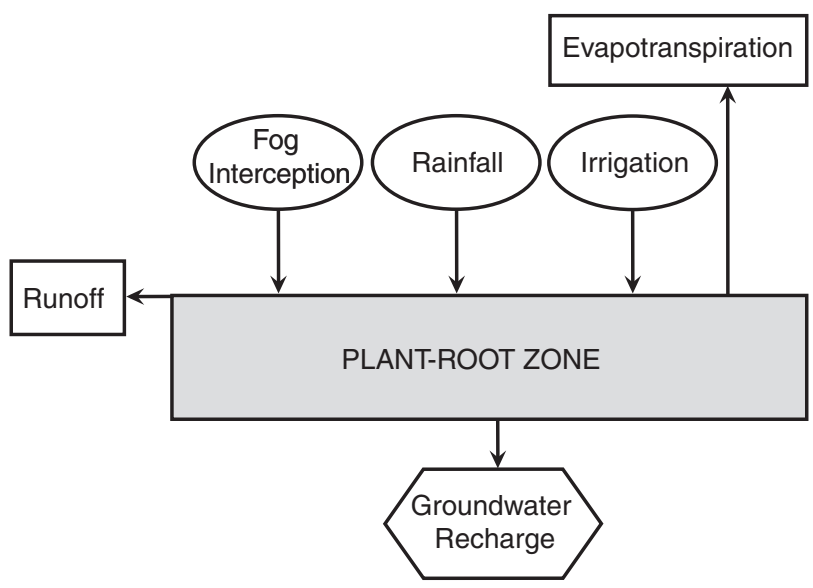

FOR FOREST LAND COVERS

(modified from McJannet and others, 2007)

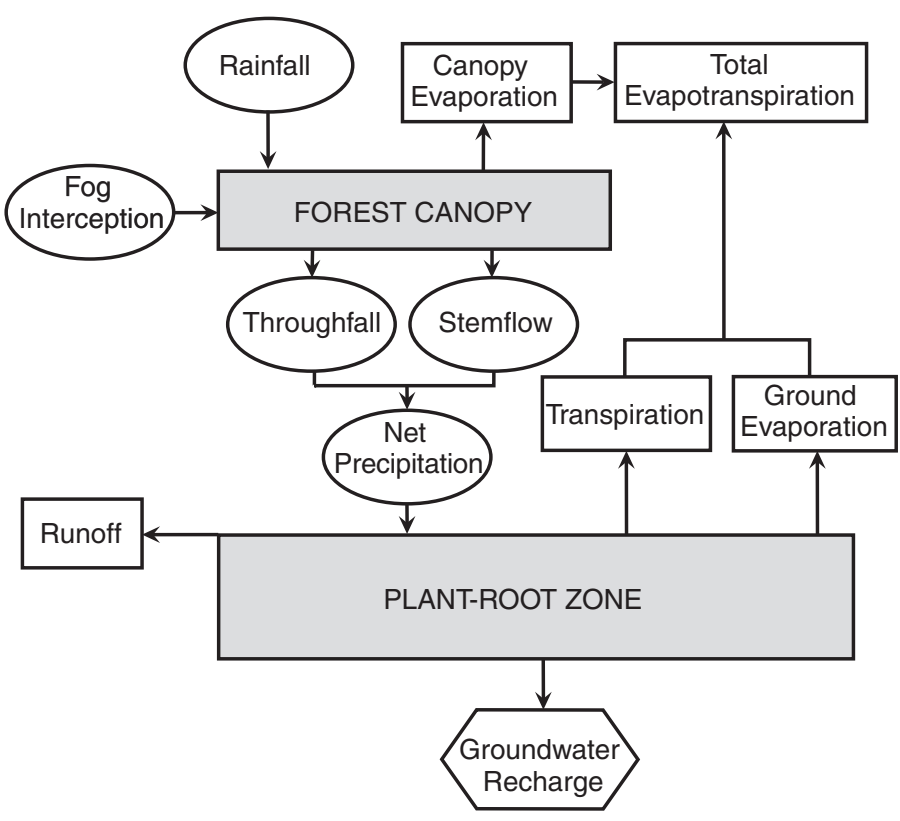

Figure 5. Generalized water-budget flow diagrams for both forest and nonforest land covers.

\section{Model Exclusions and Assumptions}

Several exclusions and assumptions are made to simplify the water-budget model. Recharge from streambed seepage is not explicitly considered, although direct runoff from each basin is modeled using best available information. Also, the variability of soil moisture with regard to depth within the soil root zone is not considered. In general, stationarity is assumed for climatological statistics. For example, the rainfall statistics computed for the period 1916-83 by Giambelluca and others 
(1986) and the pan-evaporation statistics computed using data from various time periods by Ekern and Chang (1985) are assumed to be representative of and valid for all time periods considered in the model, except where noted.

\section{Model Calculations}

Groundwater recharge for the Island of Hawai' $i$ was computed using the daily water-budget model and input data that quantify the spatial and temporal distribution of rainfall, fog interception, irrigation, evaporation, runoff, soil type, and land cover. Areas of homogeneous properties, termed "subareas," are generated by merging datasets that characterize the spatial and temporal distribution of rainfall, fog, irrigation, pan evaporation, runoff, soil type, and land cover in a geographical information system (GIS). For each subarea, recharge is calculated by the water-budget model. At the end of a simulation period, results for the subareas are summed over larger areas of interest, which can include entire aquifer systems. In the water-budget model for the Island of Hawai' $i$ there are 467,805 subareas with an average area of 5.51 acres.

For each subarea at the start of each day, the model calculates an interim moisture storage. Interim moisture storage is the amount of water that enters the plant-root zone for the current day plus the amount of water already in the zone from the previous day. For the first day of the simulation, a value for the amount of water already in the zone from the previous day (initial soil moisture) is selected by the user. For nonforest subareas, interim moisture storage is given by the equation

$$
X_{i}=P_{i}+F_{i}+I_{i}+W_{i}-R_{i}+S_{i-1}
$$

where

$$
\begin{aligned}
X_{i}= & \text { interim moisture storage for current day }[\mathrm{L}], \\
P_{i}= & \text { rainfall for current day }[\mathrm{L}], \\
F_{i}= & \text { fog interception for current day }[\mathrm{L}], \\
I_{i}= & \text { irrigation for current day }[\mathrm{L}], \\
W_{i}= & \text { excess water from the impervious fraction of an } \\
& \text { urban area distributed over the pervious fraction } \\
& {[\mathrm{L}], } \\
R_{i}= & \text { runoff for current day }[\mathrm{L}], \\
S_{i-1}= & \text { moisture storage at the end of the previous day } \\
& (i-1)[\mathrm{L}], \text { and } \\
i= & \text { subscript designating current day. }
\end{aligned}
$$

For forest subareas, interim moisture storage is given by the equation

$$
X_{i}=(N P)_{i}-R_{i}+S_{i-1}
$$

where

$$
(N P)_{i}=\text { net precipitation for current day [L], }
$$

For forest subareas, net precipitation is computed as the sum of rainfall and fog interception less canopy evaporation, which is the amount of water from rainfall and fog that collects on the leaves, stems, and trunks of trees and subsequently evaporates. The equation is where

$$
(N P)_{i}=P_{i}+F_{i}-(C E)_{i}
$$

$$
(C E)_{i}=\text { canopy evaporation }[\mathrm{L}] .
$$

For urbanized subareas, which in this study include the land-cover categories low-intensity developed and high-intensity developed (fig. 4), the interim equation includes the factor $W_{i}$, which is a function of the fraction of urban subareas that are estimated to be impervious (see equation 1a). In nonurban subareas where there is no impervious fraction, $W_{i}$ is zero. Urbanized subareas are assigned a fraction $(z)$ that is impervious. This fraction is used to separate, from the total rain that falls in an urbanized subarea, a depth of water that is treated computationally as though it fell on an impervious surface. Based on this impervious water fraction, some water is subtracted to account for direct evaporation. The remainder of the water $\left(W_{i}\right)$ is added to the water budget of the pervious fraction of the model subarea. Thus, for the pervious fraction of an urban subarea, the total daily water input includes an excess of water from the impervious fraction.

For an urbanized model subarea, excess water, $W_{i}$, and water storage (ponded water) on the surface of impervious areas were determined using the following conditions:

$$
X 1_{i}=P_{i}-R_{i}+T_{i-1},
$$

$$
\begin{aligned}
& \text { for } X 1_{i} \leq N, \\
& \qquad W_{i}=0 \text {, and } X 2_{i}=X 1_{i}, \\
& \text { for } X 1_{i}>N, \\
& \quad W_{i}=\left(X 1_{i}-N\right) z /(1-z) \text {, and } X 2_{i}=N,
\end{aligned}
$$

where

$$
\begin{aligned}
& X 1_{i}=\text { first interim moisture storage on the surface of } \\
& \text { impervious area for current day [L], } \\
& X 2_{i}=\text { second interim moisture storage on the surface of } \\
& \text { impervious area for current day [L], } \\
& T_{i-1}=\text { water storage (ponded water) on the surface of } \\
& \text { impervious area at the end of the previous day } \\
& (i-1)[\mathrm{L}] \text {, } \\
& N=\text { rainfall interception capacity (maximum amount } \\
& \text { of water storage on the surface of impervious } \\
& \text { area) [L], and } \\
& z=\text { fraction of area that is impervious [dimensionless]. }
\end{aligned}
$$

The water storage on the surface of the impervious area at the end of the current day, $T_{i}$, is determined from the equation

$$
\begin{aligned}
\text { for } X 2_{i}> & V_{i}, \\
& T_{i}=X 2_{i}-V_{i}, \text { and } \\
\text { for } X 2_{i} \leq & V_{i}, \\
& T_{i}=0,
\end{aligned}
$$

where

$$
V_{i}=\text { pan evaporation for current day }[\mathrm{L}] .
$$

The next step in the water-budget computation is to determine the amount of water that will be removed from the plant-root zone by ET. Actual ET is a function of potential ET and interim moisture $\left(X_{i}\right)$. A vegetated surface loses water to 
the atmosphere at the potential-ET rate if sufficient water is available. At all sites, potential ET was assumed to be equal to pan evaporation multiplied by an appropriate vegetation factor, termed a pan coefficient. For moisture contents greater than or equal to a threshold value, $C_{i}$, the rate of ET was assumed to be equal to the potential-ET rate. For moisture contents less than $C_{i}$, ET was assumed to occur at a reduced rate that declines linearly with soil-moisture content:

$$
\begin{aligned}
& \text { for } \mathrm{S} \geq C_{i,}, \\
& \qquad E=(P E)_{i}, \text { and } \\
& \text { for } S<C_{i} \text { and } C_{i}>0, \\
& \qquad E=S \times(P E)_{i} / C_{i},
\end{aligned}
$$

where

$$
E=\text { instantaneous rate of evapotranspiration }[\mathrm{L} / \mathrm{T}] \text {, }
$$$$
(P E)_{i}=\text { potential-evapotranspiration rate }
$$
for the current day $[\mathrm{L} / \mathrm{T}]$,

$S=$ instantaneous moisture storage [L], and

$C_{i}=$ threshold moisture storage for the current day below which evapotranspiration is less than the potential-evapotranspiration rate [L].

The threshold moisture storage, $C_{i}$, was estimated using the model of Allen and others (1998) for soil moisture. In this model, a depletion fraction, $p$, which ranges from 0 to 1 , is defined as the fraction of maximum moisture storage that can be depleted from the root zone before moisture stress causes a reduction in ET. The threshold moisture, $C_{i}$, is estimated from $p$ by the equation

$$
C_{i}=(1-p) \times S_{m},
$$

where

$S_{m}=$ moisture-storage capacity of the plant-root zone [L].

The moisture-storage capacity of the plant-root zone, $S_{m}$, expressed as a depth of water, is equal to the plant root depth multiplied by the available water capacity of the soil, $\phi$. Available water capacity is the difference between the volumetric field-capacity moisture content and the volumetric wiltingpoint moisture content:

where

$$
S_{m}=D \times \phi,
$$

$$
\begin{aligned}
D= & \text { plant root depth }[\mathrm{L}], \\
\phi= & \theta_{f c}-\theta_{w p}\left[\mathrm{~L}^{3} / \mathrm{L}^{3}\right], \\
\theta_{f c}= & \text { volumetric field-capacity moisture } \\
& \text { content }\left[\mathrm{L}^{3} / \mathrm{L}^{3}\right], \text { and } \\
\theta_{w p}= & \text { volumetric wilting-point moisture } \\
& \text { content }\left[\mathrm{L}^{3} / \mathrm{L}^{3}\right] .
\end{aligned}
$$

Values for $p$ depend on vegetation type and can be adjusted to reflect different potential-ET rates. In this study, $p$ values were based on data in Allen and others (1998).

In the water-budget model, the ET rate from the plantroot zone may be (1) equal to the potential-ET rate for part of the day and less than the potential-ET rate for the remainder of the day, (2) equal to the potential-ET rate for the entire day, or (3) less than the potential-ET rate for the entire day. The total ET from the plant-root zone during a day is a function of the potential-ET rate $\left((P E)_{i}\right)$, interim moisture storage $\left(X_{i}\right)$, and threshold moisture content $\left(C_{i}\right)$. By recognizing that $E=-\mathrm{d} S / \mathrm{d} t$, the total depth of water removed by ET during a day, $E_{i}$, was determined as follows:

$$
\begin{aligned}
& \text { for } X_{i}>C_{i} \text { and } C_{i}>0, \\
& \qquad E_{i}=(P E)_{i} t_{i}+C_{i}\left\{1-\exp \left[-(P E)_{i}\left(1-t_{i}\right) / C_{i}\right]\right\}, \\
& \text { for } X_{i}>C_{i} \text { and } C_{i}=0, \\
& \qquad E_{i}=(P E)_{i} t_{i}, \\
& \text { for } X_{i} \leq C_{i} \text { and } C_{i}>0 \\
& \\
& E_{i}=X_{i}\left\{1-\exp \left[-(P E)_{i} / C_{i}\right]\right\},
\end{aligned}
$$

and

$$
\begin{gathered}
\text { for } X_{i}=C_{i} \text {, and } C_{i}=0, \\
E_{i}=0,
\end{gathered}
$$

where

$$
E_{i}=\text { evapotranspiration from the plant-root zone }
$$
during the day [L],

$t_{i}=$ time during which moisture storage is above $C_{i}$ [T]. It ranges from 0 to 1 day and is computed as follows:

$$
\begin{aligned}
\text { for }\left(X_{i}-C_{i}\right)<(P E)_{i}(1 \text { day }) \\
t_{i}=\left(X_{i}-C_{i}\right) /(P E)_{i},
\end{aligned}
$$

and

$$
\begin{gathered}
\text { for }\left(X_{i}-C_{i}\right) \geq(P E)_{i}(1 \text { day }), \\
t_{i}=1
\end{gathered}
$$

After accounting for runoff (equation 1a or 1b), ET from the plant-root zone for a given day was subtracted from the interim moisture storage, and any moisture remaining above the maximum moisture storage was assumed to be recharge. The daily rate of direct recharge from anthropogenic sources is also added to daily recharge at this point. Recharge and moisture storage at the end of a given day were assigned according to the following conditions:

$$
\text { for } \begin{aligned}
X_{i}-E_{i} \leq S_{m}, Q_{i} & =D R, \text { and } \\
S_{i} & =X_{i}-E_{i},
\end{aligned}
$$

and

$$
\text { for } \begin{aligned}
X_{i}-E_{i}>S_{m}, Q_{i} & =\left(X_{i}-E_{i}-S_{m}\right)+D R, \text { and } \\
S_{i} & =S_{m},
\end{aligned}
$$

where

$$
\begin{aligned}
Q_{i}= & \text { groundwater recharge during the day }[\mathrm{L}], \text { and } \\
S_{i}= & \text { moisture storage at the end of the current day }(i) \\
& {[\mathrm{L}], \text { and } } \\
D R= & \text { daily rate of direct recharge }[\mathrm{L}] \text { (a constant). }
\end{aligned}
$$

Moisture storage at the end of the current day, expressed as a depth of water, is equal to the root depth multiplied by the difference between the volumetric soil-moisture content within the root zone at the end of the current day and the volumetric wilting-point moisture content:

where

$$
S_{i}=D \times\left(\theta_{i}-\theta_{w p}\right)
$$

$$
\theta_{i}=\text { volumetric soil-moisture content at the end of }
$$
the current day, $i,\left[\mathrm{~L}^{3} / \mathrm{L}^{3}\right]$. 


\section{Model Input}

\section{Land-Cover Map}

The base land-cover map for this study is from the Hawai'i Gap Analysis Program (GAP) (U.S. Geological Survey, 2006). Modifications to the base map were performed in a geographic information system (GIS). Modifications included converting the map from a raster dataset to a vector dataset, combining features smaller than the minimum mapping unit area of 0.36 ha (U.S. Geological Survey, 2006) with adjoining features, and combining feature classes. Agricultural lands in GAP are not categorized into individual crops. Although agricultural land does not make up a major part of the island, distinguishing between crops is important for water-budget calculations. Agricultural lands in the modified GAP landcover map were categorized by crop using digital satellite imagery, first-hand visual identification, and a digital land-use map (State of Hawai 'i, 1980). Golf courses are not explicitly identified in GAP. Similar to agricultural fields, golf courses do not make up a major part of the island. However, golfcourse irrigation can have an important effect on water-budget calculations. Features on the modified GAP land-cover map were classified as golf courses using digital satellite imagery in a GIS. Additionally, several recently constructed developments along the Kona coast were not identified on the GAP land-cover map. These were delineated on the modified GAP land-cover map on the basis of recent digital satellite imagery in a GIS. Finally, the Kohanaiki development, adjacent to Kaloko-Honokōhau National Historical Park and currently (2011) under construction, was superimposed on the modified GAP land-cover map using a digital map provided in a consultant report (Hunsaker and Associates Irvine, Inc., 2007) in a GIS.

The finalized land-cover map described here is termed "2008 land cover" throughout the remainder of this report. For the transient Kona-area submodel, the golf courses and developments were added chronologically to create land-cover maps representative of the several time periods. These maps are termed "1988 land cover," "1993 land cover," "1998 land cover," and "2003 land cover" throughout the remainder of this report.

\section{Rainfall}

\section{Mean Rainfall}

Maps of mean monthly rainfall for the Island of Hawai $\mathrm{i}$ (Giambelluca and others, 1986) were digitized and used to define the spatial and temporal distribution of rainfall. Figure 3 shows mean annual rainfall in the study area for the period 1916-83. In the model, areas between lines of equal monthly rainfall were assigned the average values of the bounding lines. To generate daily rainfall values for the model, 95 rain gages were selected on the basis of completeness of daily record and location. Thiessen polygons were used to spatially extrapolate the daily rainfall patterns indicated by the gages. Rainfall data were obtained from the National Climatic Data Center (NCDC), the Remote Automated Weather Station (RAWS) network, the Soil Climate Analysis Network (SCAN), the State of Hawai 'i Commission on Water Resources Management (CWRM), and the USGS.

Daily rainfall was synthesized by disaggregating the monthly rainfall values using the method of fragments (see, for example, Oki, 2002). The method creates a synthetic sequence of daily rainfall from monthly data by imposing the rainfall pattern from a rain gage with daily data. Fragments were created by dividing each daily rainfall measurement for a particular month by the total rainfall for that month. This created a set of fragments for that particular month in which the total number of fragments was equal to the number of days in the month. Fragment sets were created for every gage for every month in which complete daily rainfall measurements were available. Fragment sets were grouped by month of the year and by rain gage. The fragment set to be used for a given gage for a given month was selected randomly from among all available sets for that gage for that month of the year. Synthesized daily rainfall for a given month was created by multiplying total rainfall for that month by each fragment in the set, thereby providing daily rainfall, $P_{i}$, for equation $1 \mathrm{a}$ or $1 \mathrm{~b}$.

\section{Temporal Variability}

The interannual variability of rainfall was factored into the water-budget model to provide a more realistic estimation of long-term mean groundwater recharge. This was accomplished by running the water-budget model for a period of 25 years and by dividing the island into seven regions of similar rainfall characteristics, including rates, mechanisms (orographic, convective, and so forth), and seasonal patterns (fig. 6). For each region, data from one gage were used to represent how rainfall varied from year to year within that entire region. This gage was selected on the basis of completeness of record. Except for the region that includes gage 519412 on the northwestern side of the island (fig. 6), the 25-year period 1955-1979 was chosen as the period from which to generate the interannual variability of rainfall across the island. The rainfall records are very complete during this time period, owing to extensive cultivation of sugarcane. For the region that includes gage 519412, the period 1976-2000 was used instead, owing to the lack of available data before that time. For each gage, the observed annual rainfall for each year during the 25 -year time period was divided by the average annual rainfall for that time period (table 2), creating a series of 25 weighting factors for each rainfall region. Rainfall for a given month was calculated by multiplying the mean monthly value, based on Giambelluca and others (1986), by the weighting factor appropriate for the year and the rainfall region.

For the Kona water-budget submodel, which is designed to simulate historical recharge during the time period 19842008 , the observed monthly rainfall data for eight gages 


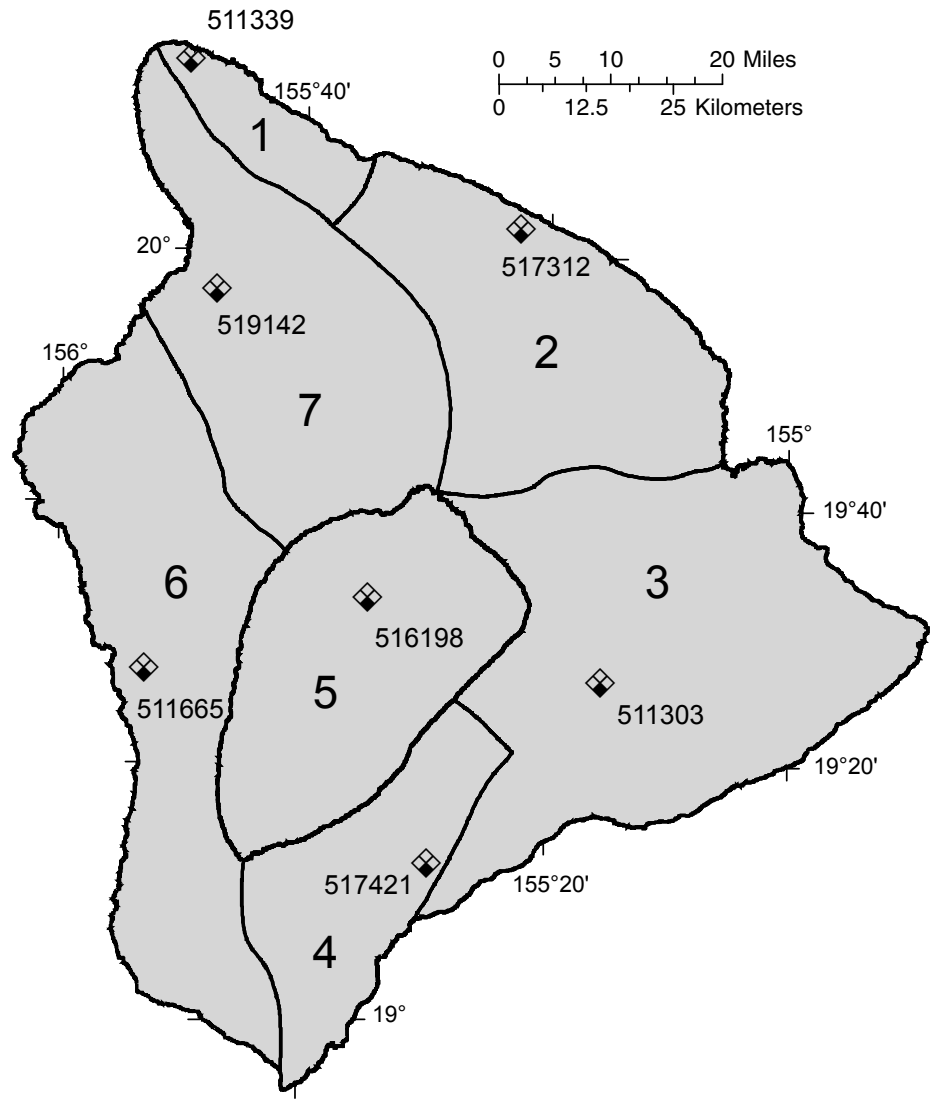

ISLAND OF HAWAI'I WATER-BUDGET

MODEL AREA

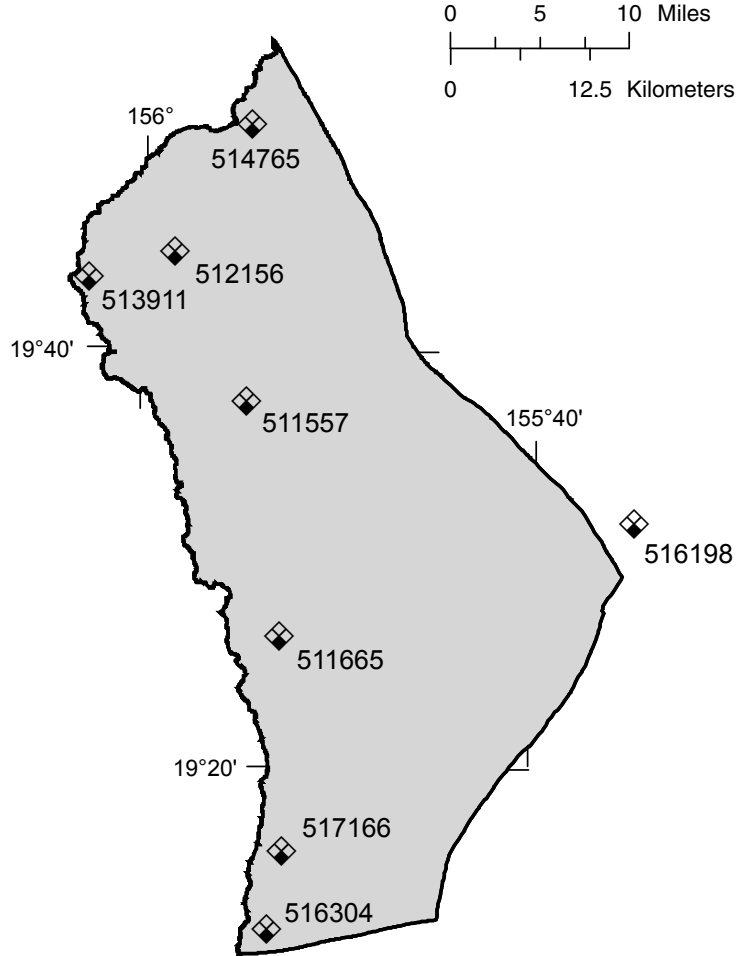

KONA WATER-BUDGET

SUBMODEL AREA

Figure 6. Rain-gage stations (diamonds with gage numbers) and the seven rainfall-variability zones used to simulate annual variability of rainfall in the Island of Hawai'i water-budget model and the rain-gage stations used to simulate monthly variability in the Kona water-budget submodel.

during this time period were used to simulate the historical rainfall pattern. Monthly weighting factors-ratios of observed monthly rainfall to mean monthly rainfall-were computed for the entire period, 1984-2008, for each gage. Mean monthly rainfall values for each gage were obtained from the Western Regional Climate Center (2009). Monthly weighting factors were applied spatially over the Kona study area using an inverse-distance-squared weighting method (Dirks and others, 1998). Rainfall for a given month was calculated by multiplying the mean monthly value from Giambelluca and others (1986) by the monthly weighting factor for that specific area. Daily rainfall was then calculated using the method of fragments, as described above.

\section{Fog Interception}

Fog is often persistent on the mid-elevation mountain slopes of Hawai ' $\mathrm{i}$, occurring during periods of onshore, upsloping winds favorable for orographic cloud formation.
Fog may be persistent at elevations as low as about 2,000 to $3,000 \mathrm{ft}$ on the Island of Hawai' $\mathrm{i}$ (Juvik and Ekern, 1978). Orographic cloud formation is often limited or capped by the base of the tradewind inversion, which commonly occurs between 5,000 and 10,000 ft (Giambelluca and Schroeder, 1998). This limitation on cloud formation hinders the growth of large raindrops and produces high ratios of fog to rain near or at the inversion-base elevation (Juvik and Ekern, 1978).

Above the base of the inversion, fog tends to dissipate quickly in the drier air regime.

Where fog is persistent, the interception of this moisture by vegetation has been shown to be a significant component of the water budget (Ekern, 1964; Juvik and Ekern, 1978; Juvik and others, 1993; Juvik and Nullet, 1995; Scholl and others, 2007). Fog interception occurs through the processes of turbulent diffusion and gravitational sedimentation of droplets onto vegetative surfaces, mainly leaves or needles (Bruijnzeel and others, 2005). Rates of fog interception are highly site dependent and influenced by both meteorological 


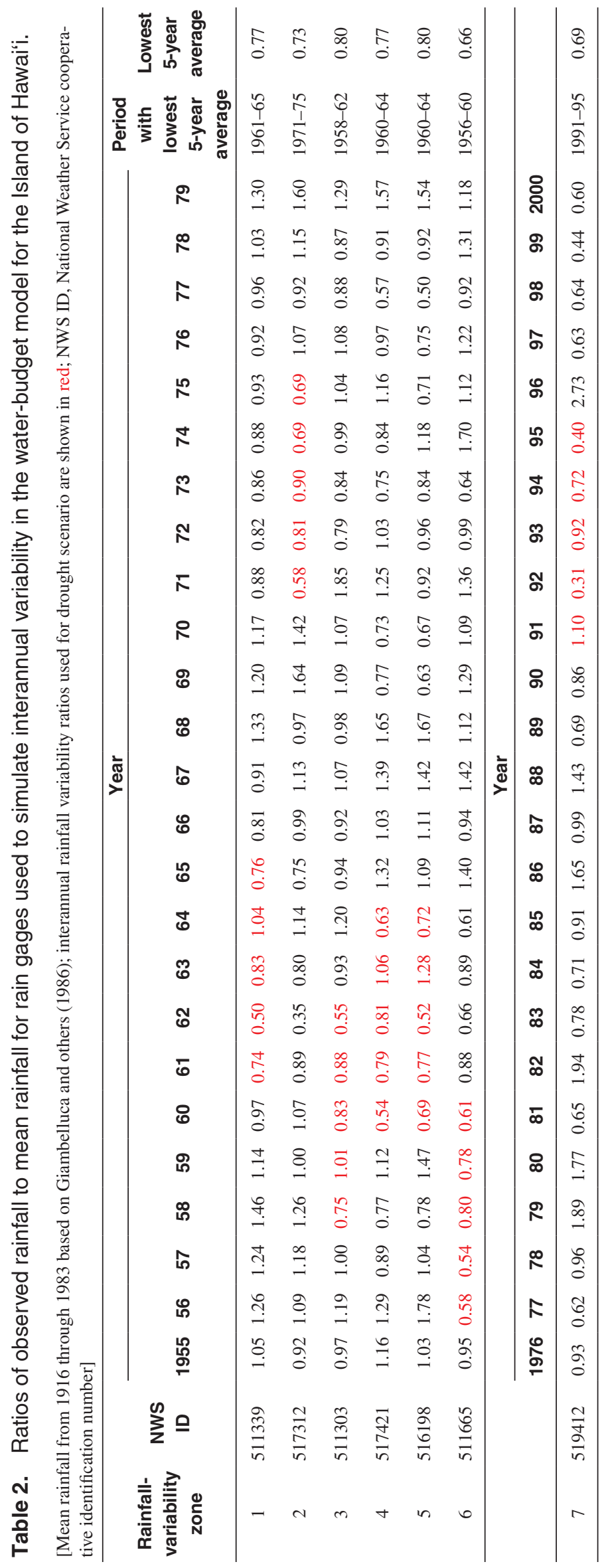


and biotic variables, including the duration and frequency of fog periods, wind speed and direction, liquid water content of fog, and structural characteristics of the forest, such as height, size, spatial pattern, and physical characteristics of leaves and epiphytes (Walmsley and others, 1996; Bruijnzeel and others, 2005; Villegas and others, 2007). The quantification of fog interception is a complex endeavor and is the subject of continuing research, both in Hawai' $i$ and worldwide.

In Hawai' $i$ water budgets, fog interception is often applied spatially within defined fog zones by using a relation to rainfall. One common method of estimating this relation is to compare the amount of cloud water collected in a mechanical fog gage to the amount of rainfall collected in a rain gage in the same area during concurrent periods. Juvik and Ekern (1978) developed relations between mechanical fog interception and rainfall for both the windward and leeward sides of Mauna Loa. These relations were used in the water-budget model. The windward Mauna Loa relation was spatially extended to include Kîlauea, southeastern Mauna Loa, windward Mauna Kea, and windward Kohala (fig. 7). The leeward Mauna Loa relation was spatially extended to include Hualālai. Data from a CWRM rain gage and mechanical fog gage at Kemole (fig. 3) were used to develop a relation of fog interception to rainfall that was used for leeward Mauna Kea. Table 3 displays the ratios of mechanical fog interception to rainfall used in the water-budget model. On the basis of the Juvik and Ekern (1978, p. 24) report, it was assumed that no fog interception occurs below an elevation of 2,500 ft. Also, it was assumed that no fog interception occurs on leeward Kohala.

Fog interception is primarily a phenomenon associated with trees and other tall vegetation, because the magnitude of fog interception is directly related to the height of the vegetated surface (Walmsley and others, 1996; Bruijnzeel and others, 2005). For this study, a fog-catch efficiency parameter (table 4) was introduced to account for the efficiency with which each land-cover category intercepts fog water. It is a ratio of the amount of fog intercepted by the land cover to the amount of fog intercepted by a mechanical collector. To calculate the total amount of fog interception for a given day, the following equation was used:

$$
F_{i}=P_{i} \times F I R \times F C E
$$

where

$$
\begin{aligned}
F_{i}= & \text { the amount of fog interception for day } i[\mathrm{~L}], \\
P_{i}= & \text { the amount of rainfall for day } i[\mathrm{~L}], \\
F I R= & \text { the fog interception-to-rainfall ratio } \\
& \text { [dimensionless], which is assumed to be } \\
& \text { constant within a month, and } \\
F C E= & \text { the fog-catch efficiency for the land cover } \\
& \text { [dimensionless]. }
\end{aligned}
$$

In the water-budget model, fog interception was considered hydrologically significant only for land covers with trees and shrubs (see figs. 4 and 7). Other land-cover categories did not receive fog interception in the water-budget calculations.
The fog-catch efficiency for native open forest, native closed forest, mixed forest, alien forest, and forest (eucalytptus) agriculture was set to 1 . The fog-catch efficiency for shrubland and coffee was set to 0.5 , to account for the shorter stature of these land covers compared to forest.

\section{Irrigation}

\section{Agricultural Irrigation}

Daily irrigation was applied to all agricultural land covers in the water-budget model except forest (eucalyptus) and fallow/grassland. Daily irrigation was similarly applied to the golf-course land cover. These irrigated areas total only about 3 percent of the island. Hence, the effect of irrigation on the regional water budget is small. However, the local effects of irrigation could be important. Irrigation was calculated as the difference between monthly potential ET and rainfall and was applied uniformly over each day in the month. This is similar to the approach used for a recent water budget of central and west Maui (Engott and Vana, 2007). Calculation is as follows:

and

$$
\text { for }(P E)_{m}-P_{m}>0, \quad I_{m}=\left((P E)_{m}-P_{m}\right) / d_{m} \text {, }
$$

$$
\text { for }(P E)_{m}-P_{m} \leq 0, \quad I_{m}=0 \text {, }
$$

where

$I_{m}=$ the amount of daily irrigation for month $m[\mathrm{~L}]$,

$P_{m}=$ the amount of rainfall for month $m$ [L],

$(P E)_{m}=$ the potential evapotranspiration for month $m$ (varies by land cover)

[L], and

$d_{m}=$ the number of days in month $m$ [dimensionless].

\section{Urban-Landscape Irrigation}

Daily irrigation was also applied to both the low-intensity and high-intensity developed land covers to simulate the watering of lawns and landscaped areas. This irrigation was also applied uniformly over each day of the month. Irrigation in these areas was applied at a rate 0.6 times the rate calculated using equation 14. The factor 0.6 is a calibration factor based on irrigation water use reported in the Water Use and Development Plan Update (County of Hawai 'i, 2006).

\section{Runoff}

In this study, "runoff" is synonymous with the term "direct runoff" and is defined as the fraction of rainfall that does not contribute to net moisture gain within the plant-root zone (fig. 5). Direct runoff consists of overland surface flow and interflow (water that flows in the shallow subsurface and is eventually discharged to a stream or other surface-water body).

To assist in runoff analysis, the Island of Hawai' $i$ was divided into runoff zones on the basis of climate, 


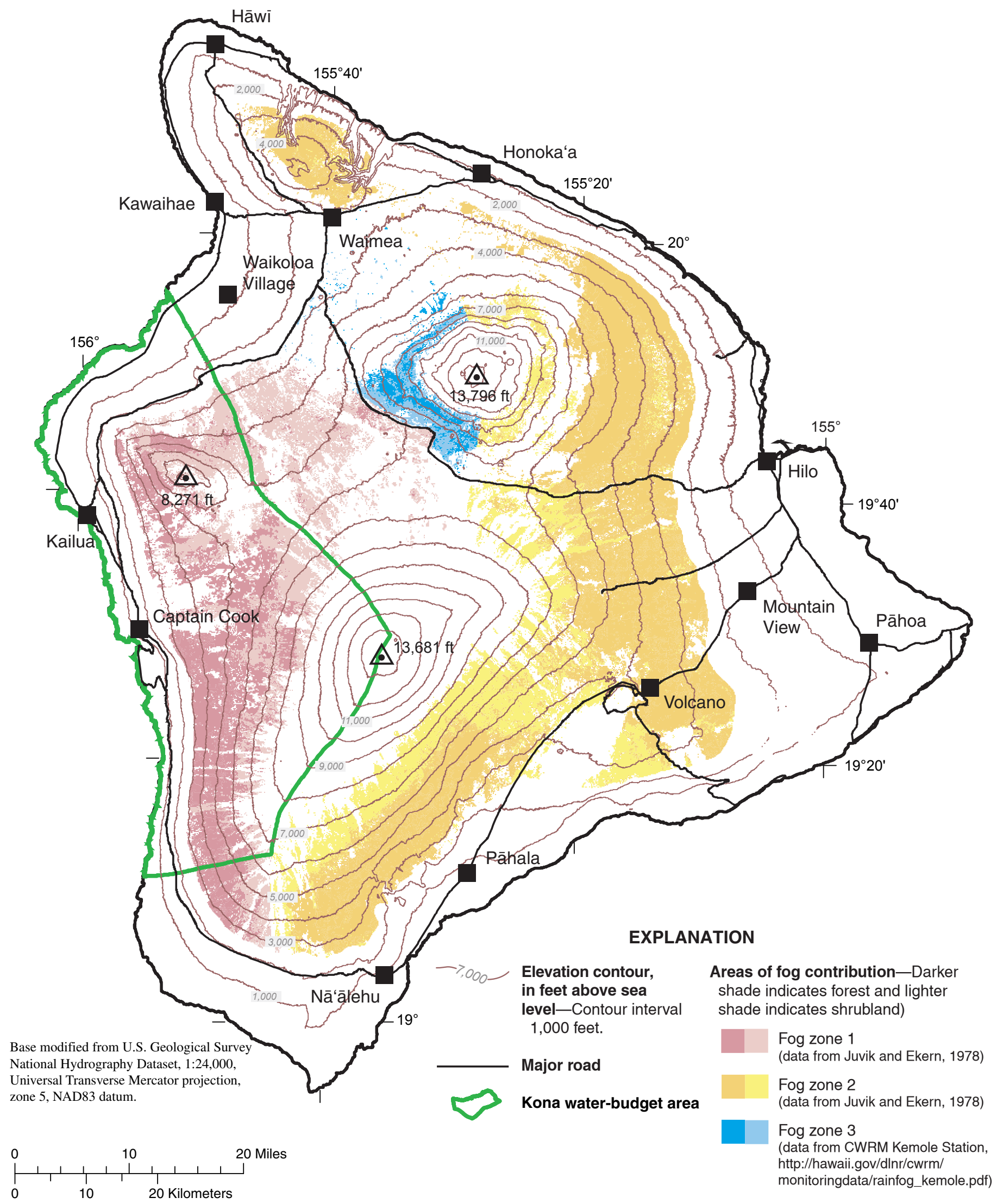

Figure 7. Areas of fog contribution to the water budget on the Island of Hawai'i. 
Table 3. Ratios of fog interception to rainfall used in the water-budget model for the Island of Hawai'i.

[See figure 7 for locations of fog zones; ft, feet above mean sea level]

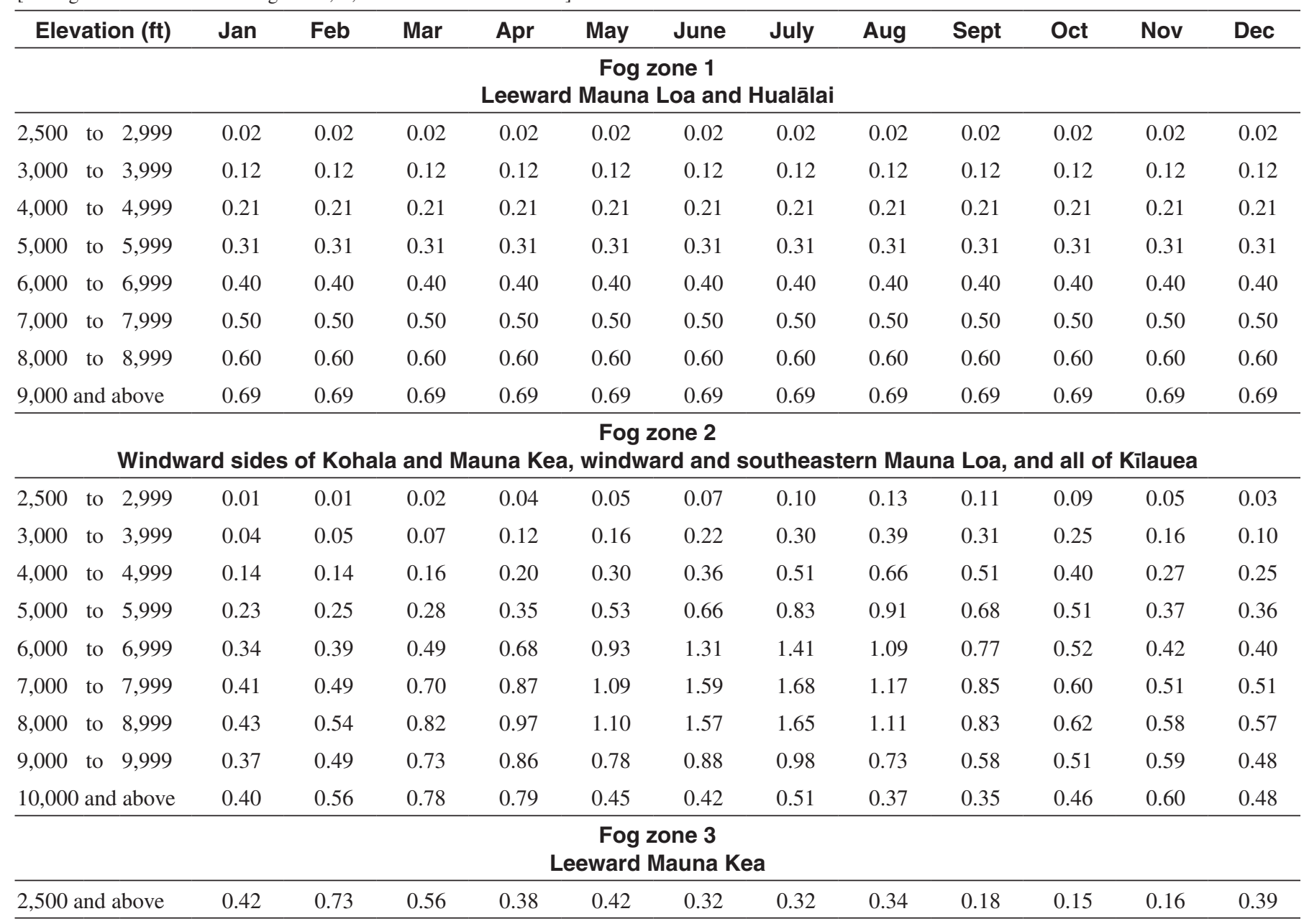

physiography, available data from stream-gaging stations, and previous water-budget studies. This approach is similar to that employed in water budgets by Shade (1995), Oki (2002), and Engott and Vana (2007). Each zone was assigned a runoff-torainfall ratio for each calendar month, and this ratio was applied over the entire zone. Ideally, runoff ratios are calculated on the basis of data from continuous-record stream-gaging stations with long periods of record. However, perennial streams are relatively few on the island, and continuous streamgage records generally are sporadic or nonexistent. Other sources or methods used for assigning monthly runoff ratios (in order of preference) were: (1) ratios for the same area from previously published reports, (2) ratios for comparable areas from previously published reports, (3) averaging of ratios from the same area or from comparable areas, or (4) estimation based on geomorphology and climate of the area.

\section{Runoff Zones}

The island was divided into 17 runoff zones (fig. 8). Runoff zones 1, 2, and 3 are on the windward side of Kohala
Mountain and are based on areas delineated and used in the water budgets by Shade (1995) and Oki (2002). Zone 1 is the area below the 400-ft elevation contour and west of Pololū Valley. Zone 2 is the area above the $400-\mathrm{ft}$ elevation contour and west of Pololū Valley. Zone 3 consists of Pololū and Waipiō Valleys and all the valleys between them. Abundant rainfall in this area, ranging from about $70 \mathrm{in} / \mathrm{yr}$ to $160 \mathrm{in} / \mathrm{yr}$, supports numerous perennial streams that have created deeply incised valleys.

Runoff zones 4 through 7 are on the windward side of Mauna Kea. Zone 4 is the area (1) below the 6,560-ft elevation contour, the typical base of the tradewind inversion and (2) having mean annual rainfall less than 118 in. Some streams in this area are perennial at lower elevations but intermittent at higher elevations. Zone 5 is the area that lies above the 6,560 -ft elevation contour, or the tree line as defined by the boundary between grassland and forested land covers, on the eastern side of Mauna Kea (fig. 4). The climate here is much drier than in other parts of windward Mauna Kea, hence less weathering and erosion of the land surface has occurred in this zone. For the remaining area of windward Mauna Kea, runoff 
Table 4. Land-cover parameters used in water-budget calculations for the Island of Hawai'i.

\begin{tabular}{|c|c|c|c|c|c|}
\hline Land-cover description & $\begin{array}{l}\text { Root depth } \\
\text { (inches) }\end{array}$ & $\begin{array}{l}\text { Pervious } \\
\text { fraction }\end{array}$ & $\begin{array}{c}\text { Depletion } \\
\text { fraction }\end{array}$ & Pan coefficient & $\begin{array}{l}\text { Fog-catch } \\
\text { efficiency }\end{array}$ \\
\hline Open native forest & 25 & 1 & 0.50 & $0.84^{\mathrm{c}}, 0.44^{\mathrm{d}}$ & 1 \\
\hline Closed native forest & 30 & 1 & 0.50 & $0.84^{\mathrm{c}}, 0.44^{\mathrm{d}}$ & 1 \\
\hline Alien forest & 60 & 1 & 0.50 & $1.68^{\mathrm{c}}, 0.88^{\mathrm{d}}$ & 1 \\
\hline Mixed native/alien forest & 45 & 1 & 0.50 & $1.68^{\mathrm{c}}, 0.88^{\mathrm{d}}$ & 1 \\
\hline Shrubland & 12 & 1 & 0.50 & 0.85 & 0.5 \\
\hline \multicolumn{6}{|l|}{ Agriculture } \\
\hline Macadamia & 60 & 1 & 0.50 & 0.77 & 1 \\
\hline Coffee & 48 & 1 & 0.40 & 0.81 & 0.5 \\
\hline Diversified & 12 & 1 & 0.35 & 0.85 & 0 \\
\hline Forest (eucalyptus) & 60 & 1 & 0.50 & 1.10 & 1 \\
\hline Fallow/Grassland & 39 & 1 & 0.60 & 0.81 & 0 \\
\hline Golf course & 30 & 1 & 0.50 & 0.72 & 0 \\
\hline Low-intensity developed & 12 & $0.8^{\mathrm{a}}$ & 0.50 & 1.00 & 0 \\
\hline High-intensity developed & 12 & $0.15^{\mathrm{b}}$ & 0.50 & 1.00 & 0 \\
\hline Grassland & 39 & 1 & 0.60 & 0.81 & 0 \\
\hline Sparsely vegetated & 5 & 1 & 0.50 & 1.00 & 0 \\
\hline Wetland vegetation & 6 & 1 & 0.50 & 1.00 & 0 \\
\hline Water body & 0 & 1 & 1.00 & 1.00 & 0 \\
\hline \multicolumn{6}{|c|}{ aValue is based on "residential" land cover in Engott and Vana (2007). } \\
\hline \multicolumn{6}{|c|}{ bValue is based on "industrial and commercial complexes" land cover in Engott and Vana (2007). } \\
\hline \multicolumn{6}{|c|}{$\begin{array}{l}{ }^{c} \text { Value used outside the fog zone to compute the combination of transpiration and ground evaporation. Canopy evaporation is } \\
\text { calculated separately. }\end{array}$} \\
\hline \multicolumn{6}{|c|}{$\begin{array}{l}{ }^{\mathrm{d}} \text { Value used inside the fog zone to compute the combination of transpiration and ground evaporation. Canopy evaporation is } \\
\text { calculated separately. }\end{array}$} \\
\hline
\end{tabular}

zones 6 and 7 were delineated on the basis of rainfall. In zone 6 , mean annual rainfall is greater than $118 \mathrm{in}$. and less than 157 in. In zone 7, mean annual rainfall is greater than 157 in. In zones 6 and 7, annual rainfall is the highest on the island, and numerous perennial streams exist, some of which have carved deep valleys.

Runoff zone 8 is the windward part of Mauna Loa below the 6,560-ft elevation contour. This area includes relatively young land surfaces, with some lava flows as recent as 1984 . Some streams exist owing to the high annual rainfall-as much as about $240 \mathrm{in} / \mathrm{yr}$. Runoff zone 9 includes the surface lavas of Killauea, which generally are the youngest on the island. The land surface is extremely porous, allowing for very little runoff, except during the most intense rainstorms. Runoff zone 10 is the southeastern side of Mauna Loa below the 6,560-ft elevation contour. Annual rainfall on this part of the island is quite high, ranging from about $49 \mathrm{in}$. to $138 \mathrm{in}$. Several streams have perennial reaches at elevations where rainfall is high and groundwater springs exist, but they are intermittent at lower and higher elevations where rainfall is less intense. Runoff zone 11 is the part of Mauna Loa that lies above the 6,560-ft elevation contour, the typical base of the tradewind inversion. The land surface in this area is relatively young, with some lava flows as recent as 1984, and the climate is very dry. The relatively unweathered lavas are extremely porous and not conducive to producing large amounts of runoff. Runoff zone 12 is the southwestern part of leeward Mauna Loa lying below the tradewind inversion, and runoff zone 13 includes the surface rocks of Hualālai. Some shallow watercourses exist on the relatively young surfaces of these two zones. However, despite encompassing areas in which mean annual rainfall exceeds 80 in., no perennial streams flow, according to USGS streamgage data. Runoff zone 14 is the northwestern part of leeward Mauna Loa. This area is dry, and the surface rocks are relatively unweathered. Only a few, ill-defined watercourses exist, and these likely flow only during periods of heavy rain.

Runoff zone 15 is leeward Mauna Kea, the driest area of the island. No perennial streams exist in this area, only a network of shallow valleys and intermittent streams. Runoff zones 16 and 17 are on the leeward side of Kohala Mountain. The leeward slope of Kohala Mountain has a very steep rainfall gradient. Annual rainfall at the coast is about 10 in. near Kawaihae, whereas annual rainfall at the crest is about 120 in., a difference of $110 \mathrm{in}$. over less than 7 miles. Zone 17 is the area of leeward Kohala where mean annual rainfall exceeds 60 in. In this zone, reaches of several streams flow perennially. 


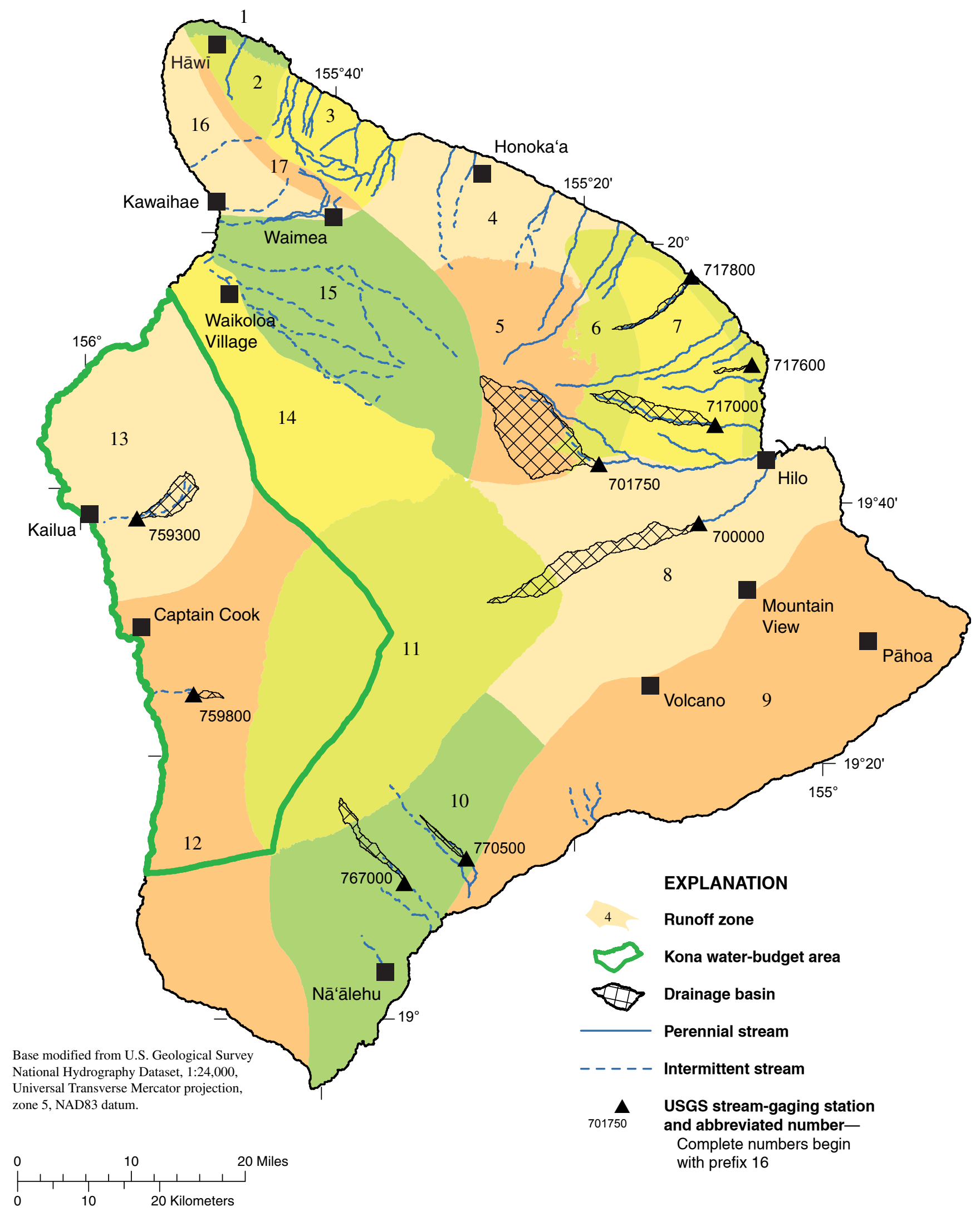

Figure 8. Runoff zones defined for the water-budget calculation on the Island of Hawai $i$. 
Flows in these streams diminish as they traverse zone 16, becoming intermittent before reaching the coast.

\section{Runoff-to-Rainfall Ratios}

Table 5 displays the monthly runoff-to-rainfall ratios assigned to each runoff zone for this water-budget model. It also summarizes the method or source used to assign the ratio. If runoff ratios were calculated using streamgage data, table 5 shows the gaging-station number, stream, drainage-basin area, number of days used in the hydrograph-separation program, and period of record.

In zones where streamgage data were used to calculate ratios, mean monthly direct runoff for a drainage basin was divided by the long-term mean monthly rainfall over that basin (Giambelluca and others, 1986). Although actual monthly rainfall during the periods of record of the streamgaging stations may differ from the long-term mean monthly rainfall, this method is assumed to be valid for stream-gaging stations with relatively long periods of record and is consistent with other recent water-budget studies in the Hawaiian Islands (for example, Izuka and others, 2005; Engott and Vana, 2007). For this water-budget model, two drainage basins, Ālia (16717600) and Wai 'aha (16759300) (fig. 8), had streamgaging stations with periods of record deemed too short for the above assumption to hold. Ālia Stream had only 10 years of record and Wai 'aha Stream only 11 years (table 5). For these basins, rainfall data from a nearby rain gage concurrent with the streamflow data were used instead of the long-term mean. For Ālia Stream, NWS\# 511960 was used, and for Wai 'aha, NWS\# 511557 was used.

\section{Computation of Runoff from Streamgage Data}

Streamflow is composed of both direct runoff and base flow, which is groundwater that discharges into the stream. To separate the base-flow and direct-runoff components, the hydrograph-separation program of Wahl and Wahl (1995) was used. This computerized method removes much of the subjectivity associated with manual hydrograph-separation techniques, and it provides repeatable results if the two input parameters required by the method are held constant. The program is commonly used by the USGS in Hawai' $i$ (see for example, Fontaine, 2003; Izuka and others, 2005; and Engott and Vana, 2007). In the method, the two parameters that must be input are $N$ (number of days) and $f$ (turning-point test factor). The separation method divides the daily streamflow data into distinct, nonoverlapping periods, each $N$ days long, and determines the minimum flow in each period. The program computes $f$ times the central minimum and compares that to the adjacent minimums. If $f$ times the central minimum is less than the adjacent minimums, then the central minimum is made a pivot (or turning point) on the base-flow hydrograph. Straight lines drawn on semilogarithmic paper between turning-point discharge plotted versus the central time of the corresponding period defines the base-flow hydrograph. The recommended value of $f, 0.9$ (Wahl and Wahl, 1995), was used for all base-flow separations. Conceptually, the variable $N$ represents the number of days following a storm before direct runoff generally ceases (Fontaine, 2003). $N$ is determined separately for each stream-gaging station. To determine $N$ for each stream-gaging station, base flow was first estimated for each value of $N$ between 1 and 10 days. The ratio of base flow to total flow during the time period of $N$ days, or base-flow index, was then plotted against $N$. As the value for $N$ increases from 1 , estimated base flow declines sharply because the portion of direct runoff in the total flow is reduced as the effect of storms dissipate during the larger time period. At a critical value of $N$, the portion of direct runoff will be negligible and estimated base flow will drop only slightly, becoming essentially linear with increasing $N$. This critical $N$ value was then used to estimate base flow for the stream-gaging station being analyzed (table 5). Hydrograph separation was not used for $\mathrm{Pa}$ ' $\mathrm{au}$ ' $\mathrm{au}$ and Ninole Streams in runoff zone 10 because the base-flow component of streamflow is negligible in both streams. For runoff zone 10, the ratio of runoff to rainfall was calculated using total flow.

\section{Evapotranspiration}

Evapotranspiration (ET) is a collective term for all of the evaporative processes occurring in a plant-soil system. These processes can be grouped into three main types: (1) canopy evaporation, which is evaporation of intercepted rain and fog from the surface of vegetation; (2) ground evaporation, which is evaporation from the soil surface and overlying litter and mulch layers; and (3) transpiration, the process by which soil moisture taken up by vegetation is eventually evaporated as it exits at plant pores (Viessman and Lewis, 2003, p. 143). These processes are difficult to quantify individually and are commonly combined together in water budgets. Water budgets for Hawai ' $i$, including all of those listed in table 1, have treated ET in this manner (for example, Giambelluca, 1983; Izuka and others, 2005; and Engott and Vana, 2007). A more rigorous treatment of ET may be appropriate for some areas because ET processes tend to operate on much different time scales and vary in relative importance according to prevailing meteorological conditions and land-cover setting. Canopy and ground evaporation operate on the order of hours, whereas transpiration operates on the order of weeks or longer, depending on soil depth (Savenije, 2004).

Canopy evaporation can be very important in forests. Because of the height of trees, turbulent diffusion is much more efficient at removing intercepted water from forests than from other land-cover types, and this enhanced rate of evaporation from wet canopy makes realistic estimates of ET from forests possible only if transpiration and canopy evaporation are evaluated separately (Shuttleworth, 1993). In this study, ET in forests is calculated by separately estimating 


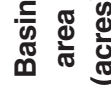

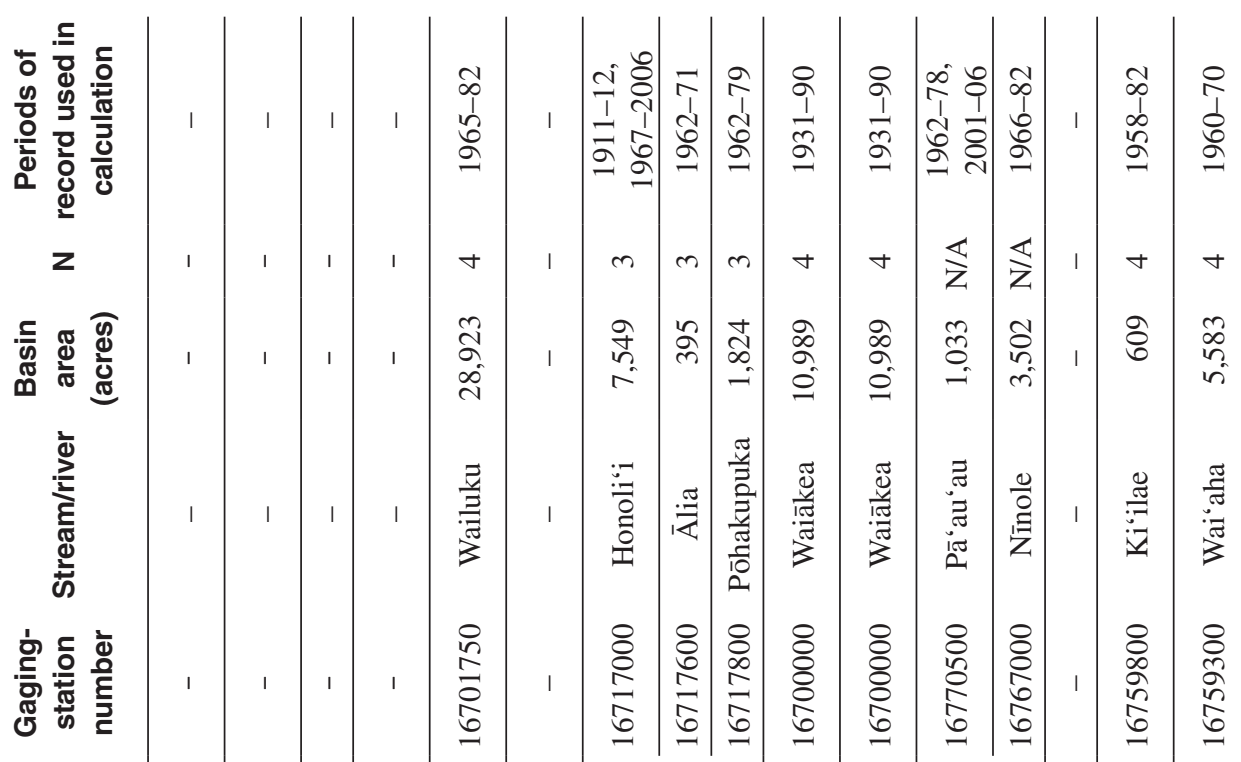

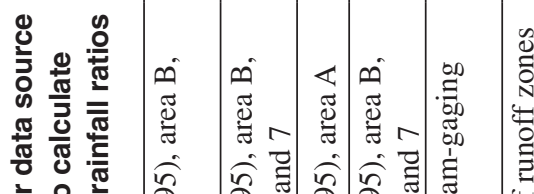

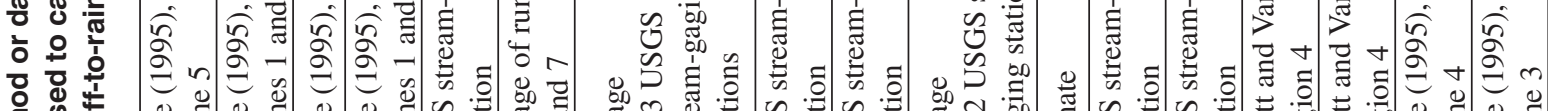

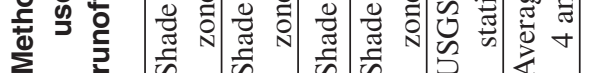
胥

ग)

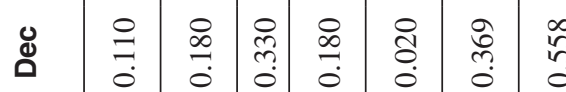

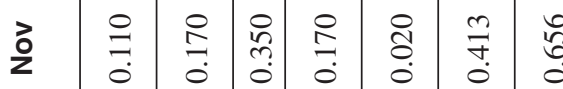

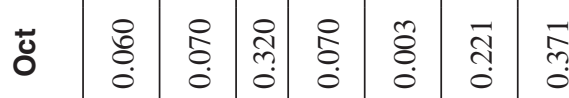

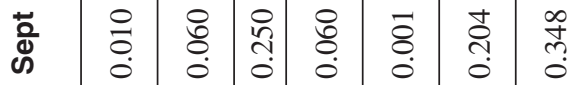

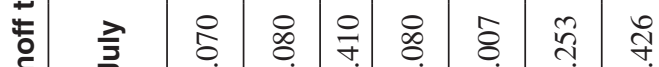


canopy evaporation and combined ground evaporation and transpiration. These two terms are then added together to yield a total ET rate. For all other land covers, ET is calculated using a more traditional approach, commonly used in agricultural practice and other water budgets for Hawai 'i, in which no separate estimates of canopy evaporation and combined ground evaporation and transpiration are made. The concept of potential ET, combined with soil-moisture limiting, is used to estimate ground evaporation and transpiration in forests and total ET for all other land covers. Canopy evaporation in forests is estimated using data from published studies.

\section{Canopy Evaporation and Net Precipitation}

As rain falls on a vegetated surface, a fraction of the droplets will strike and collect on the leaves, trunks, or stems of the vegetation in a process known as canopy interception. Additional moisture from fog interception may also enhance the volume of this collected water, which commonly is called "canopy storage." Canopy storage is partitioned into three fractions: (1) that which remains on the vegetation and is evaporated after or during rainfall, called "canopy evaporation" in this study; (2) that which flows to the ground along trunks or stems, commonly called "stemflow;" and (3) that which drips from the canopy and falls to the ground between the various components of the vegetation (Crockford and Richardson, 2000). The fraction of rain that does not contact vegetation on the way to the ground combined with the fraction described in (3) commonly is called "throughfall." The amount of water that reaches the soil surface, commonly called "net precipitation," is the sum of throughfall and stemflow. Canopy interception occurs in all vegetated land covers, but research primarily has been limited to forests. Direct measurements of canopy evaporation are very difficult to obtain and rarely attempted. Instead, it is far more common for researchers to collect net precipitation on the floor of a forest, beneath the canopy, and compare it to rainfall collected contemporaneously above the forest canopy or in a nearby open field. Therefore, net precipitation commonly is reported as a percentage of rainfall, regardless of whether or not fog interception is occurring in the forest. In areas where fog interception occurs, it is possible for net precipitation to be greater than 100 percent of rainfall.

For the water-budget model, net precipitation in forests was estimated using published studies listed on figure 9. Nearly one-half of the sites investigated in these studies are in the Hawaiian Islands -17 of 36 . The rest of the sites are in similar tropical locations. For forests outside of the fog zone (see figure 7), the average net-precipitation value of 29 sites, 73.45 percent of rainfall, was used, For forests in the fog zone, a linear regression was applied to net-precipitation and fog-interception data from the published studies (figure 9). For the point on the graph where fog interception equals zero (the y-intercept), the aforementioned average net-precipitation value of the 29 nonfog forest sites was used. The regression line was forced through this value. As expected, net precipitation increases with increasing fog interception. The linear relation is strong, as shown by a coefficient of determination $\left(\mathrm{R}^{2}\right)$ of 0.895 . However, there is a large gap in the data between the site with the highest fog-interception and that with the second highest. More data from sites where fog interception is between about $30 \mathrm{in} / \mathrm{yr}$ and $90 \mathrm{in} / \mathrm{yr}$ would increase confidence in the regression.

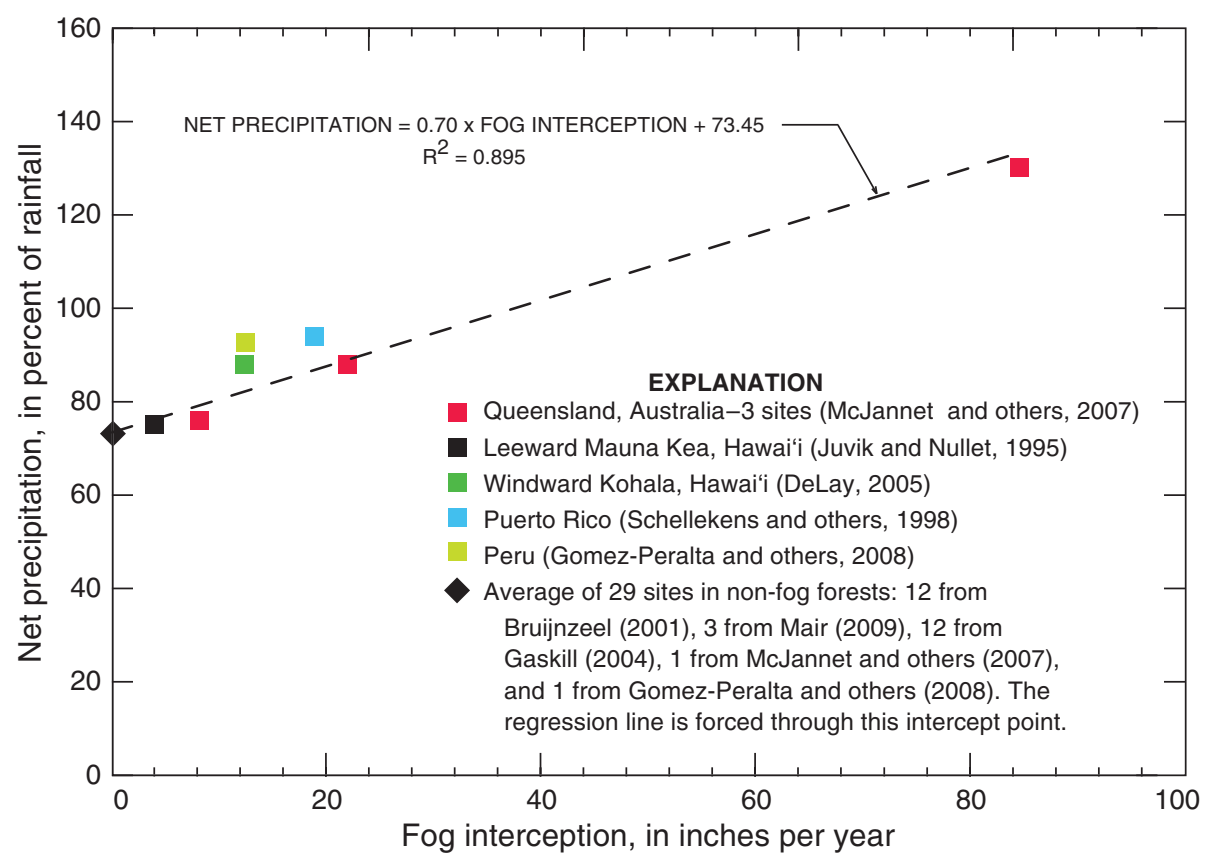

Figure 9. Analysis of the linear relation between net precipitation and fog interception in forests, based on data from studies in the Hawaiian Islands and similar tropical locations around the world. 


\section{Potential Evapotranspiration}

The maximum rate at which water can be removed from the plant-root zone by ET, if soil-moisture is nonlimiting, is termed "potential ET" (Giambelluca, 1983). The actual rate of ET becomes less than the potential rate with the onset of soil-moisture stress. As the soil dries, capillary and adsorptive forces bind the remaining water to the soil matrix more strongly, reducing water flow to roots. Soil-moisture stress occurs when the decreasing flow of water to the root system induces a response in the plant to slow down transpiration and prevent desiccation. The threshold moisture content at which a plant begins to react to soil drying varies with the type of plant. The actual rate of ET is a function of potential ET, soil-moisture content, and threshold-moisture content (see equation 9).

Potential evapotranspiration is controlled by prevailing atmospheric conditions (solar radiation, air temperature, humidity, and wind) and land-cover characteristics (reflectance, roughness, and plant physiology) (Giambelluca, 1983). Potential-ET data for Hawai 'i are fairly sparse; however, a significant amount of pan-evaporation data has been collected over many years by sugar plantations. Measurements of pan evaporation, although highly correlated with atmospheric conditions, are poorly correlated with land-cover characteristics. To account for land-cover characteristics, previous studies developed pan coefficients for Hawai'i based on vegetative cover (Ekern and Chang, 1985; Oki, 2002, Izuka and others 2005, Engott and Vana, 2007). A pan coefficient is an empirically derived ratio of potential ET to pan evaporation. In this study, potential ET for an area with a particular land cover is estimated by multiplying pan evaporation for the area by the appropriate pan coefficient.

\section{Pan Evaporation}

Mean rates of pan evaporation vary across the island according to location and time of year. To accommodate this variability, the study area was divided into pan-evaporation zones (pan zones) on the basis of (1) the mean annual rate of pan evaporation, (2) the monthly variability of pan evaporation, and (3) the source of data for monthly variability (fig. 10). Mean annual pan evaporation was derived from the map by Ekern and Chang (1985). In the model, areas between lines of equal pan evaporation were assigned the average values of the bounding lines.

To estimate monthly variability in each zone, ratios of monthly to annual pan evaporation were computed (table 6). Mean monthly pan-evaporation data (Ekern and Chang, 1985) for pan-evaporation stations within each zone were used. For pan zones in which pan-evaporation data were unavailable, alternate methods of estimating monthly variability were used. For pan zone 1, solar radiation data were used as a proxy for pan evaporation, because pan evaporation is well correlated with solar radiation (Ekern and Chang, 1985; Bean and others, 1994). For pan zone 6, Penman-Monteith evaporation from Juvik and Nullet (1994) calculated for a station at 1,130 m (3,707 ft.) on windward Mauna Loa was used. For pan zone 9, which includes areas on Mauna Kea and Mauna Loa that are above the 8,500-ft contour, evaporimeter data from Minyard and others (1994) for a station at 3,000 m (9,842 ft.) on Haleakalā, Maui, were used.

For climate-change scenarios, future mean pan evaporation was estimated by deriving a relation between historical pan evaporation and rainfall and applying the relation to projected future mean rainfall. Details of this methodology are given in the "Climate Change" subsection of the

Table 6. Ratios of monthly to annual pan evaporation for each pan-evaporation zone used in the water-budget calculation for the Island of Hawai'i.

[See figure 10 for locations of pan-evaporation zones; sta, station]

\begin{tabular}{|c|c|c|c|c|c|c|c|c|c|c|c|c|c|}
\hline \multirow{2}{*}{$\begin{array}{c}\text { Pan- } \\
\text { evaporation } \\
\text { zone }\end{array}$} & \multicolumn{12}{|c|}{ Ratio of monthly to annual pan evaporation } & \multirow{2}{*}{ Source station or reference } \\
\hline & Jan & Feb & Mar & Apr & May & June & July & Aug & Sept & Oct & Nov & Dec & \\
\hline 1 & 0.08 & 0.08 & 0.08 & 0.09 & 0.09 & 0.08 & 0.09 & 0.08 & 0.08 & 0.09 & 0.08 & 0.08 & $\begin{array}{l}\text { Kainaliu SCAN } \\
\quad \text { (solar radiation variability) }\end{array}$ \\
\hline 2 & 0.07 & 0.07 & 0.06 & 0.07 & 0.08 & 0.09 & 0.12 & 0.11 & 0.10 & 0.09 & 0.08 & 0.07 & $\begin{array}{l}\text { Waikoloa } 95.8 \\
\quad \text { (interpolated values in italics) }\end{array}$ \\
\hline 5 & 0.06 & 0.06 & 0.08 & 0.08 & 0.10 & 0.11 & 0.10 & 0.10 & 0.10 & 0.08 & 0.07 & 0.06 & Hāmākua Makai 221.3 \\
\hline 6 & 0.07 & 0.08 & 0.09 & 0.09 & 0.10 & 0.10 & 0.09 & 0.09 & 0.09 & 0.08 & 0.06 & 0.05 & $\begin{array}{l}\text { Juvik and Nullet (1994) } \\
\text { sta. 1,130 m (3,707 ft.) }\end{array}$ \\
\hline 7 & 0.08 & 0.07 & 0.08 & 0.09 & 0.09 & 0.10 & 0.10 & 0.09 & 0.09 & 0.08 & 0.06 & 0.07 & Hilo Airport 87 \\
\hline
\end{tabular}




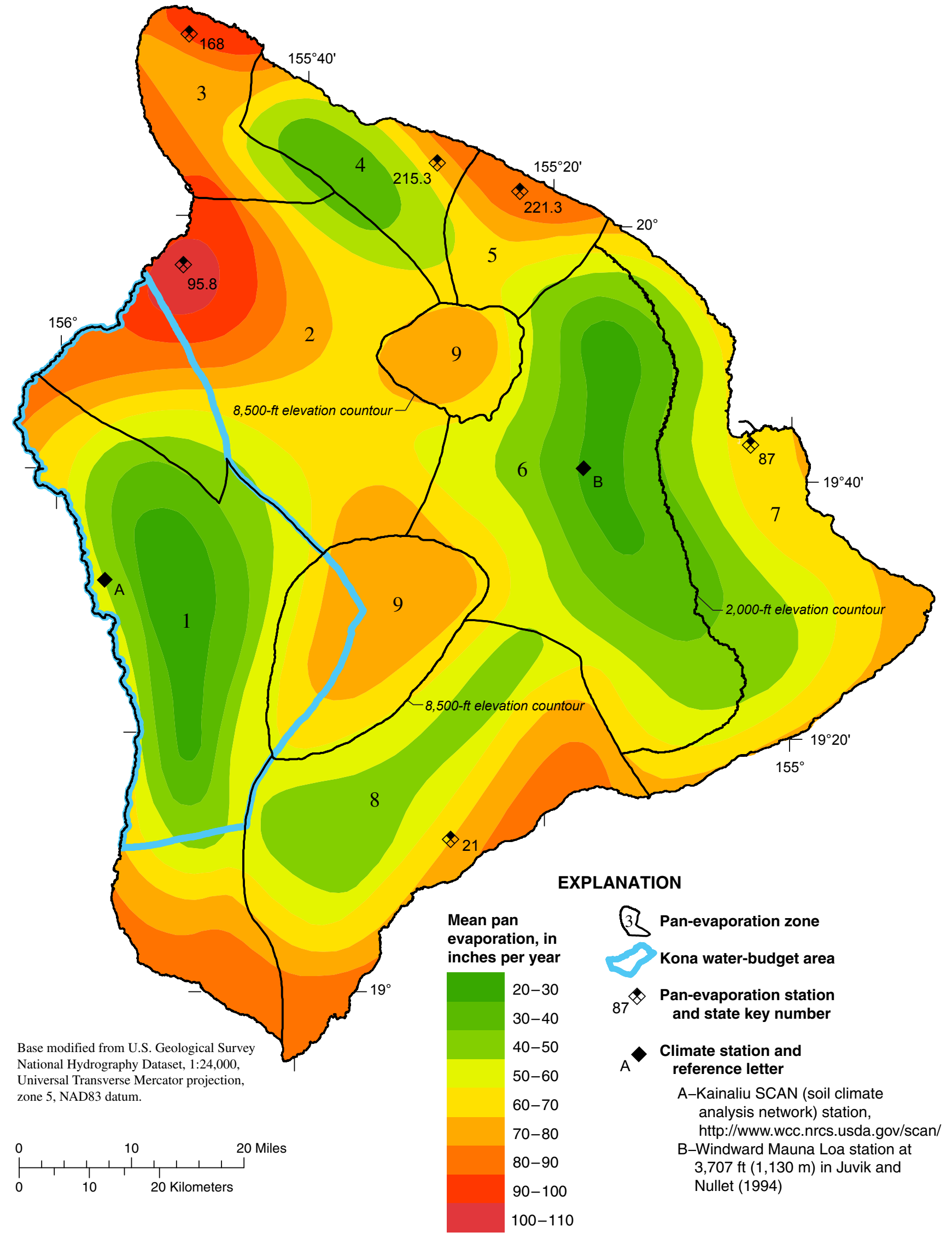

Figure 10. Mean annual pan evaporation (modified from Ekern and Chang, 1985) and pan-evaporation zones defined for the water-budget calculation on the Island of Hawai'i. 
"Groundwater-Recharge Estimates" section of this report. For model scenarios in which mean rainfall (with interannual variability), historical rainfall, or estimated drought conditions were used, mean pan evaporation was not altered from that derived from the Ekern and Chang (1985) map, even though rainfall was not necessarily equal to mean rainfall in these scenarios. This approach is consistent with recent water-budget studies for the Hawaiian Islands (for example, Oki, 2002; Izuka and others, 2005; Engott and Vana, 2007); moreover, the relations between historical pan evaporation and rainfall were deemed to be too weak to justify altering the long-term mean pan-evaporation distributions of Ekern and Chang (1985) for these scenarios. For climate-change scenarios, it was decided that a mean pan-evaporation distribution different from the historical one described by Ekern and Chang (1985) must be projected. The pan evaporation-to-rainfall relations, although weak, were used for climate-change scenarios owing to the dearth of available projections of future pan evaporation and other associated climate variables, such as solar radiation, wind speed, temperature, and relative humidity.

\section{Pan Coefficients}

Pan coefficients are ratios of potential ET to pan evaporation for a given land cover. For each nonforest land-cover category, a pan coefficient was assigned on the basis of data from a variety of sources (table 4). In this study, a significant number of pan coefficients were derived from the "crop coefficients" of Allen and others (1998). In their model, potential ET is termed "reference-crop evapotranspiration" and is defined as the evapotranspiration from a hypothetical grass surface of specific characteristics, with no soil-moisture stress. Allen and others (1998) estimate reference-crop evapotranspiration using a modified version of the PenmanMonteith equation (Monteith, 1965). As suggested in Allen and others (1998), a ratio of reference-crop evapotranspiration to pan evaporation, $k_{p}$, was used to convert their crop coefficients to the pan coefficients used in this study. The ratio $k_{p}$ was estimated using two methods. One method involved comparing sugarcane crop coefficients in Allen and others (1998) with data from the numerous sugarcane studies performed in Hawai'i. In Allen and others (1998), the crop coefficient assigned to the mid-growth stage of sugarcane is 1.25 , whereas the generally accepted pan coefficient in Hawaiian studies is 1.0 (Ekern, 1971; Fukunaga, 1978, Giambelluca, 1983). Using these two values, $k_{p}$ can be back calculated as $0.8(1.0 / 1.25)$. A second method for estimating $k_{p}$ was based on concurrent pan-evaporation and PenmanMonteith measurements made by Bean and others (1994) on Mauna Loa. In their study, mean Penman-Monteith evaporation was found to be 90 percent of mean pan evaporation, implying a $k_{p}$ of 0.9 . The average $k_{p}$ from these two methods, 0.85 , was used as $k_{p}$ in this study. Accordingly, all crop coefficients taken from Allen and others (1998) were converted to pan coefficients by multiplying by 0.85 . This conversion was also applied to crop coefficients taken from the irrigation model of Fares (2008), which is based on the same underlying theories as Allen and others (1998).

It is necessary for the water-budget model to estimate a pan coefficient for combined transpiration and ground evaporation in each forest land-cover category. In this study, forest land cover is separated into four categories: open native forest, closed native forest, mixed forest, and alien forest. In general, previous water budgets for the Island of Hawai ' $i$ (table 1) and other Hawaiian islands (see for example, Izuka and others, 2005; Engott and Vana, 2007) placed all forested areas into a single land-cover category, failing to account for nonuniformity in forest structure and species. Owing to the recent publication of improved land-cover maps (U.S. Geological Survey, 2006) and ongoing studies of Hawaiian forest hydrology (Santiago and others, 2000; Giambelluca and others, 2009a; Giambelluca and others. 2009b; Kagawa and others, 2009), it has become feasible to attempt to distinguish differences in water-budget parameters among different, albeit broad, categories of forest structure and species. Evidence exists that forests frequently affected by low clouds and fog transpire less water than forests in drier areas because of lower canopy conductances (Bruijnzeel and Veneklaas, 1998). Accordingly, each of the forest categories is divided into fog and nonfog subcategories on the basis of whether it is inside or outside the fog zone.

Whereas most ET studies in Hawai' $i$ have focused on agricultural crops, neglecting the forested watershed, one recent study, undertaken by Giambelluca and others (2009b) on Killauea, examined the evaporation and energy balance of a closed Metrosideros polymorpha (ohia) native forest, the most common forest type on the Island of Hawai' $i$. The site is located in the fog zone at an elevation of about 4,000 ft. They used eddy covariance measurements and a Bowen-ratio closure approach to estimate an annual total ET rate of 1,232 $\mathrm{mm}$ (48.5 in.), which was about 51 percent of annual rainfall (94.5 in.). To determine the pan coefficient for combined transpiration and ground evaporation necessary to reproduce the same ratio of total ET to rainfall, the recharge model was run multiple times with the pan coefficient incrementally changed for each successive run. The values of all other input parameters were set to baseline conditions, which used 2008 land cover and mean annual rainfall from the period 1916-1983, and were not altered for successive model runs. The pan coefficient that reproduced the 51 percent total-ET-to-rainfall ratio was 0.44 (table 4 ). Thus, all native fog forests were assigned this value.

Santiago and others (2000) measured sapflow to estimate transpiration in a closed $M$. polymorpha forest on East Maui. They reported transpiration rates at three nonwaterlogged sites that were 79 to 89 percent of Penman-Monteith evaporation during the 5 days with the highest evaporative demand. Adding the estimated rate of daily ground evaporation of 0.10 mm (0.004 in.) reported by Jordan and Heuveldop (1981) for tropical rainforest in Venezuela, results in values ranging from 81 to 95 percent of Penman-Monteith evaporation. Converting to pan evaporation using a $k_{p}$ of 0.85 yields pan coefficients 
for combined transpiration and ground evaporation ranging from 0.69 to 0.81 , with an average value of 0.74 for the three sites. Although it was not explicitly stated in Santiago and others (2000), it could be assumed that during these 5-day periods the presence of fog was minimal. In a different study, Giambelluca and others (2009a) measured sapflow to estimate transpiration in a native $M$. polymorpha forest on the Island of Hawai'i during periods of wet and dry canopy. The mean transpiration rate during periods when the canopy was partially wet was reported to be 47 percent of transpiration during dry-canopy periods. If it is assumed that the result is representative of transpiration in native fog forests (partially wet canopy) and transpiration in native nonfog forests (dry canopy), then the pan coefficient for native nonfog forest could be computed from the pan coefficient for native fog forest $(0.44)$ by dividing it by 0.47 . The resulting value is 0.94 . In the water-budget model, 0.84 was used as the combined transpiration and ground-evaporation pan coefficient for native nonfog forest. This is the average of the values derived from the Santiago and others (2000) study and the Giambelluca and others (2009a) study.

In general, invasive alien species of trees consume more water through ET than native species (Calder and Dye, 2001). On leeward Mauna Loa, Kagawa and others (2009) reported transpiration rates, as measured by sapflow, in an alien Eucalyptus saligna plantation and an alien Fraxinus uhdei (tropical ash) forest that were, respectively, about 1.3 and 2.5 times the rate in a native $M$. polymorpha forest. The pan coefficient used in this study for alien forest inside the fog zone is 0.88 , twice the pan coefficient for native forest inside the fog zone $(0.44 \times 2)$. This is also the pan coefficient used for mixed alien/native forest inside the fog zone. Outside the fog zone, the pan coefficient for both of these two forests types is $1.68(0.84 \times 2)$. The pan coefficient for agricultural forest (eucalyptus) is also 1.68. Agricultural forest (eucalyptus) only occurs outside the fog zone.

Differences in ET between open and closed canopy forests largely are a matter of degree of canopy openness or gap fraction (Tobon Marin and others, 2000). ET rates in forests are highly localized. In more open forest settings, individual trees may have high rates of ET owing to higher aerodynamic roughness and increased insolation, whereas closed forests generally have more trees that may intercept and transpire more water in total. Owing to this indeterminacy and lack of applicable studies, no distinction is made in the water-budget model between open and closed forests with regard to pan coefficients.

For other land-cover categories in this study, the pan coefficients assigned are based on total ET. Both shrubland and diversified agriculture were assigned a pan coefficient of 0.85, the same as in Izuka and others (2005) and Engott and Vana (2007). Pan coefficients for wetland vegetation, fallow/grassland, golf course, and grassland were derived from Allen and others (1998). The golf-course pan coefficient is based on the warm-season turfgrass listing. The pan coefficient for macadamia was derived from Fares (2008), and the pan coefficient for coffee is the average of the coefficients derived from Allen and others (1998) and Fares (2008). Pan coefficients for low-intensity and high-intensity developed land are based on the urban category in Giambelluca (1983). The sparsely vegetated land-cover category mainly consists of recent, unvegetated, lava flows (U.S. Geological Survey, 2006). Owing to a dearth of studies on the evaporation properties of bare lava, this category was treated like a bare soil, the same approach used by Contor (2004) for a study of recharge beneath lava flows in Idaho. Results from Contor (2004) were subsequently used in a recharge assessment for parts of Idaho and Washington (Bartolino, 2007). Penman (1948) reported the rate of bare-soil evaporation to be 90 percent of pan evaporation. Ekern (1966) reported that a bare latosol soil on $\mathrm{O}^{\prime}$ ahu exhibited an evaporation rate that was 36 percent of a fully vegetated surface. However, this soil displays a self-mulching action (Ekern, 1966) that is unlikely to occur in bare lava. Allen and others (1998) suggests a pan-coefficient range of 0.9 to 1.1 (converted using $k_{p}$ ) for bare soil. On the basis of Allen and others (1998) and the assumption that bare lava and bare soil share similar evaporation properties, a pan coefficient of 1.0 was assigned to sparsely vegetated land in this study.

\section{Moisture-Storage Capacity}

Moisture-storage capacity was computed as the product of available water capacity and root depth (equation 8). Figure 11 displays the distribution of moisture-storage capacities on the Island of Hawai' $i$.

Available water capacity varies by soil type and is a measure of the maximum depth of water per unit depth of soil available for consumption by plants. Previously published soil maps and corresponding tables of available water capacities (U.S. Department of Agriculture, 2008) were used to distribute available water capacity over the study area. The published tables list available water capacities for each soil type as minimum and maximum values at various ranges of depth. In this study, a depth-weighted average available water capacity was then computed and assigned to each soil type.

Root depth varies by land-cover category (table 4). In this study, assignments of root depths were based on previously published information. The root depth for open native forest is the same as in Giambelluca (1983) for dry forest and in Shade (1995) for open koa forest. The root depth for closed native forest is the same as in Shade (1995) for closed ohia/ fern forest and in Oki (2002) for forest with canopy coverage greater than 25 percent. The root depth for alien forest is the average root depth given for young and old eucalyptus in Fares (2008). The root depth for mixed forest is the average of the root depths for closed native forest and alien forest. The root depth for shrubland is the same as in Giambelluca (1983) for dry scrub. The root depths for macadamia, coffee, and diversified agriculture are based on Fares (2008). Root 


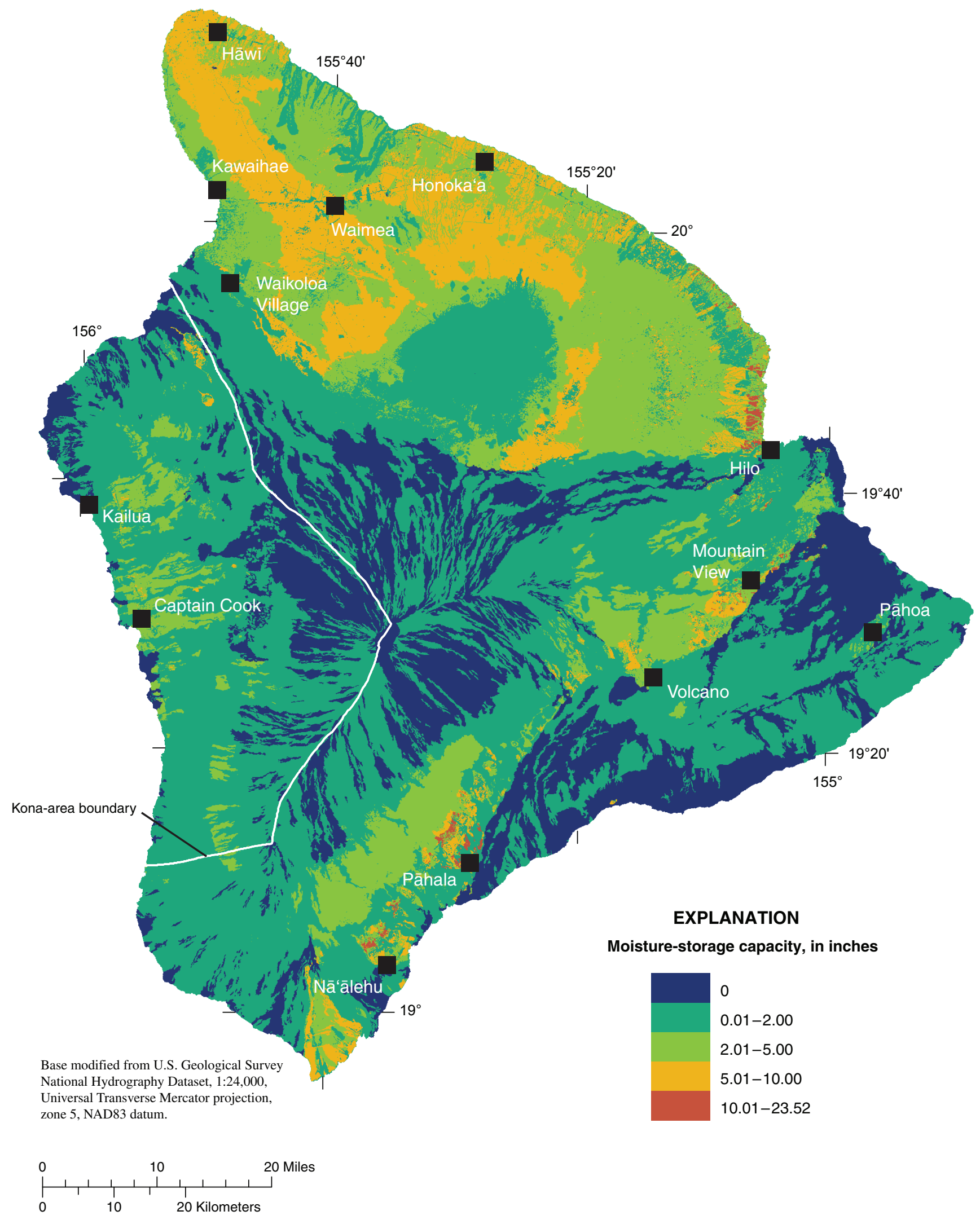

Figure 11. Calculated moisture-storage capacity on the Island of Hawai i. 
depths for fallow/grassland, golf course, and grassland are based on Allen and others (1998). The golf-course root depth is based on the warm-season turfgrass listing. Root depths for low-intensity and high-intensity developed land are based on the urban category in Giambelluca (1983). The root depth for sparsely vegetated land is the average of the high and low values suggested by Allen and others (1998) for bare soil. The root depth for wetland vegetation is the same as in Engott and Vana (2007).

\section{Direct Recharge}

In this study, "direct recharge," $D R$, is defined as water that passes directly to the groundwater system, completely bypassing the plant-soil zone (see equation 11). Direct recharge is not subject to runoff or ET. Three important anthropogenic sources of direct recharge on the Island of Hawai' $i$ are (1) cesspool leakage, (2) water-main leakage, and (3) the disposal pit for treated effluent from the Kealakehe Wastewater Treatment Plant.

Cesspool leakage was calculated on the basis of censusblock population maps (State of Hawai' $i$, 2001) of areas served by wastewater treatment plants (County of Hawai 'i, 2009) and an estimated rate of daily domestic water use of 100 gallons per capita per day (County of Hawai' $i, 2006$ ). Areas of the island not serviced by wastewater treatment plants were assumed to be areas exclusively using cesspools. The rate of leakage in the cesspool areas was computed as the population of that area multiplied by the rate of daily domestic water use. The resulting rate was applied uniformly over the entire area.

Water-main leakage was calculated on the basis of maps of county and private water mains in the County of Hawai' $i$ (2006) Water Use and Development Plan Update and information on the amount of water that goes unmetered and is assumed lost in the public water system, according to the HDWS (Larry Beck, HDWS, written commun., 2009). For this study, the total amount of water-main leakage on the island was estimated to be 1.2 Mgal/d and was applied at a uniform rate along the length of each water main.

The Kealakehe Wastewater Treatment Plant serves part of the Kona area in and around the town of Kailua (fig. 1). Effluent from the plant is disposed in a pit located just east of Honokōhau Bay. The estimated rate of effluent disposal used in this study was $1.5 \mathrm{Mgal} / \mathrm{d}$, based on information in a County of Hawai ‘i (2008) Planning Department report.

Another source of direct recharge is seepage from the 2,052 dry wells on the island that are used to dispose of runoff from paved surfaces. The drainage area of each dry well and the volumetric rate of water disposed are largely unknown. Hence, estimation of direct recharge from dry wells is not attempted in this report; however, it could be important to the local quality and quantity of recharge (Izuka and others, 2009).

\section{Other Input}

In addition to the water-budget inputs already discussed, several other inputs are required. The initial moisture storage was set at 50 percent of capacity; the rainfall-interception capacity for impervious surfaces was set at $0.25 \mathrm{in}$.; and the rate of groundwater recharge from surface-water bodies was set at $12 \mathrm{in} / \mathrm{yr}$. The values assigned to these parameters are consistent with those for other recent Hawai' $i$ water budgets (Izuka and others, 2005; Engott and Vana, 2007). The effects of these parameters on regional-scale recharge generally are minor because they either pertain to only a small area or are applicable during only a small fraction of time.

\section{Model Randomness}

The selection of monthly rainfall fragment sets (see "Rainfall" section) introduces randomness into the water-budget model. To account for this randomness, the water-budget model was run multiple times, and the results were averaged. To determine the appropriate number of simulations to run, the water-budget model for the Island of Hawai ' $i$ was run 50 times. The marginal, absolute percentage change in groundwater recharge for each of the 467,805 subareas was averaged for each number of simulations and is shown on figure 12 . After 20 simulations, the average percentage change did not exceed 0.1 percent. This very small value, 0.1 percent, was determined to be adequate for this study. Accordingly, for each model scenario, the water-budget model was run 20 times, and the results were averaged.

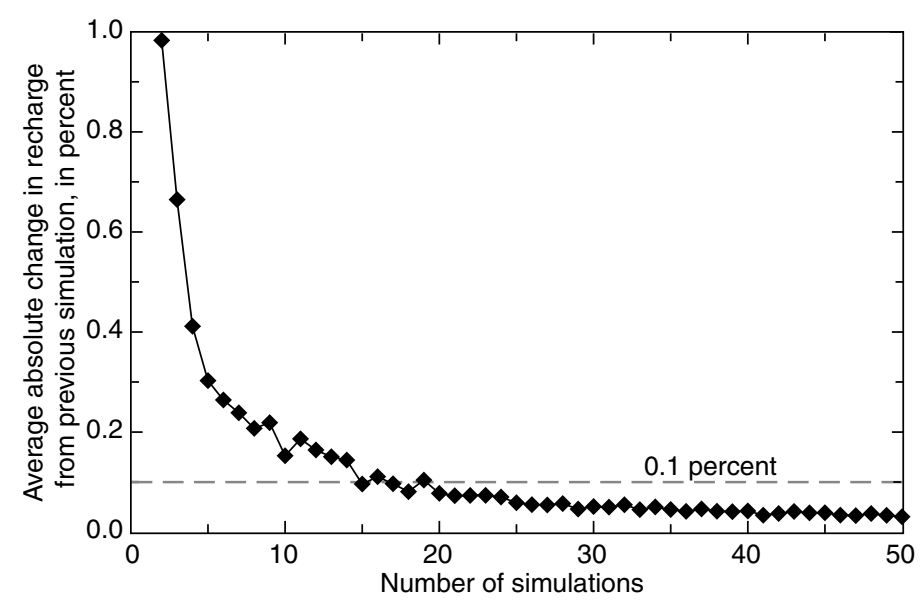

Figure 12. The average absolute percentage change in recharge of all the water-budget subareas with each successive model simulation. 


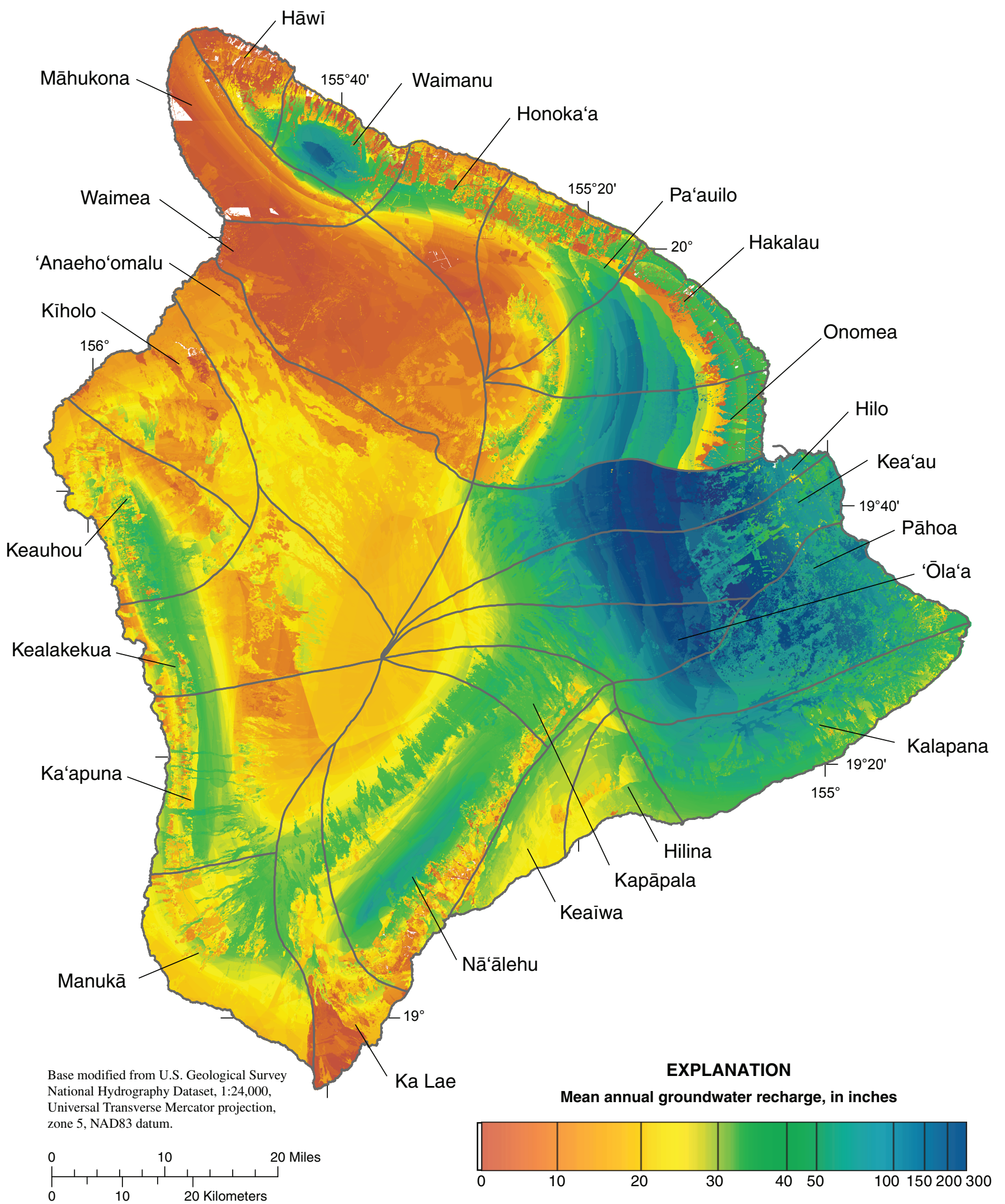

Figure 13. The distribution of mean annual groundwater recharge for baseline conditions on the Island of Hawai' $i$ calculated using the water-budget model. Areas of zero recharge appear as white. Boundaries of named aquifer systems (State of Hawai'i, 2008) are shown in gray. 
Table 7. Mean annual water-budget estimates for baseline and possible future conditions for each aquifer system on the Island of Hawai'i.

[Baseline condition is 2008 land cover with mean rainfall from Giambelluca and others (1986); drought condition is 2008 land cover with lowest observed 5-year average rainfall; urbanization I is land cover based on full development of parcels zoned for urban use by Hawai'i County (2007) with mean rainfall from Giambelluca and others (1986); urbanization II is land cover based on full development of urban parcels in the Land Use Pattern Allocation Guide (LUPAG) (County of Hawai ' $i$, 2005) with mean rainfall from Giambelluca and others (1986); the alien-forest-to-native scenario is baseline conditions with alien-forest and mixed-forest land covers changed to open-canopy native forest; climate change I is land cover based on full development of urban parcels in the LUPAG (County of Hawai ' $\mathrm{i}$, 2005) with estimated rainfall for late 21st century based on the upper margin of the 95-percent statistical confidence interval of the six-model ensemble from Timm and others (2009); climate change II is land cover based on full development of urban parcels in the LUPAG (County of Hawai' $\mathrm{i}$, 2005) with estimated rainfall for late 21st century based on the mean of the six-model ensemble from Timm and others (2009); climate change III is land cover based on full development of urban parcels in the LUPAG (County of Hawai' $\mathrm{i}$, 2005) with estimated rainfall for late 21st century based on the lower margin of the 95-percent statistical confidence interval of the six-model ensemble from Timm and others (2009); Mgal/d, million gallons per day; Irr, irrigation; DR, direct recharge; ET, evapotranspiration exclusive of canopy evaporation; CEvap, canopy evaporation in forested areas; Rech, recharge; WRPP, Water Resources Protection Plan (State of Hawai ‘i, 1990)]

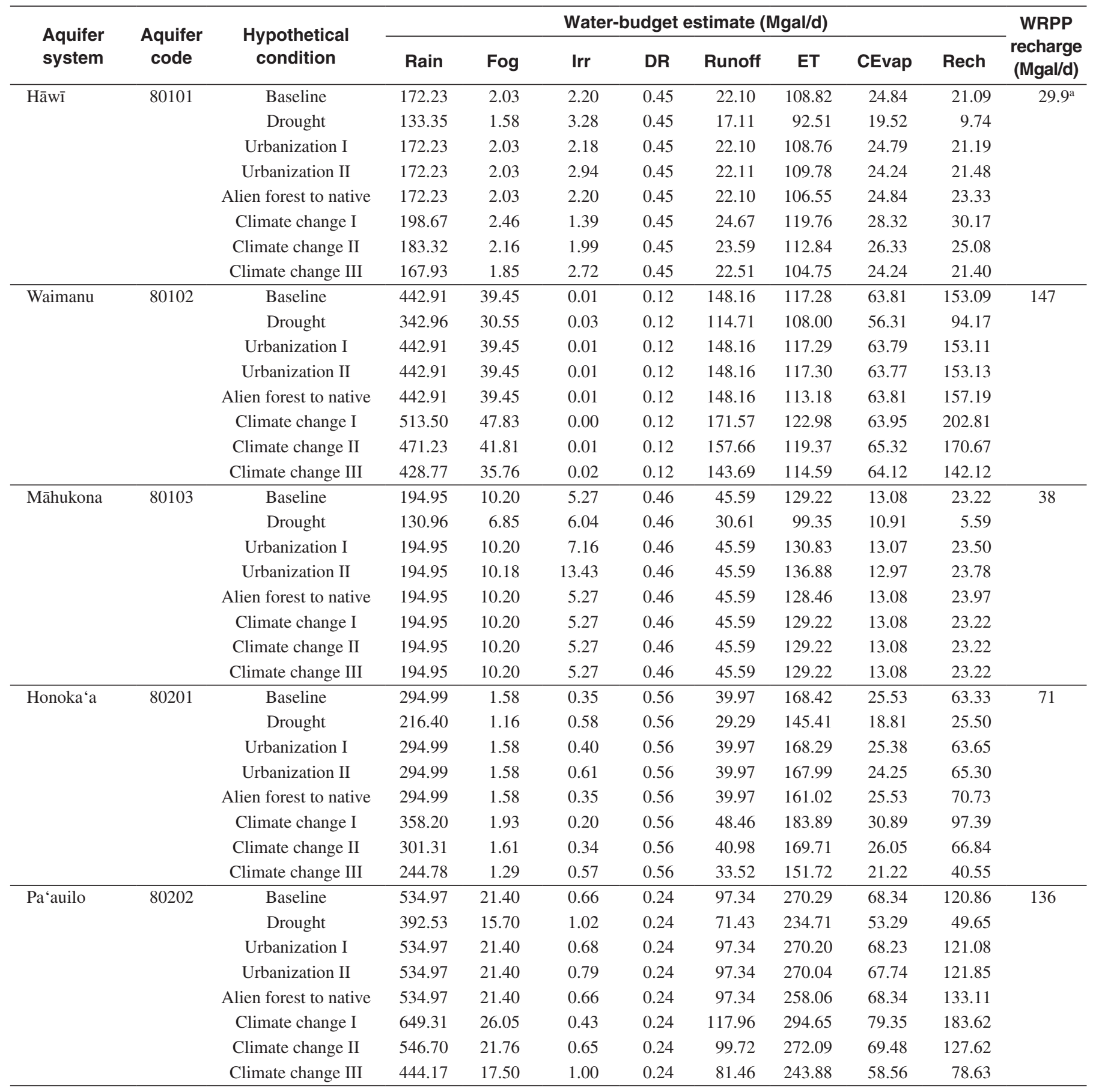


Table 7. Mean annual water-budget estimates for baseline and possible future conditions for each aquifer system on the Island of Hawai'i.-Continued

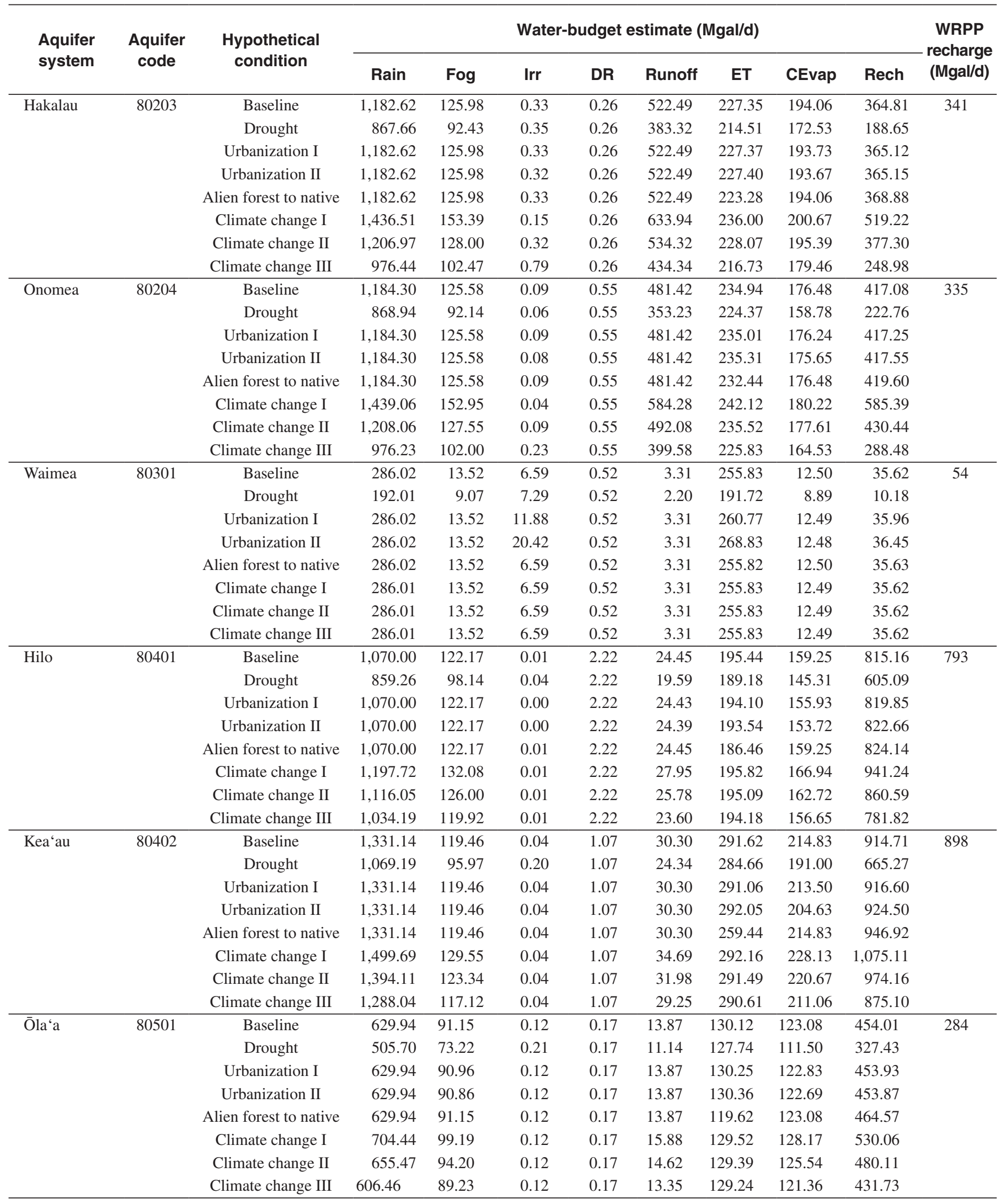


Table 7. Mean annual water-budget estimates for baseline and possible future conditions for each aquifer system on the Island of Hawai'i.-Continued

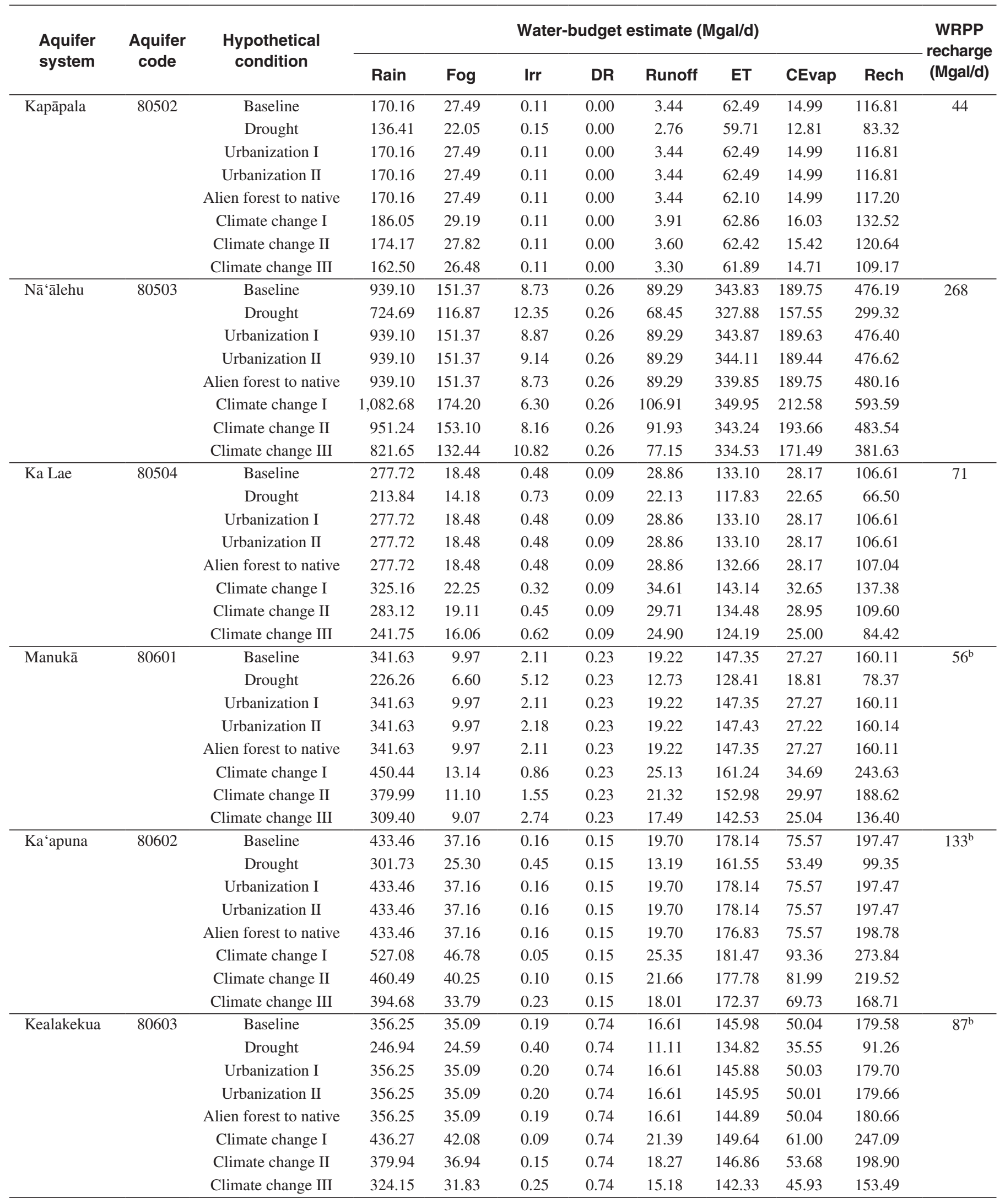


Table 7. Mean annual water-budget estimates for baseline and possible future conditions for each aquifer system on the Island of Hawai'i.-Continued

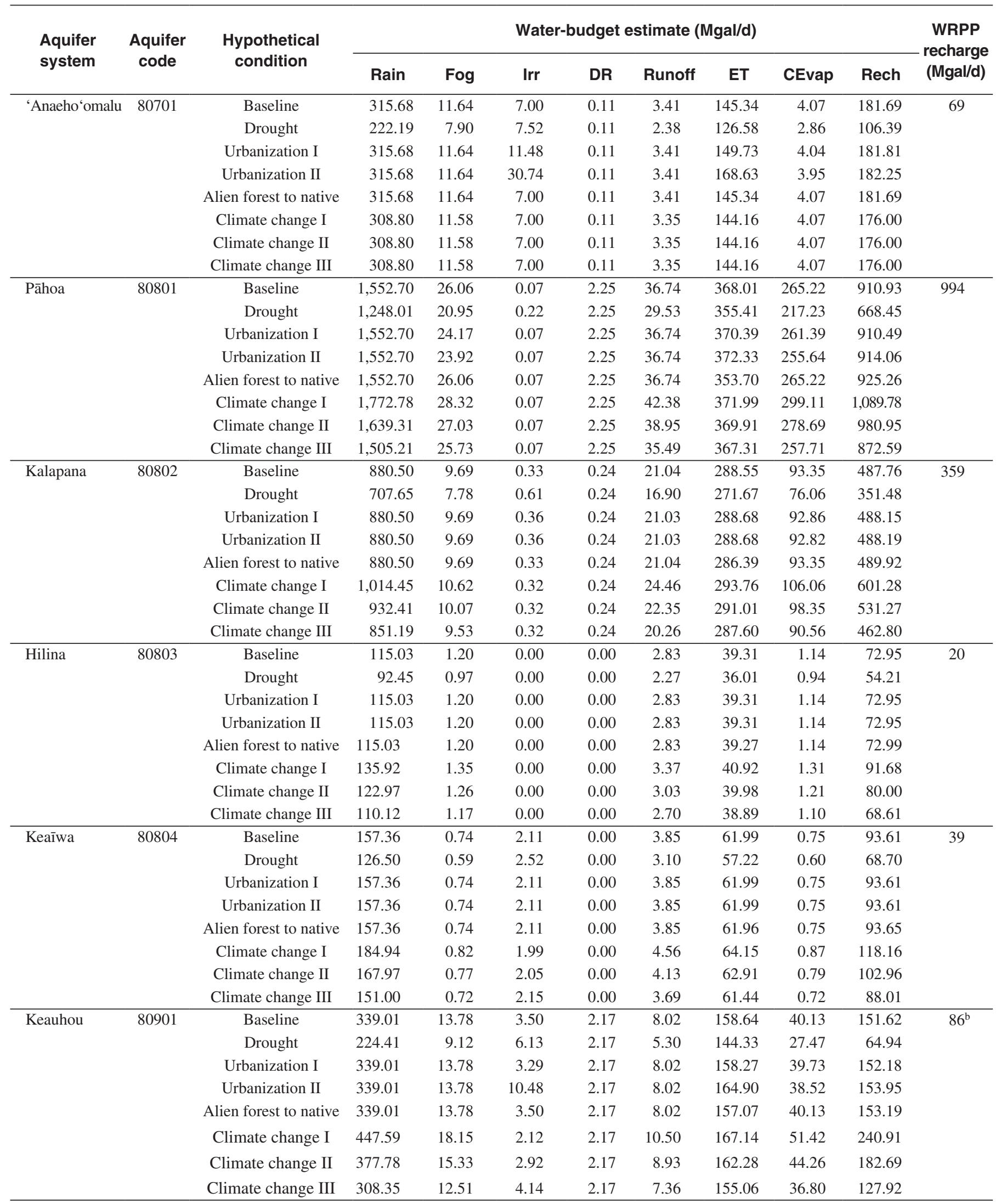


Table 7. Mean annual water-budget estimates for baseline and possible future conditions for each aquifer system on the Island of Hawai'i.-Continued

\begin{tabular}{|c|c|c|c|c|c|c|c|c|c|c|c|}
\hline \multirow{2}{*}{$\begin{array}{l}\text { Aquifer } \\
\text { system }\end{array}$} & \multirow{2}{*}{$\begin{array}{l}\text { Aquifer } \\
\text { code }\end{array}$} & \multirow{2}{*}{$\begin{array}{l}\text { Hypothetical } \\
\text { condition }\end{array}$} & \multicolumn{8}{|c|}{ Water-budget estimate (Mgal/d) } & \multirow{2}{*}{$\begin{array}{l}\text { WRPP } \\
\text { recharge } \\
\text { (Mgal/d) }\end{array}$} \\
\hline & & & Rain & Fog & Irr & DR & Runoff & ET & CEvap & Rech & \\
\hline \multirow[t]{8}{*}{ Kīholo } & 80902 & Baseline & 176.04 & 7.75 & 3.44 & 0.08 & 3.95 & 99.21 & 7.96 & 76.19 & 42 \\
\hline & & Drought & 116.53 & 5.13 & 4.06 & 0.08 & 2.63 & 83.19 & 5.51 & 34.77 & \\
\hline & & Urbanization I & 176.04 & 7.75 & 3.65 & 0.08 & 3.95 & 99.41 & 7.96 & 76.19 & \\
\hline & & Urbanization II & 176.04 & 7.75 & 7.11 & 0.08 & 3.95 & 102.84 & 7.93 & 76.27 & \\
\hline & & Alien forest to native & 176.04 & 7.75 & 3.44 & 0.08 & 3.95 & 99.21 & 7.96 & 76.19 & \\
\hline & & Climate change I & 231.79 & 10.18 & 2.93 & 0.08 & 5.16 & 110.19 & 10.09 & 119.55 & \\
\hline & & Climate change II & 195.55 & 8.60 & 3.25 & 0.08 & 4.39 & 103.84 & 8.74 & 90.52 & \\
\hline & & Climate change III & 158.96 & 7.02 & 3.61 & 0.08 & 3.61 & 95.22 & 7.29 & 63.58 & \\
\hline
\end{tabular}

aThis recharge value was used in the 2008 WRPP (State of Hawai' $i$, 2008) based on Oki (2002).

${ }^{b}$ This recharge value was used in the 2008 WRPP (State of Hawai' $i, 2008$ ) based on Oki (1999).

\section{Groundwater-Recharge Estimates}

\section{Baseline Recharge}

Estimated mean annual recharge on the Island of Hawai' $\mathrm{i}$ is $6,594 \mathrm{Mgal} / \mathrm{d}$ for baseline conditions. Baseline conditions for this study were 2008 land cover and mean annual rainfall (1916-1983) based on Giambelluca and others (1986). Recharge is about 49 percent of rainfall and about 46 percent of total water inflow (sum of rainfall, fog interception, and irrigation). The spatial distribution of estimated mean annual recharge for baseline conditions is displayed on figure 13 and tabulated by aquifer system on table 7 .

Estimated mean annual recharge on the Island of Hawai ' $i$ is highest on the windward slopes of Mauna Loa, below the tradewind inversion, and lowest on the leeward slopes of Kohala and Mauna Kea. Local recharge maxima also occur on (1) the higher elevations of windward Kohala, (2) windward Mauna Kea below the tradewind inversion, (3) windward Kîlauea, (4) the middle elevations of southeastern Mauna Loa, and (5) the lower middle elevations of leeward Mauna Loa and southwestern Hualālai, in the Kona area. Local recharge minima also occur on (1) Mauna Kea and Mauna Loa, above the tradewind inversion, (2) the northern tip of Kohala, (3) leeward Kilauea, (4) the southern tip of Mauna Loa, and (5) the northwestern slopes of Mauna Loa and Hualālai. The aquifer systems receiving the most estimated recharge are, in order, Kea 'au, Pāhoa, and Hilo. The aquifer systems receiving the least estimated recharge are, in order, Hāwī, Māhukona, and Waimea.

A pronounced discontinuity in recharge distribution occurs along the boundary of the Onomea and Hilo aquifer systems. This discontinuity is due to the difference in runoff properties between Mauna Kea, of which the Onomea aquifer system is part, and Mauna Loa, of which the Hilo aquifer system is part. Rainfall, pan-evaporation, fog-interception, and land-cover characteristics are comparable in the two aquifer systems; however, runoff in the Onomea aquifer system is markedly higher. The surface of Mauna Kea, being older than Mauna Loa, is more eroded and less permeable.

Another noticeable feature of figure 13 is the belt of lower recharge running parallel to the coast about 2 to 5 miles inland in the Hakalau and Onomea aquifer systems, This feature occurs where forest exists below the lower extent of the fog zone, which was set at 2,500 ft for this study. Within the belt, relatively high rates of ET occur because of canopy evaporation. West of the belt, in the fog forest, estimated recharge is higher because of fog interception and lower ET rates associated with lower transpiration in fog forests. East of the belt, in the grassland and agricultural land covers, estimated recharge is higher because of lower ET rates associated with the absence of canopy evaporation. Whereas the elevation of the lower extent of the fog zone $(2,500 \mathrm{ft})$ was somewhat arbitrarily set and is certainly debatable, the eastern boundary is indisputably the edge of the forest land, documented in the GAP land-cover map (U.S. Geological Survey, 2006). This shows that forested land does not necessarily provide more groundwater recharge than grassland and agricultural land.

Figure 14 shows the estimated fraction of total water inflow-rainfall, fog interception, and irrigation - that becomes groundwater recharge. The areas with the highest fraction, greater than 80 percent, mainly occur in the wettest areas of the highly permeable slopes of Mauna Loa and Kilauea. In these areas, runoff is very low and the moisturestorage capacity is relatively low (fig. 11). Areas with a low fraction, less than 20 percent, include the northern and southern tips of the island, leeward Kohala and Mauna Kea, the saddle between Kohala and Mauna Kea, coastal areas of northeastern Mauna Kea and Kohala, and the forested areas of 


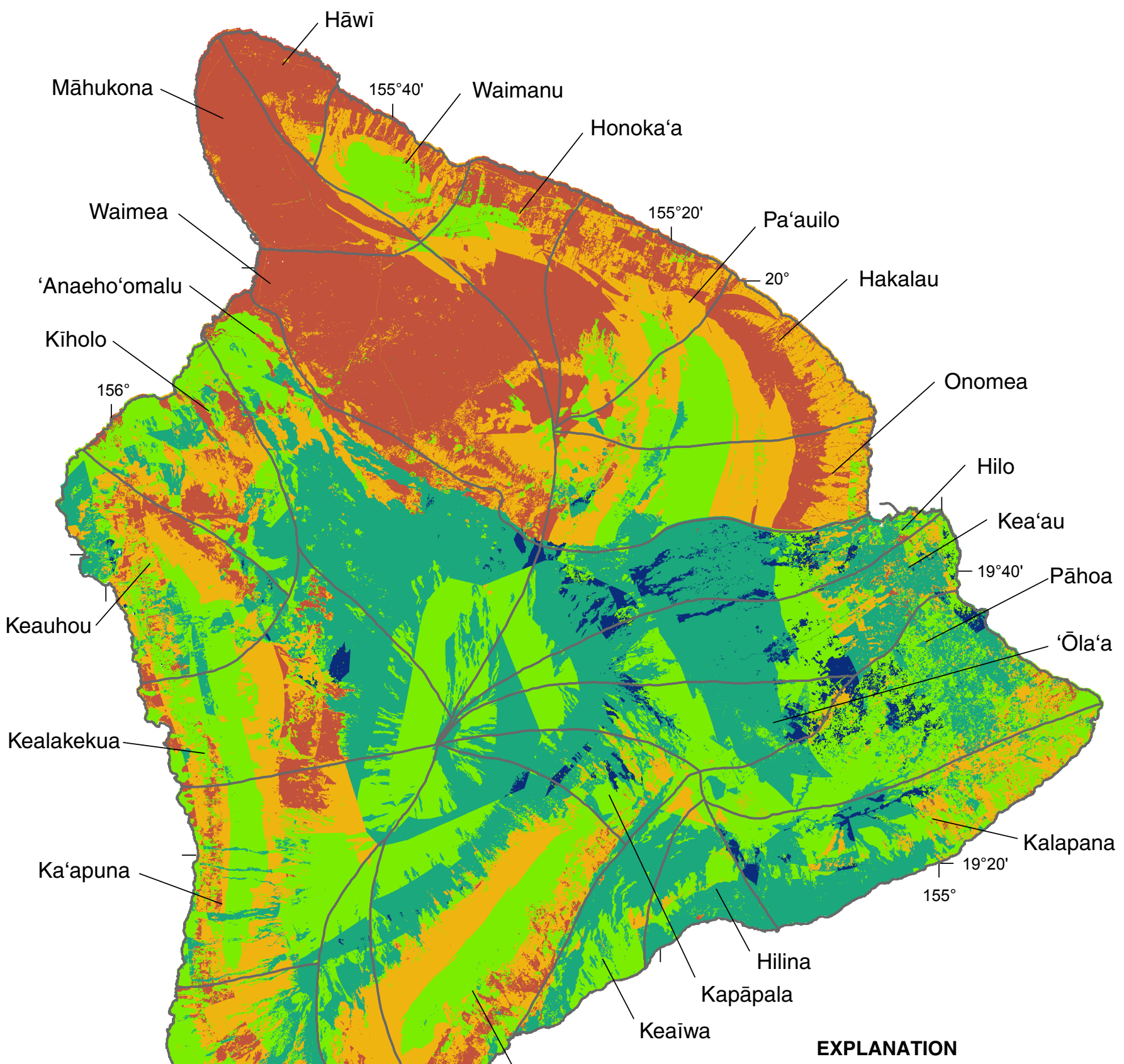

Fraction of water inflow (rain, fog, interception, and irrigation) that

Manukā

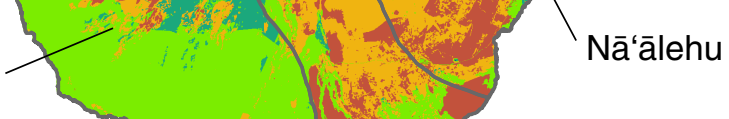
becomes recharge, in percent

Less than 20
$20-39$
$40-59$
$60-79$
80 and greater

National Hydrography Dataset, 1:24,000,

Universal Transverse Mercator projection, zone 5, NAD83 datum.

20 Miles

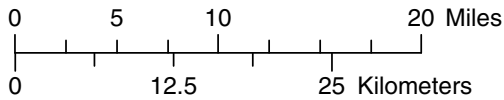

Figure 14. Estimated fraction of total water inflow that becomes groundwater recharge in the water-budget simulation for mean annual recharge for baseline conditions on the Island of Hawai'i. Boundaries of named aquifer systems (State of Hawai $i, 2008$ ) are shown in gray. 
eastern Mauna Kea below the fog zone (2,500 ft.). These areas generally correspond to areas of high pan evaporation and/or high moisture-storage capacity. In the forested areas of eastern Mauna Kea below the fog zone, the low fractions are caused by high rates of canopy-interception loss.

\section{Comparison to Water Resources Protection Plan}

In 1990, CWRM published the Water Resources Protection Plan (WRPP). The WRPP (State of Hawai 'i, 1990) assigned estimates of sustainable yield to each aquifer system in the State. Sustainable yield refers to the forced groundwater-withdrawal rate that could be sustained indefinitely without affecting either the quality of the pumped water or the volume rate of pumping (State of Hawai 'i, 1990). The estimation of sustainable yield in the 1990 WRPP was based on a simple formula that required estimates of recharge, among other parameters. In 2008, CWRM published an updated WRPP (State of Hawai 'i, 2008), which used a revised methodology for calculating sustainable yield that also required recharge estimates. Most recharge estimates from the 1990 WRPP were carried over to the 2008 WRPP; however, some were revised on the basis of recent studies by the USGS (Oki, 1999; Oki, 2002). Values for recharge estimates are not explicitly given in the 2008 WRPP. Table 7 compares the estimates of baseline groundwater recharge from this study to the estimates published in the 1990 WRPP. Where noted, recharge values that were used in the 2008 WRPP (Lenore Ohye, CWRM, written commun., 2009) are used for comparison instead of the 1990 values.

For most of the island, recharge estimates computed using the methods of this study are substantially higher than those estimated in the 1990 WRPP and carried over to the 2008 WRPP (table 7; figure 15). The reasons for differences in the recharge estimates are related to the methods used to estimate the individual water-budget components. A brief, generalized description of the methods used in the estimation of waterbudget components is given in the 1990 WRPP. From this description it is difficult to ascertain the exact approach used for each aquifer system. Therefore, discussion of the differences between the 1990 WRPP methods and the methods used in this study is limited to generalities. The key general differences are as follows: (1) The 1990 WRPP water budget was calculated by using an annual time step, whereas this study uses a daily time step. In general, a finer time step will generate a more realistic recharge estimate than a coarser time step (Oki, 2008). (2) The 1990 WRPP water budget omitted estimates of fog interception, whereas this study includes them. All other factors being equal, the inclusion of fog interception results in a higher estimate of total water inflow. (3) The 1990 WRPP water budget estimated runoff from streamflow measurements without subtracting base flow, whereas this study subtracts base flow, generating a lower runoff estimate. (4) The 1990 WRPP water budget estimated annual ET as potential (maximum) ET, whereas this study calculates daily ET on the basis of available soil moisture, vegetative cover, and soil type. In general, this approach will generate a lower ET estimate than the 1990 WRPP. In summary, the methods used in this study tend to result in a higher estimate of water input than the 1990 WRPP, a lower estimate of runoff, and a lower estimate of ET. The net effect is the generally higher recharge estimates in this study.

Māhukona, Waimea, and Hāwī aquifer systems are three notable exceptions in which groundwater recharge estimated in this study is lower than the WRPP recharge estimate (table 7; figure 15)_estimated recharge is 38, 34, and 29 percent lower, respectively. For the Māhukona aquifer system, both runoff and ET are much higher in this study than in the 1990 WRPP water budget (table 8 ). The runoff and ET estimates are so much higher, in fact, that they completely offset the much higher rainfall estimate in this study and also the inclusion of fog interception and irrigation. An unpublished consultant report by Pacific Hydrogeologic, LLC (2006) titled "Water budget and numerical analysis of Mahukona aquifer system, North and South Kohala, Hawai 'i," which calculated recharge using methods similar to this study, gives an even lower estimated mean annual recharge for the Māhukona aquifer system (table 8). Estimates from this study for rainfall and runoff compare very well to that Pacific Hydrogeologic consultant report, providing some confidence that this study may have better estimates for these components than the 1990 WRPP. For the Waimea aquifer system, the ET estimate in this study is about 54 percent higher than that used in the 1990 WRPP water budget (table 8), The much higher ET estimate is primarily responsible for the estimate of recharge in this study being lower than the 1990 WRPP, even despite a higher total water inflow. For the Hāwī aquifer system, recharge estimated in this study is about 29 percent lower than the 2008 WRPP estimate, which was based on a water budget calculated by Oki (2002) using methods similar to the water-budget model in this report. A likely source of this discrepancy is that Oki (2002) did not directly account for canopy-interception loss in forested areas, whereas this study does.

\section{Drought Conditions}

Analysis of the effect of drought conditions on the Island of Hawai 'i made use of the rainfall-variability zones described in the "Rainfall" section of this report (fig. 6). For each rainfall-variability zone, the time period with the lowest 5-year average rainfall was selected as the drought period (table 2). The water-budget model was run using the same input as the baseline simulation, except that rainfall from the historical drought periods was used instead of mean rainfall.

The spatial distribution of groundwater recharge for drought conditions is shown on figure 16. The relative distribution of recharge is similar to the baseline simulation; however, the overall rates of recharge are lower because of the lower rainfall associated with the drought condition. A large area of zero recharge occurs at the middle elevations of leeward Mauna Kea and in the saddle between Mauna Kea and Kohala, mostly within the Waimea aquifer system. 


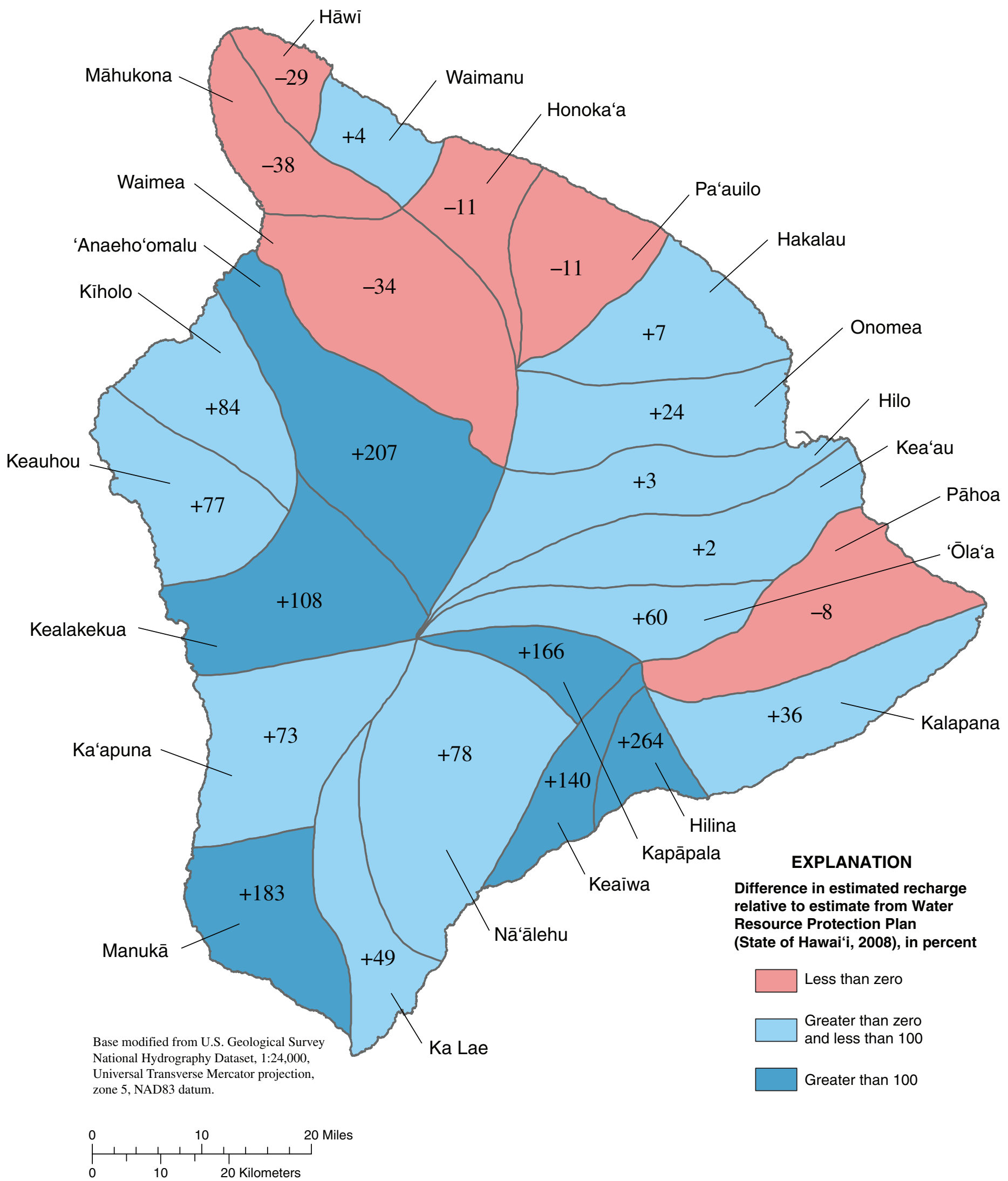

Figure 15. Relative difference, by aquifer system, between the recharge calculated in this study and the recharge used in the Water Resource Protection Plan (State of Hawai'i, 2008). 
Table 8. Comparison of the baseline water budget calculated in this study with other studies for selected aquifer systems on the Island of Hawai'i.

[Mgal/d, million gallons per day; 1990 WRPP, 1990 Water Resource Protection Plan (State of Hawai 'i, 1990); Irr, irrigation; RO, runoff; ET, evapotranspiration; Rech, recharge; -, value not given in referenced report]

\begin{tabular}{|c|c|c|c|c|c|c|c|}
\hline \multirow{2}{*}{$\begin{array}{l}\text { Aquifer } \\
\text { system }\end{array}$} & \multirow{2}{*}{ Study } & \multicolumn{6}{|c|}{ Water-budget estimate (Mgal/d) } \\
\hline & & Rain & Fog & Irr & RO & ET & Rech \\
\hline \multirow[t]{3}{*}{ Māhukona } & 1990 WRPP & 135.52 & 0.00 & 0.00 & 5.42 & 92.15 & 38.00 \\
\hline & Pacific Hydrogeologic, LLC (2006, unpub.) & 195.60 & - & - & 43.81 & - & 22.60 \\
\hline & Baseline, this study & 194.95 & 10.20 & 5.27 & 45.59 & $142.3^{\mathrm{a}}$ & 23.22 \\
\hline \multirow[t]{2}{*}{ Waimea } & 1990 WRPP & 241.68 & 0.00 & 0.00 & 13.43 & 174.55 & 54.00 \\
\hline & Baseline, this study & 286.02 & 13.52 & 6.59 & 3.31 & $268.33^{\mathrm{a}}$ & 35.62 \\
\hline \multirow[t]{2}{*}{ Hāwī } & Oki (2002) & - & - & - & - & - & 29.90 \\
\hline & Baseline, this study & 172.23 & 2.03 & 2.20 & 22.10 & $133.66^{\mathrm{a}}$ & 21.09 \\
\hline
\end{tabular}

${ }^{\mathrm{a} I n c l u d e s}$ canopy evaporation from forests (see table 7).

Overall recharge in the Waimea aquifer system is substantially reduced, from $35.62 \mathrm{Mgal} / \mathrm{d}$ for baseline conditions to 10.18 $\mathrm{Mgal} / \mathrm{d}$ for drought conditions (table 7). This recharge estimate is considerably less than the sustainable yield of $24 \mathrm{Mgal} / \mathrm{d}$ set in the 2008 WRPP (State of Hawai 'i, 2008). Large areas of zero recharge also occur on the leeward slopes of Kohala within the Māhukona aquifer system. Overall recharge in the Māhukona aquifer system also is substantially reduced, from 23.22 Mgal/d for baseline conditions to 5.59 Mgal/d for drought conditions (table 7). This recharge estimate is considerably less than the sustainable yield of $17 \mathrm{Mgal} / \mathrm{d}$ set in the 2008 WRPP (State of Hawai 'i, 2008). Other large areas of zero recharge occur in the Hāwi aquifer system and the Ka Lae aquifer systems.

\section{Replacement of Alien Forest with Native Forest}

In general, native forests transpire less water than alien and mixed forests (see "Pan Coefficients" section). To analyze the effect of replacing alien forest species with native forest species, the alien forest and mixed native/alien forest land-cover categories were replaced by open native forest (table 4) in the 2008 land-cover map. Otherwise, the water-budget model was run under baseline conditions. Little change in groundwater recharge is observed for most aquifer systems (table 7). However, in every aquifer system in which alien and/or mixed forest were replaced, there is an increase in recharge. The three aquifer systems with the largest increases are Honoka' a, Hāwī, and $\mathrm{Pa}$ 'auilo, with increases of 12,11 , and 10 percent, respectively.

\section{Future Urbanization}

Analysis of the effect of future urbanization on the Island of Hawai'i made use of Hawai 'i County zoning maps
(County of Hawai 'i, 2007) and the Land Use and Pattern Allocation Guide (LUPAG) (County of Hawai' 'i, 2005). For the Urbanization I simulation (table 7), all parcels on the Hawai 'i County zoning maps designated for an urban use were given a low-intensity-developed land-cover code (table 4) and superimposed on the baseline 2008 land-cover map. For the Urbanization II simulation (table 7), all parcels in the LUPAG designated for an urban use were given a low-intensitydeveloped land-cover code (table 4) and superimposed on the baseline 2008 land-cover map. The water-budget model was then run using the same rainfall conditions as in the baseline simulation.

Because the areas of the urban parcels are very small compared to the overall areas of the aquifer systems, little change in recharge occurs as a result of simulated future urbanization on an aquifer-system basis (table 7). Although the water-budget model tends to enhance recharge for urban land covers because of associated irrigation, cesspool leakage, and water-main leakage, these effects simply are on a spatial scale too small to be fully described in this regional study. Enhancement of recharge in urban areas is consistent with the analysis of Shade and Nichols (1996) for southern O'ahu. However, considerable uncertainty exists in the estimation of recharge for urban areas. In urban areas with storm-drain systems, the water-budget model likely overestimates recharge because the capture of runoff from impervious areas by storm drains is not included in the model.

\section{Climate Change}

Analysis of the effect of climate change on the Island of Hawai' $i$ made use of published rainfall projections. Timm and Diaz (2009) used statistical downscaling to estimate changes in seasonal rainfall across the Hawaiian Islands during the late 21 st century. These estimates were based on an ensemble of climate models and emission projections 


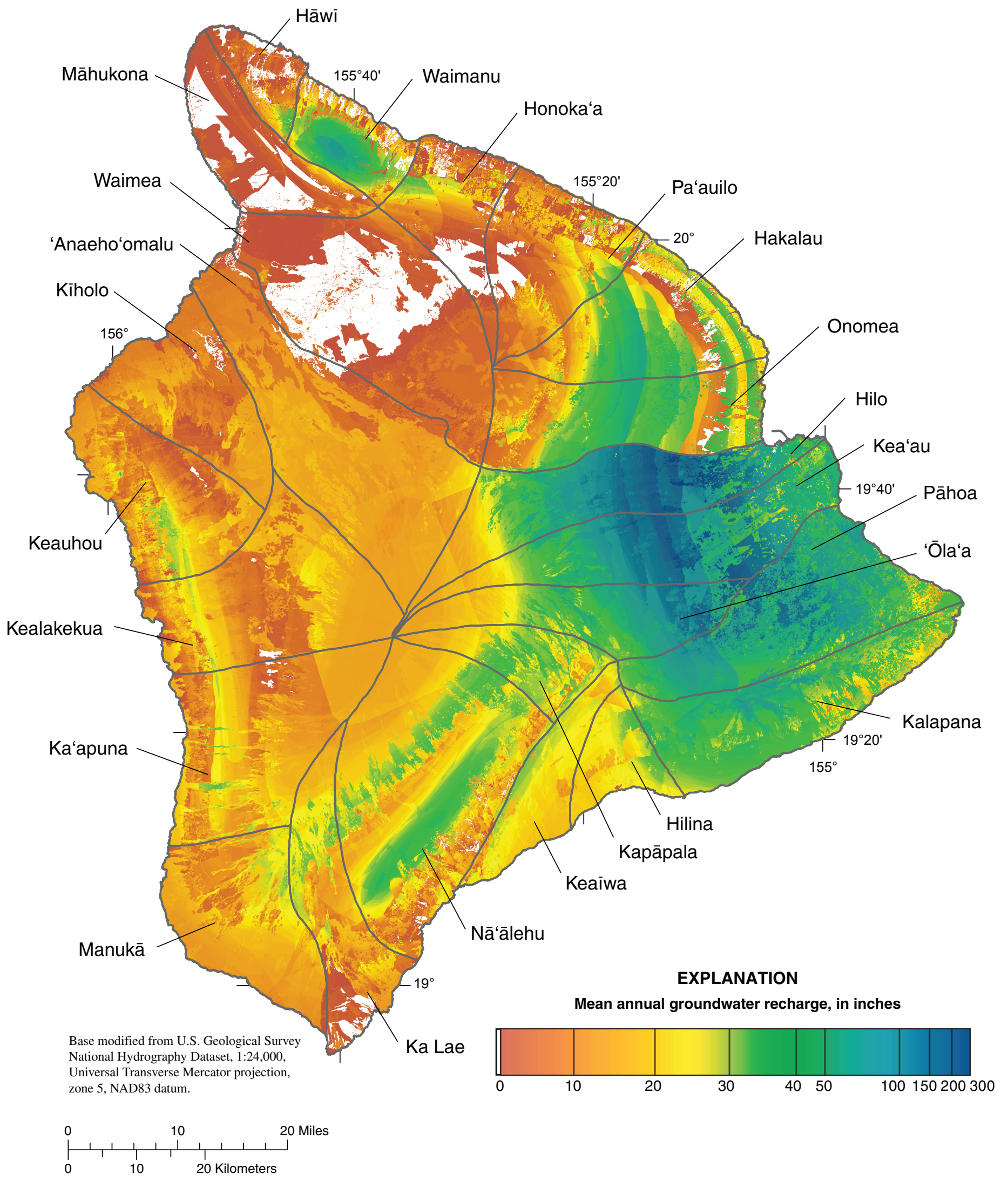

Figure 16. Distribution of mean annual groundwater recharge for drought conditions on the Island of Hawai'i calculated using the water-budget model. Areas of zero recharge appear as white. Boundaries of named aquifer systems (State of Hawai $i$, 2008) are shown in gray. 
from the Intergovernmental Panel on Climate Change (IPCC) Fourth Assessment Report (2007). Late-21st-century projections for specific rain-gage stations are published online (Timm and others, 2009). In general, precipitation is projected to increase slightly for most areas of the island. Projected late-21st-century rainfall changes from Timm and others (2009) were applied to each rainfall-variability zone in the water-budget model (table 9), except for zone 7, an area for which no climate-change projections were published.

The effect of climate change on pan evaporation was analyzed for each pan-evaporation zone by developing a linear regression of historical pan evaporation versus historical rainfall for stations in each zone (table 10). For this particular analysis, pan-evaporation and rainfall data were normalized by dividing the annual or monthly observed values by the mean values for the particular pan-evaporation or rain-gage station published in Ekern and Chang (1985) or Giambelluca and others (1986), respectively. For the linear regression, a basic assumption was made that annual or monthly periods of mean pan evaporation should correspond to annual or monthly periods of mean rainfall. Hence, each regression line was forced through the point $(1,1)$ on the plot of normalized pan evaporation versus normalized rainfall. The equation for each regression line is given by

$$
P A N /(P A N)_{\text {mean }}-1=a\left(P / P_{\text {mean }}-1\right)
$$

where

$P A N=$ pan evaporation $[\mathrm{L}]$,

$(P A N)_{\text {mean }}=$ mean pan evaporation $[\mathrm{L}]$,

$a=$ slope of the regression line [dimensionless],

$P=$ rainfall $[\mathrm{L}]$, and

$P_{\text {mean }}=$ mean rainfall $[\mathrm{L}]$.

Solving equation 15 for pan evaporation $(P A N)$ yields:

$$
P A N=\left(a\left(P / P_{\text {mean }}-1\right)+1\right)(P A N)_{\text {mean }}
$$

Late-21st-century mean pan evaporation in each panevaporation zone was estimated by using equation 16 and the following variable definitions:

Table 9. Parameters used for the simulation of late-21st-century rainfall conditions on the Island of Hawai'i.

[See figure 6 for locations of rainfall-variability zones; column (A) is the ratio of mean seasonal rainfall from Timm and others (2009) to the mean seasonal rainfall derived from Giambelluca and others (1986); columns (B), (C), and (D) are estimated rainfall-change factors based on the means and lower and upper margins of the 95-percent statistical confidence interval for a six-model ensemble for the late 21st century from Timm and others (2009); columns (E), (F), and (G) are the factors used to adjust mean rainfall in each rainfall-variability zone in the water-budget model to simulate late 21 st century climate; SKN, state key number; NWS ID, National Weather Service cooperative identification number, HVNP HQ, Hawai'i Volcanoes National Park headquarters; -, no data given in

\begin{tabular}{|c|c|c|c|c|c|c|c|c|c|}
\hline $\begin{array}{c}\text { Rainfall- } \\
\text { variability } \\
\text { zone }\end{array}$ & $\begin{array}{c}\text { Rain-gage } \\
\text { station and } \\
\text { SKN }\end{array}$ & $\begin{array}{c}\text { NWS } \\
\text { ID }\end{array}$ & $\begin{array}{l}\text { Mean } \\
\text { rainfall } \\
\text { adjustment } \\
\text { factor } \\
\text { (A) }\end{array}$ & $\begin{array}{l}\text { Mean } \\
\text { change } \\
\text { factor } \\
\text { (B) }\end{array}$ & $\begin{array}{l}\text { Lower } 95 \% \\
\text { confidence } \\
\text { change } \\
\text { factor } \\
\text { (C) }\end{array}$ & $\begin{array}{l}\text { Upper } 95 \% \\
\text { confidence } \\
\text { change } \\
\text { factor } \\
\text { (D) }\end{array}$ & $\begin{array}{c}\text { Overall } \\
\text { adjustment } \\
\text { factor for } \\
\text { mean change } \\
(E)=(A) \times(B)\end{array}$ & $\begin{array}{c}\text { Overall } \\
\text { adjustment } \\
\text { factor for lower } \\
95 \% \text { confidence } \\
\text { change } \\
\text { (F) }=(A) \times(C)\end{array}$ & $\begin{array}{c}\text { Overall } \\
\text { adjustment } \\
\text { factor for upper } \\
95 \% \text { confidence } \\
\text { change } \\
\text { (G) }=(A) \times(D)\end{array}$ \\
\hline \multicolumn{10}{|c|}{ Wet Season (November to April) } \\
\hline 1 & Hāwī 168 & 511339 & 1.070 & - & - & - & 1.070 & 1.070 & 1.070 \\
\hline 2 & Pa'auilo 221 & 517312 & 0.996 & 1.033 & 0.852 & 1.214 & 1.029 & 0.849 & 1.209 \\
\hline 3 & HVNP HQ 54 & 511303 & 1.056 & 1.028 & 0.890 & 1.166 & 1.086 & 0.940 & 1.232 \\
\hline 4 & Nā‘ālehu 14 & 516588 & 0.998 & 1.027 & 0.860 & 1.195 & 1.025 & 0.858 & 1.193 \\
\hline 5 & Kūlani Mauka 76 & 515018 & 0.975 & - & - & - & 0.975 & 0.975 & 0.975 \\
\hline 6 & Hōlualoa 70 & 511557 & 1.089 & 1.012 & 0.799 & 1.226 & 1.102 & 0.870 & 1.335 \\
\hline 7 & No estimates for this & zone & - & - & - & - & 1.000 & 1.000 & 1.000 \\
\hline \multicolumn{10}{|c|}{ Dry Season (May to October) } \\
\hline 1 & Hāwī 168 & 511339 & 1.014 & 1.040 & 0.818 & 1.261 & 1.054 & 0.829 & 1.279 \\
\hline 2 & Pa‘auilo 221 & 517312 & 0.941 & 1.070 & 0.839 & 1.300 & 1.007 & 0.790 & 1.224 \\
\hline 3 & HVNP HQ 54 & 511303 & 1.011 & - & - & - & 1.011 & 1.011 & 1.011 \\
\hline 4 & Kapāpala Ranch 36 & 513300 & 1.009 & 1.039 & 0.867 & 1.212 & 1.048 & 0.875 & 1.223 \\
\hline 5 & Kūlani Mauka 76 & 515018 & 0.847 & - & - & - & 0.847 & 0.847 & 0.847 \\
\hline 6 & Hōlualoa 70 & 511557 & 1.097 & 1.044 & 0.843 & 1.244 & 1.145 & 0.924 & 1.364 \\
\hline 7 & \multicolumn{2}{|c|}{ No estimates for this zone } & - & - & - & - & 1.000 & 1.000 & 1.000 \\
\hline
\end{tabular}
Timm and others (2009)] 
$P A N=$ late-21st-century mean pan evaporation $[\mathrm{L}]$, $(P A N)_{\text {mean }}=$ mean pan evaporation based on Ekern and Chang (1985) [L],

$a=$ slope of the regression line for the panevaporation zone (table 10) [dimensionless],

$P=$ late-21st-century mean rainfall based on Timm and others (2009) [L], and

$P_{\text {mean }}=$ mean rainfall based on Giambelluca and others (1986) [L].

As shown in table 10, the slope of the linear regression is negative in each zone, supporting a basic assumption that rainfall and pan evaporation are inversely related. However, the coefficients of determination for the linear regressions generally are low, implying that relations between pan evaporation and rainfall are poor. These relations generally are poor regardless of whether monthly or annual rates are used. Given the lack of other reliable information for projecting future pan evaporation, it was decided to use the pan evaporation/rainfall relations in table 10, despite the low coefficients of determination. Using these equations creates additional uncertainty in projected recharge, but the inverse relation between rainfall and pan evaporation is preserved.

For the climate-change simulations (table 7, fig. 17), the same land cover was used as in the Urbanization II scenario to account for the increased urbanization that will likely have occurred by the end of the 21 st century. All parcels in the LUPAG designated for an urban use were given a lowintensity-developed land-cover code (table 4) and superimposed on the baseline 2008 land-cover map. The water-budget model was then run using projected late-21st-century rainfall and pan-evaporation conditions based on the upper margin of the 95-percent confidence interval (climate change I), mean (climate change II), and lower margin of the 95-percent confidence interval (climate change III) of the six-model ensemble from Timm and others (2009).

Except for 'Anaeho'omalu, recharge estimates from the climate-change-II simulation (mean scenario) are the same as or higher than the baseline estimates for each aquifer system (table 7), with the average difference being about 8 percent. Recharge estimates for the climate-change-III simulation (lower 95-percent scenario) are lower than the baseline estimates for all but the Hāwī aquifer system, which is only 1.5 percent higher. In all aquifer systems, the recharge estimates for the drought scenario are substantially lower than the estimates for the climate-change-III scenario, with the average difference being about 13 percent.

\section{Kona-Area Submodel}

\section{Historical}

\section{4-2008}

The water budget for the Kona area during the time period 1984-2008 was estimated using 5 scenarios, each 5 years in duration: 1984-88, 1989-93, 1994-98, 1999-2003, and 2004-8. The highest mean recharge, $538 \mathrm{Mgal} / \mathrm{d}$, occurred during the 2004-8 period, whereas the lowest mean recharge, $270 \mathrm{Mgal} / \mathrm{d}$, occurred during the 1999-2003 period (fig. 18; table 11). These extremes coincided with the periods

Table 10. Linear-regression statistics for normalized pan evaporation versus normalized rainfall used for the climatechange analysis for the Island of Hawai'i.

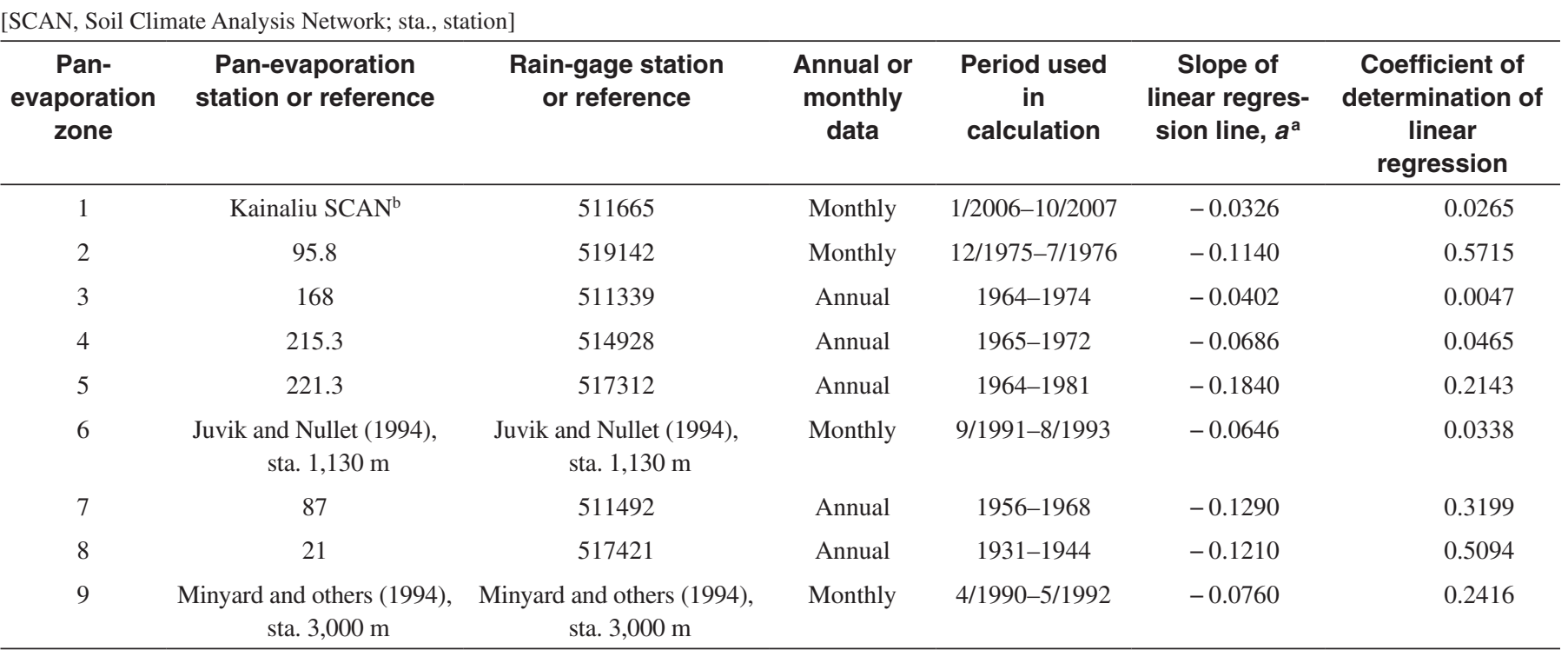

\footnotetext{
${ }^{a}$ Regression lines were forced through the point $(1,1)$ such that periods with mean rainfall would coincide with mean pan evaporation. Slope is dimensionless.

bSolar-radiation data from the Kainaliu SCAN station were used to develop a relation with pan evaporation based on pan-evaporation maps from Ekern and Chang (1985).
} 

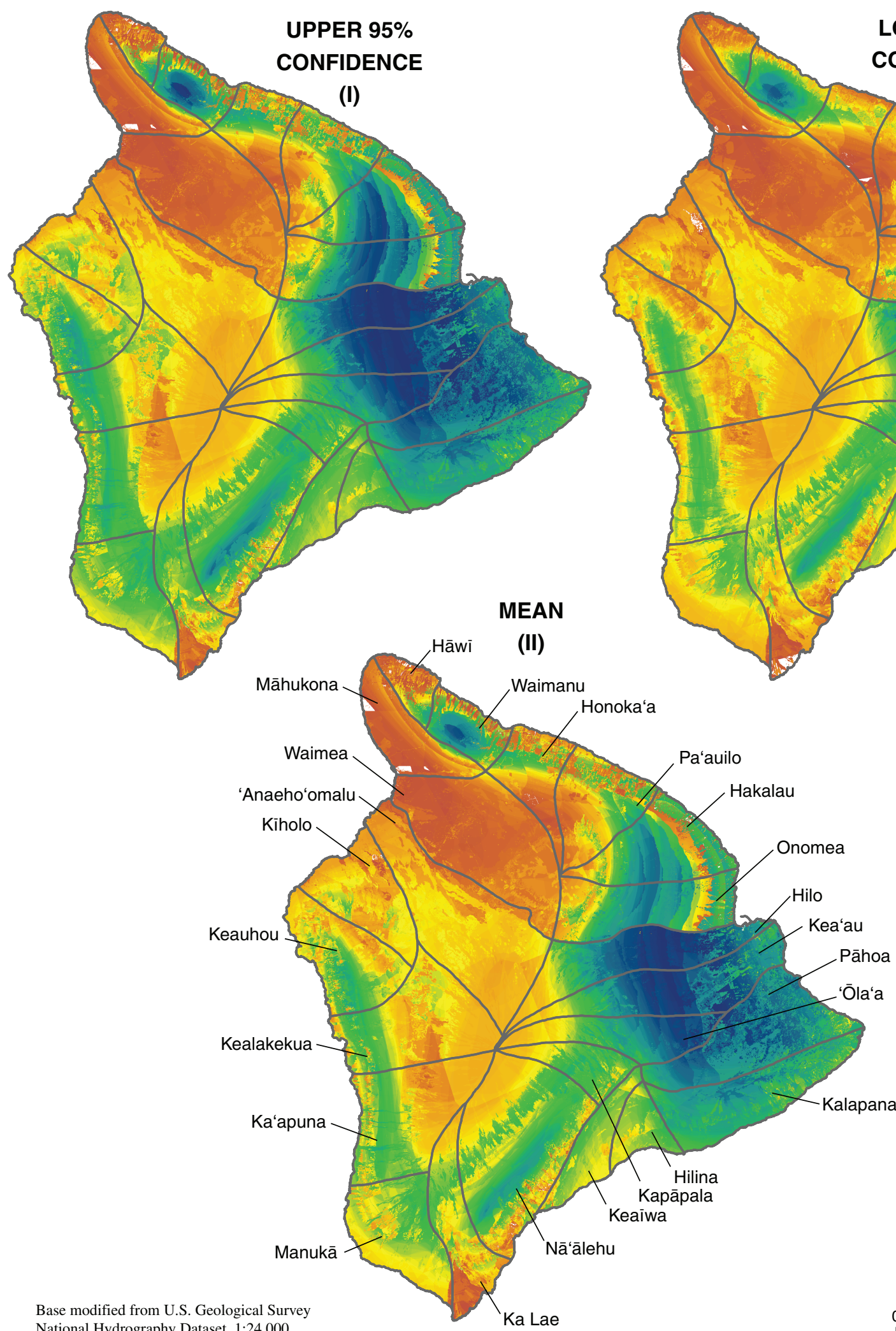

National Hydrography Dataset, 1:24,000,

Universal Transverse Mercator projection, zone 5, NAD83 datum.

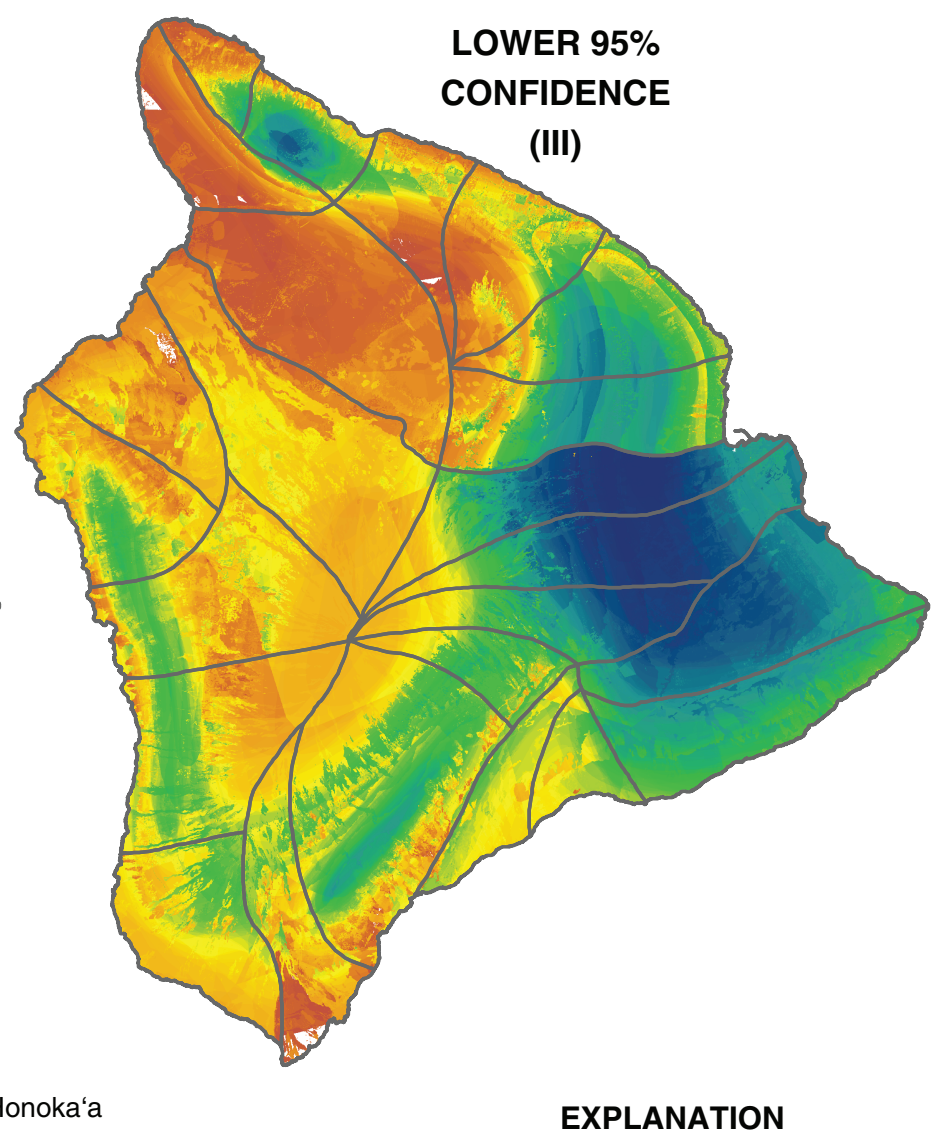

Mean annual groundwater recharge, in inches

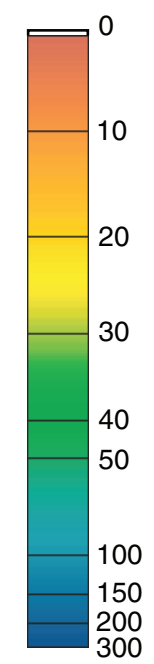

Figure 17. Three possible distributions of mean annual groundwater recharge during the late 21 st century based on the mean (II) and the upper (I) and lower (III) margins of the 95-percent confidence interval of the projected rainfall changes from the six-model ensemble in Timm and others (2009). Areas of zero recharge appear as white. Boundaries of named aquifer systems (State of Hawai'i, 2008) are shown in gray. 
of highest and lowest mean rainfall, 1,152 Mgal/d and 755 $\mathrm{Mgal} / \mathrm{d}$, respectively.

On a monthly basis, average recharge was highest in January, $604 \mathrm{Mgal} / \mathrm{d}$, and lowest in August, $287 \mathrm{Mgal} / \mathrm{d}$ (table 12). Interestingly, these extremes do not coincide with the months of highest and lowest rainfall or total water inflowthe sum of rainfall, fog interception, and irrigation. The extremes do, however, relate inversely to the general seasonal trend in ET, with ET being lower in the winter and higher in the summer. Despite this particular inverse relation, no overall seasonal pattern in recharge is discernible.

The spatial distributions of mean annual recharge in the Kona area for the time periods spanning 1984-2008 (fig. 19) indicate that the highest recharge occurs in a belt about 4 miles wide running parallel to the coast about 2 miles inland. The relative spatial distribution of recharge remains fairly consistent throughout the five time periods, with the magnitude of recharge changing depending on the magnitude of rainfall during the period (table 11).

\section{Hypothetical Scenarios}

\section{Baseline}

Baseline groundwater recharge for the Kona-area submodel was calculated using 2008 land cover, which was modified from U.S. Geological Survey (2006) and rainfall from the period 1984-2008. The baseline scenario was designed to simulate mean conditions over the 1984-2008 time period and be used as a basis of comparison for other hypothetical scenarios.

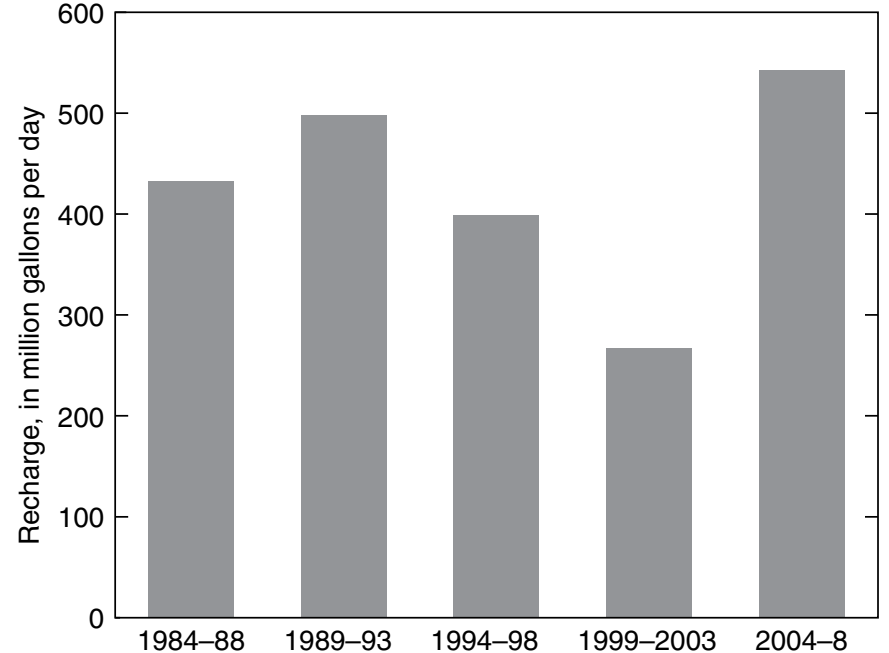

Figure 18. Estimated groundwater recharge during five historical time periods for the Kona area of the Island of Hawai í.

\section{Drought Conditions}

Analysis of the effect of drought conditions in the Kona area made use of the rainfall-variability gages described in the "Rainfall" section of this report (fig. 6). The average ratio of observed to mean annual rainfall for the eight rainfall-variability gages was computed for each year during the period 19842008 (fig. 20), and the time period with the lowest 5-year average rainfall, 1998-2002, was selected as the drought period. To estimate recharge during drought conditions in the Kona

Table 11. Mean annual water-budget estimates for selected historical and hypothetical land-cover and rainfall conditions in the Kona area of the Island of Hawai'i.

[Mgal/d, million gallons per day; Irr, irrigation; DR direct recharge; RO, runoff; ET, evapotranspiration exclusive of canopy evaporation; CEvap, canopy evaporation from forested areas, Rech, recharge; LUPAG, Land Use Pattern Allocation Guide (County of Hawai ' $\mathrm{i}$, 2005)]

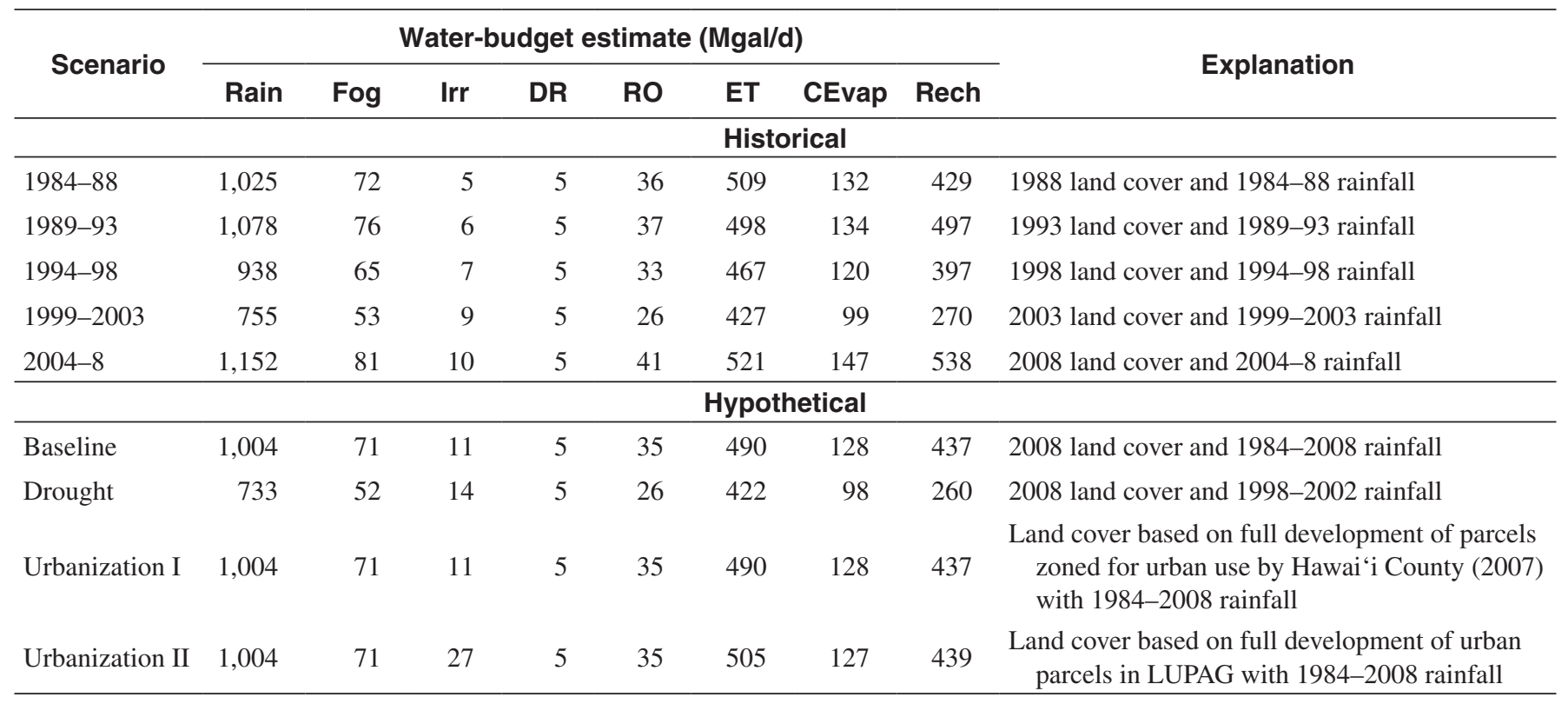




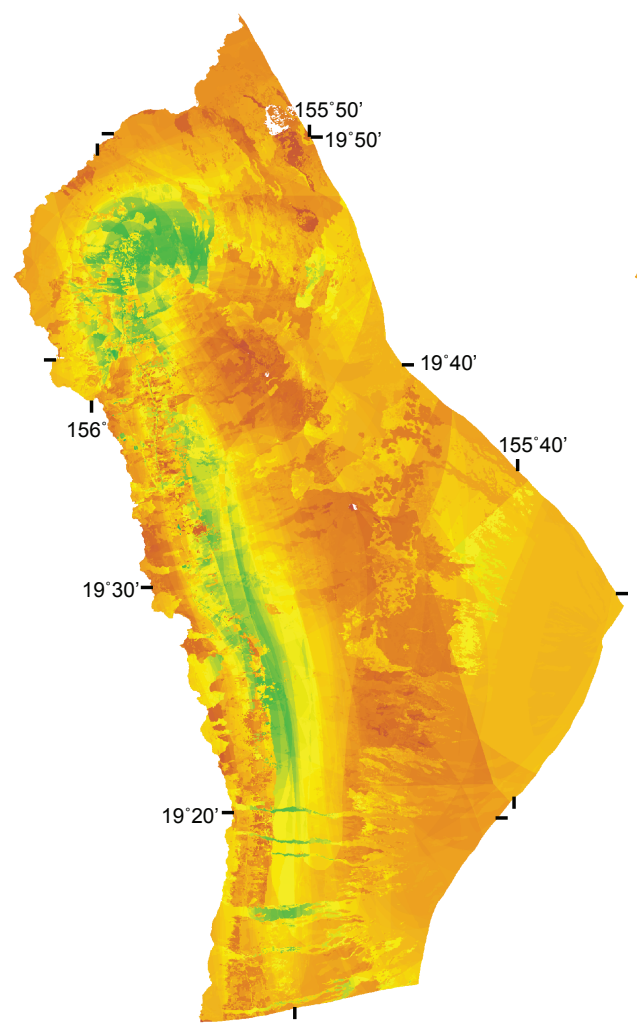

1984-88

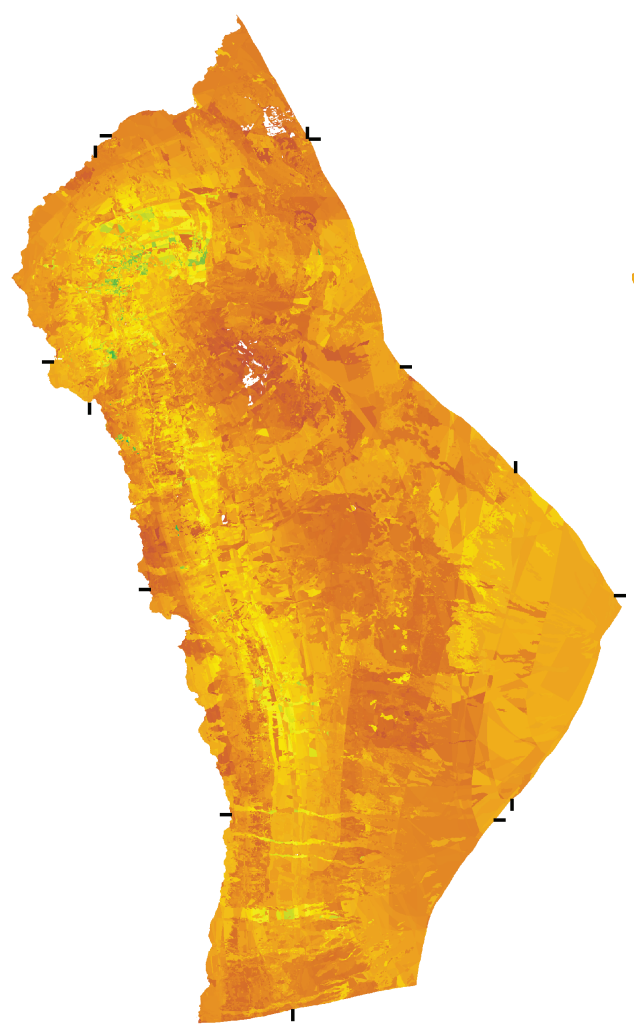

1999-2003

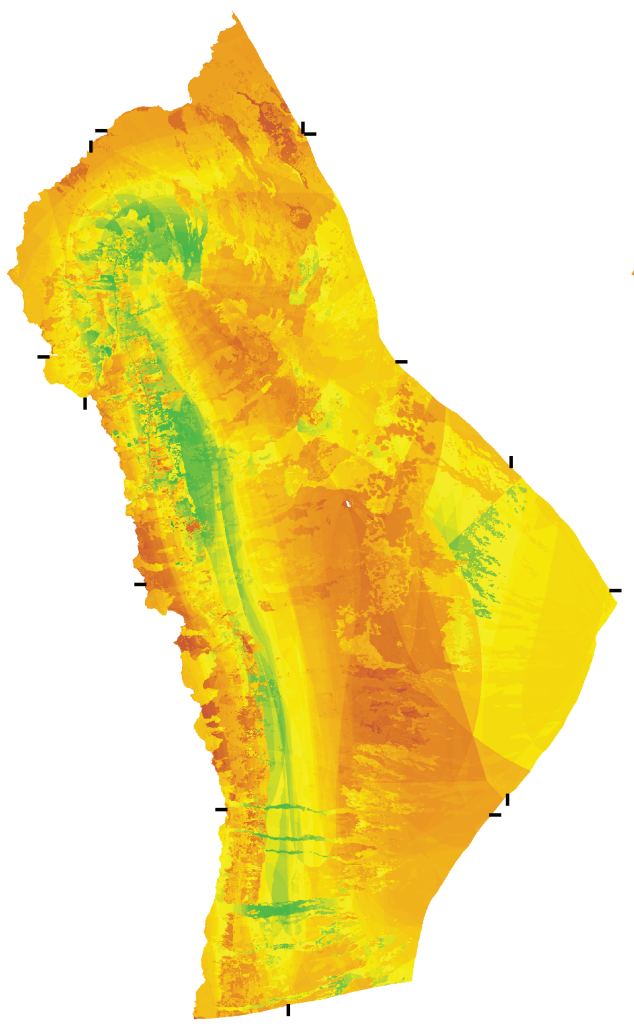

1989-93

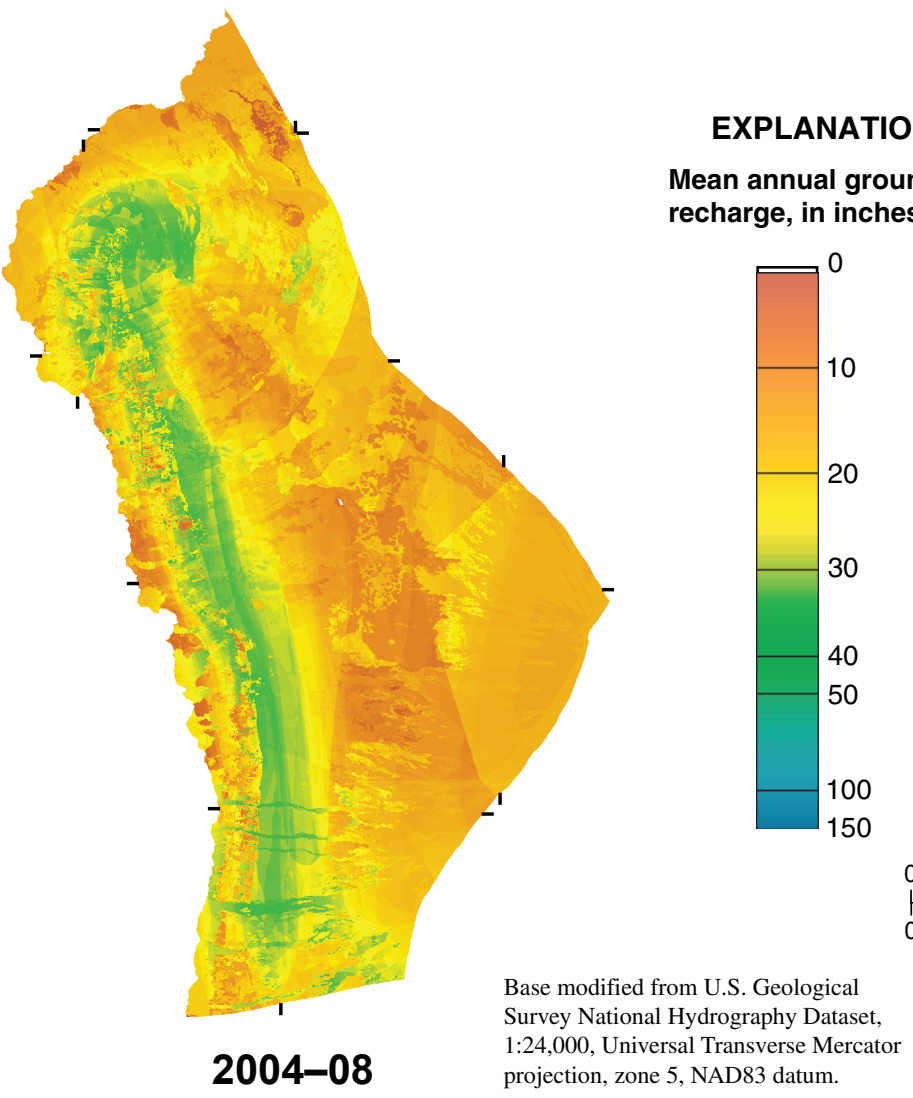

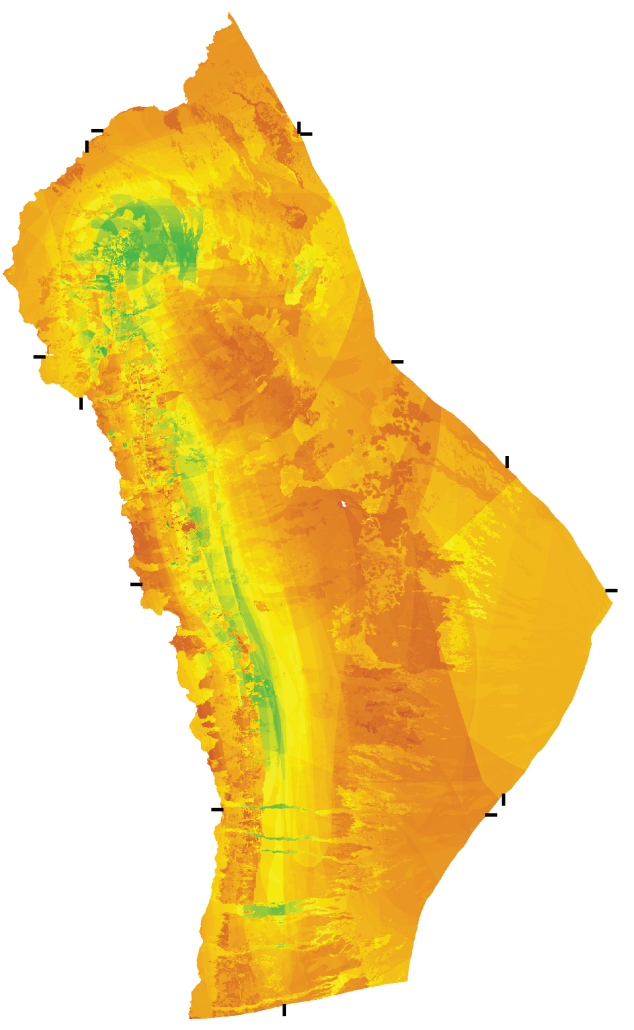

1994-98

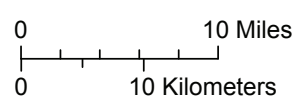

Figure 19. Distribution of estimated mean annual groundwater recharge during five time periods between 1984 and 2008 calculated using the water-budget model for the Kona area of the Island of Hawai'i. Areas of zero recharge appear as white. 
Table 12. Mean monthly water budgets during five time periods for the Kona area of the Island of Hawai'i.

[Mgal/d, million gallons per day; evapotranspiration is inclusive of canopy evaporation in forests; positive values for change in moisture storage indicate an increase in moisture and negative values indicate a decrease in moisture; direct recharge occurs at a uniform monthly rate of $5 \mathrm{Mgal} / \mathrm{d}$ during all periods]

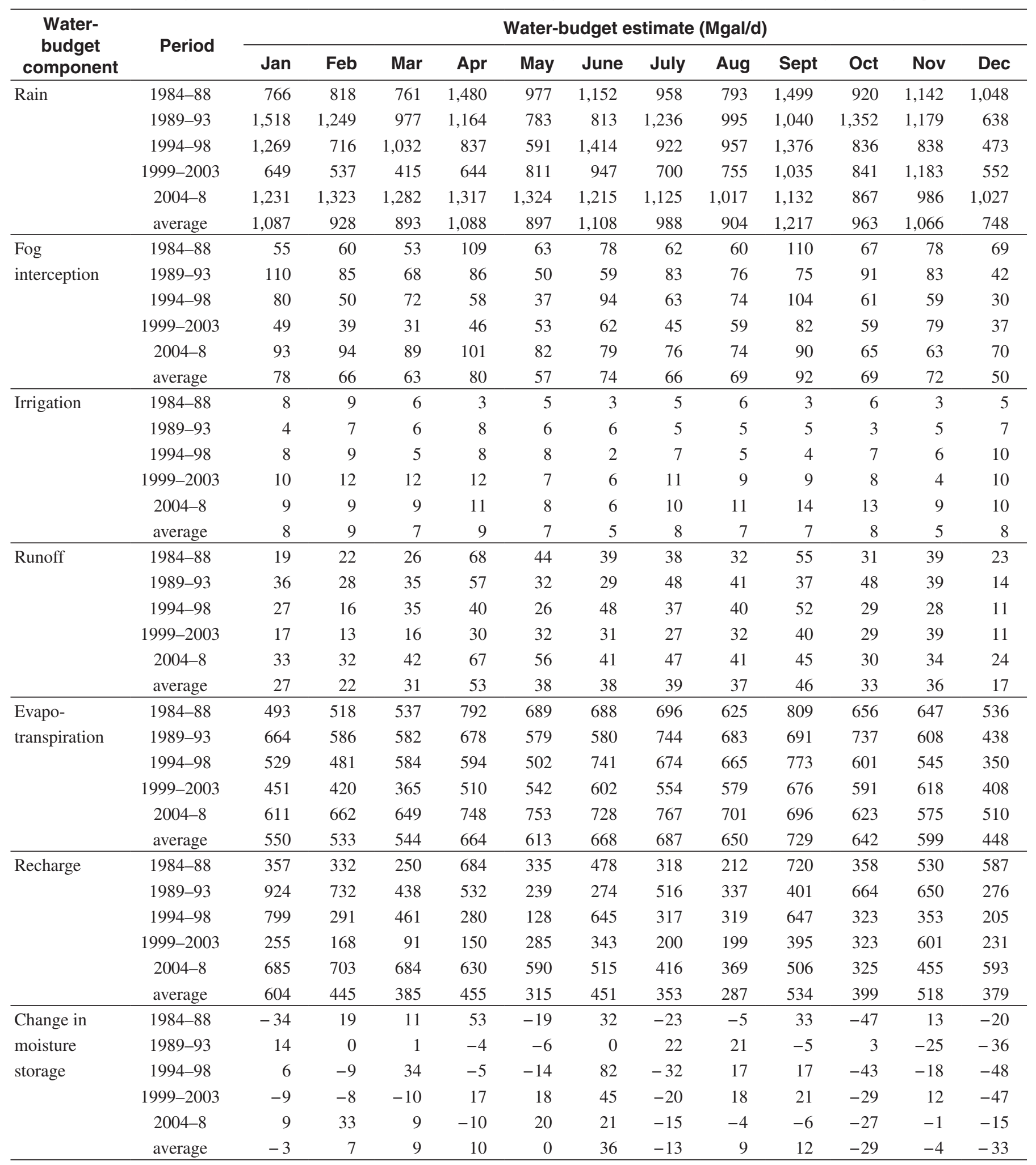


area, the water-budget model was run using 2008 land cover and rainfall from the period 1998-2002. Mean groundwater recharge for drought conditions was estimated to be 41 percent lower than baseline recharge (table 11).

\section{Future Urbanization}

Analysis of the effect of future urbanization in the Kona area made use of Hawai'i County zoning maps (County of Hawai 'i, 2007) and the LUPAG (County of Hawai' $i, 2005)$. For the Urbanization I simulation (table 11), all parcels on the Hawai'i County zoning maps designated for an urban use were given a low-intensity-developed land-cover code (table 4) and superimposed on the baseline 2008 land-cover map. For the Urbanization II simulation (table 11), all parcels in the LUPAG designated for an urban use were given a low-intensity-developed land-cover code (table 4) and superimposed on the baseline 2008 land-cover map. The water-budget model was then run using the same rainfall conditions as in the Konaarea baseline simulation.

Because the areas of the urban parcels are very small compared to the overall areas of the aquifer systems, little change in recharge occurs as a result of future urbanization on a regional basis (table 11). Although the water-budget model tends to enhance recharge for urban land covers because of associated irrigation, cesspool leakage, and water-main leakage, these effects are on a spatial scale simply too small to be fully described in this regional study. In urban areas with storm-drain systems, the water-budget model for this study likely overestimates recharge because the capture of runoff from impervious areas by storm drains is not included in the model.

\section{Climate Change}

Because of an insufficient number of rainfall-change projections in Timm and others (2009) for gages in the Kona area, the Kona-area submodel was not used for climate-change estimation. Climate-change projections for the aquifer systems in the Kona area-Kiholo, Keauhou, Kealakekua, and Ka'apunawere obtained using the islandwide model (table 7).

\section{Sensitivity Analysis}

Uncertainty exists in many of the water-budget inputs used in this study. The values used in the water-budget model were deemed to be those most reasonable. To analyze the

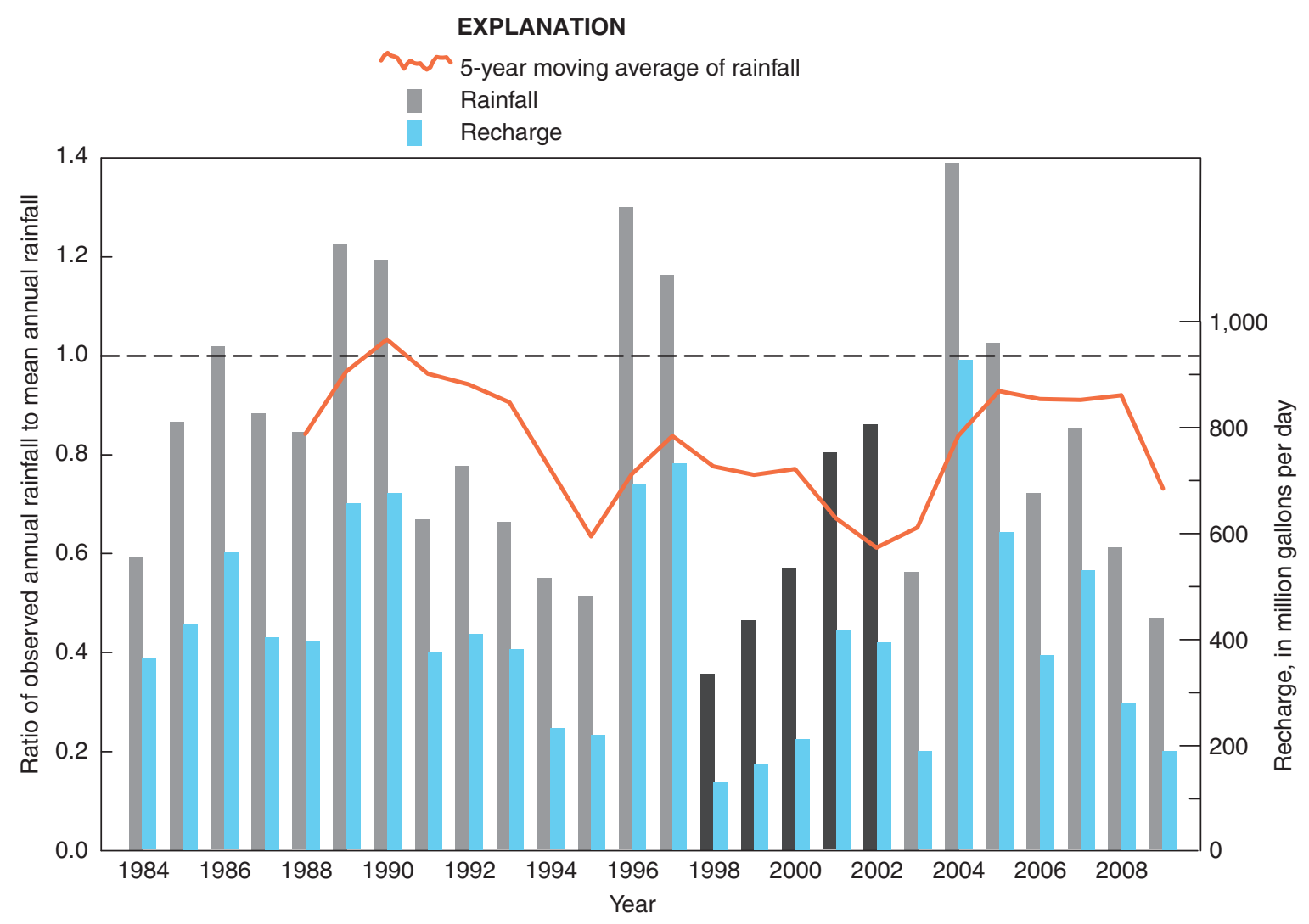

Note: Darker bars represent the period with the lowest 5-year average rainfall, used to simulate drought. Mean rainfall is from Giambelluca and others (1986) for the period 1916-83.

Figure 20. Average ratio of observed to mean annual rainfall for the eight gages used to simulate historical rainfall for the Kona-area water-budget submodel. See figure 6 for rain-gage locations. 
Table 13. Results of sensitivity testing for selected water-budget parameters performed for Onomea, Keauhou, and Waimea aquifer systems on the Island of Hawai'i.

[See figure 2 for the locations of the Onomea, Keauhou, and Waimea aquifer systems]

\begin{tabular}{|c|c|c|c|c|}
\hline \multirow[b]{2}{*}{ Parameter } & \multirow{2}{*}{$\begin{array}{l}\text { Adjusted parameter } \\
\text { value }\end{array}$} & \multicolumn{3}{|c|}{ Percent difference in recharge relative to baseline estimate } \\
\hline & & $\begin{array}{c}\text { Onomea aquifer } \\
\text { system }\end{array}$ & $\begin{array}{c}\text { Keauhou aquifer } \\
\text { system }\end{array}$ & $\begin{array}{c}\text { Waimea aquifer } \\
\text { system }\end{array}$ \\
\hline Available water capacity & High reported value ${ }^{a}$ & -0.5 & -2.2 & -8.5 \\
\hline Fog-catch efficiency & $150 \%$ of baseline & 16.8 & 1.9 & 6.5 \\
\hline \multirow[t]{2}{*}{ Ratio of fog interception to rainfall } & $150 \%$ of baseline & 16.6 & 2.0 & 6.4 \\
\hline & $50 \%$ of baseline & -16.9 & -1.9 & -6.1 \\
\hline \multirow[t]{2}{*}{ Root depth } & $150 \%$ of baseline & -1.3 & -2.8 & -19.3 \\
\hline & $50 \%$ of baseline & 2.4 & 4.6 & 47.6 \\
\hline Pan coefficient & $80 \%$ of baseline & 1.4 & 4.5 & 15.4 \\
\hline \multirow[t]{2}{*}{$\begin{array}{l}\text { Net-precipitation rate in forests } \\
\text { (as percentage of rainfall) }\end{array}$} & $\begin{array}{l}20 \text { percentage units higher } \\
\text { than baseline }\end{array}$ & 33.1 & 14.5 & 6.0 \\
\hline & $\begin{array}{l}20 \text { percentage units lower } \\
\text { than baseline }\end{array}$ & -25.3 & -13.1 & -4.4 \\
\hline
\end{tabular}

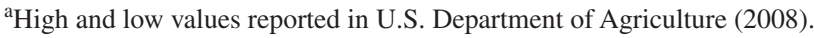

effect that uncertainty in water-budget inputs has on estimated recharge, the water budget was rerun while changing one input value at a time within a reasonable range. A range of recharges for each test was computed by holding all other inputs at their original values and varying the test input. For three aquifer systems representative of three important climate regions on the Island of Hawai ' $i$, the resulting recharge estimates were compared to baseline recharge (table 13). Onomea aquifer system is representative of windward areas of the island with forested land cover and high, primarily orographic rainfall; Keauhou aquifer system is representative of the Kona area, with mixed forest and grassland land cover and moderate, primarily convective rainfall; and Waimea aquifer system is representative of leeward areas of the island with pasture and grassland and low rainfall. The parameters tested were (1) available water capacity, (2) fog-catch efficiency, (3) ratio of fog interception to rainfall, (4) root depth, (5) ratio of runoff to rainfall, (6) pan coefficient, and (7) the net-precipitation rate in forests. For most parameters, baseline values were increased by 50 percent and decreased by 50 percent. For available water capacity, the range chosen for testing was between the high and low values published in U.S. Department of Agriculture (2008). For pan coefficients, baseline values were increased by 20 percent and decreased by 20 percent. For the net-precipitation rate in forests, which is measured as a percentage of rainfall, baseline values were increased by 20 percent and decreased by 20 percent.

For the Onomea aquifer system, the parameter with the largest effect on recharge is the ratio of runoff to rainfall (table 13). This result is not surprising, given the very large amount of runoff that occurs in this area. Because of the large amount of forested area, it is also not surprising that changes to the net-precipitation rate had a large effect. Changes to the fog-efficiency ratio and ratio of fog interception to rainfall had substantial effects, owing to the large amount of forested area within the fog zone and the high mean annual rainfall. Increasing the pan coefficient also had a considerable effect. Changes to root depth and available water capacity had smaller effects-less than 10 percent-on groundwater recharge.

For the Keauhou aquifer system, the parameters with the largest effect on recharge are the pan coefficient and the netprecipitation rate (table 13). This result indicates the important role of ET and forests in the overall Kona-area water budget. The other parameters have small effects-less than 10 percent-on groundwater recharge.

For the Waimea aquifer system, the parameter with the largest effect on recharge is root depth (table 13). This result indicates the importance of moisture-storage capacity, which is directly related to root depth, and shows that it is extremely important in leeward areas of the island where rainfall 
commonly is light and sporadic and grass roots are relatively deep. The pan coefficient also has a substantial effect, indicating the importance of ET for this region of the island. Changes to available water capacity have the largest effects in the Waimea aquifer system, compared to the other two systems tested. This is further indication of the importance of moisture-storage capacity to the water budget of the area. The other parameters have small effects-less than 10 percenton groundwater recharge.

\section{Suggestions for Future Study and Additional Data Collection}

The water-budget model described in this report is limited by the quality, density, and availability of data needed to develop model input-land cover, rainfall, fog interception, irrigation, runoff, soil properties, and ET. Continued research into all of these subjects would improve overall confidence in recharge estimates. Updated rainfall distribution maps, using more recent data, would certainly increase the accuracy of recharge calculations. A better understanding of fog interception and continued research into the calibration of mechanical fog catch to different forest types would be useful. More continuous-record stream-gaging stations from which to gather data relevant to developing runoff estimates and relations to rainfall and other parameters would increase the accuracy of recharge estimates, especially in wet areas, as shown in the section on "Sensitivity Analysis." Updated soil maps that include better information for nonagricultural areas would be useful. More research into the ET properties of different forest types would also be useful and could produce better pan-coefficient values and net-precipitation rates, which are very important in the Kona Area, as shown in the "Sensitivity Analysis" section. The ET properties of sparsely vegetated land, which on the Island of Hawai' $i$ generally means bare lava flow, remain uncertain. This landcover category makes up a large fraction of the island (fig. 4). Improved information on root depths would be useful, especially in the leeward Kohala and leeward Mauna Kea areas, where the sensitivity analysis shows the importance of this parameter. Investigation into recharge through streambeds would also be very useful, especially in the Māhukona and Waimea aquifer systems. Reaches of several streams in this area flow perennially at high elevations. Flows in these streams diminish as they traverse the Māhukona and Waimea aquifer systems, becoming intermittent before they reach the coast. Most of this loss in flow is due to seepage into the streambed. A study of urban runoff is needed, because that would help partition the volume of rain that falls on impervious surfaces into flows to dry wells, storm drains, and pervious surfaces. This would increase the confidence of urban-recharge estimates.

The estimation of recharge using methods other than a water budget could provide an important comparison. The nature of groundwater recharge in Hawai' $i$ is such that direct regional measurements are not possible at this time. As such, the water-budget model cannot be calibrated in a traditional manner. One way to gain confidence in recharge estimates from this model would be to compare them to recharge estimates from another method. Unfortunately, most rechargeestimation methods used on continents are ineffective for the Hawaiian Islands. However, studies using chloride mass balance, stable isotopes of water, and geophysical methods may produce some data that are usable for comparison to model results.

\section{Summary and Conclusions}

Concern surrounding increasing demand for groundwater on the Island of Hawai ' $\mathrm{i}$, caused by a growing population and an increasing reliance on groundwater as a source for municipal and private water systems, has prompted a study of groundwater recharge on the island using the most current data and accepted methods. This report documents the development of a daily water-budget model for computing groundwater recharge on the Island of Hawai ' $i$ and the application of the model to estimate mean recharge for various land-cover and rainfall conditions. A submodel for the Kona area was developed and applied to estimate historical groundwater recharge in the Kona area during the period 1984-2008. Recharge estimates from this study were compared to recharge estimates in the 2008 Water Resource Protection Plan (WRPP) (State of Hawai 'i, 2008), and the sensitivity of recharge estimates to selected water-budget parameters was evaluated.

Estimated mean annual recharge for baseline conditions on the Island of Hawai ' $\mathrm{i}$ is $6,594 \mathrm{Mgal} / \mathrm{d}$, which is about 49 percent of rainfall. Baseline conditions for this study were 2008 land cover and mean annual rainfall from the period 1916-83. Recharge is highest on the windward slopes of Mauna Loa below the tradewind inversion and lowest on the leeward slopes of Kohala and Mauna Kea. Local recharge maxima also occur on (1) the higher elevations of windward Kohala, (2) windward Mauna Kea below the tradewind inversion, (3) windward Kîlauea, (4) the middle elevations of southeastern Mauna Loa, and (5) the lower middle elevations of leeward Mauna Loa and southwestern Hualālai, in the Kona area. Local recharge minima also occur on (1) Mauna Kea and Mauna Loa, above the tradewind inversion, (2) the northern tip of Kohala, (3) leeward Kîlauea, (4) the southern tip of Mauna Loa, and (5) the northwestern slopes of Mauna Loa and Hualālai.

Analysis of estimated recharge with respect to land cover reveals some results that may be inconsistent with popular notions. Because of potentially high rates of canopy evaporation, forested land does not necessarily provide more recharge than grassland or agricultural land. Urban land appears to enhance recharge because of irrigation, cesspool 
leakage, and water-main leakage. However, the water-budget model likely overestimates recharge for urban areas with storm-drain systems, because the capture of runoff from impervious areas by storm drains is not included in the model.

In 18 of the 24 aquifer systems on the island, mean annual recharge estimated in this study for baseline conditions was higher than the recharge estimates used in the 2008 WRPP. The higher estimates in this study generally are attributable to differences in the methods used to estimate runoff and evapotranspiration, the inclusion of fog interception in this study, and the shorter computational time step used in this study. The substantially lower estimates of recharge in this study for the Māhukona, Waimea, and Hāwī aquifer systems - 38, 34, and 29 percent lower, respectively-compared to the estimates used in the 2008 WRPP may be of concern. These areas are experiencing a growth in development and a related growth in demand for water. For the drought simulation, which used historical rainfall from the period 1991-95, the estimates of recharge for all three of these aquifer systems were substantially less than the sustainable yields of the aquifer systems set by CWRM.

Recent projections of rainfall change owing to effects of ongoing climate change generally indicate a slight increase in islandwide rainfall, and estimates of annual recharge in the late 21 st century are higher than baseline estimates for every aquifer system, except 'Anaeho'omalu. On average, these aquifer-system recharge estimates are higher by about 8 percent compared to baseline estimates.

In the Kona area, groundwater recharge was highest during 2004-8 and lowest during 1999-2003. These extremes in recharge coincided with the periods of highest and lowest rainfall, respectively. On a monthly basis, average recharge during 1984-2008 was highest in January and lowest in August; however, no seasonal pattern is discernible. Spatially, the highest recharge occurred in a belt about 4 miles wide running parallel to the coast about 2 miles inland.

Sensitivity of recharge estimates to input parameters is related to the climate and land-cover conditions of the particular area of study. For the wet, forested areas characteristic of the windward side of the island, recharge was most sensitive to the ratio of runoff to rainfall. For the dry, grassland areas characteristic of the northwestern leeward side of the island, recharge was most sensitive to root depth. For the Kona area, characterized by moderate rainfall and a wide variety of land cover, recharge was very sensitive to pan coefficients and the net-precipitation rate in forests.

\section{References Cited}

Allen, R.G., Pereira, L.S., Raes, Dirk, and Smith, Martin, 1998, Crop evapotranspiration; guidelines for computing crop water requirements: Food and Agriculture Organization of the United Nations, FAO Irrigation and Drainage Paper 56, 300 p.
Asner, G.P., Hughes, R.F., Vitousek, P.M., Knapp, D.E., Kennedy-Bowdoin, Ty, Boardman, Joseph, Martin, R.E., Eastwood, Michael, and Green, R.O., 2008, Invasive plants transform the three-dimensional structure of rain forests: Proceedings of the National Academy of Sciences, v. 105, no. 11, p. 4519-4523.

Bartolino, J.R., 2007, Assessment of areal recharge to the Spokane Valley-Rathdrum Prairie aquifer, Spokane County, Washington, and Bonner and Kootenai Counties, Idaho: U.S. Geological Survey Scientific Investigations Report 2007-5038, 38 p.

Bean, Christine, Juvik, J.O., and Nullet, Dennis, 1994, Mountain evaporation profiles on the island of Hawai ' $i$ : Journal of Hydrology, v. 156, nos. 1-4, p. 181-192.

Blumenstock, D.I., and Price, Saul, 1967, Climate of Hawaii, in Climates of the States, no. 60-51, Climatography of the United States: U.S. Department of Commerce.

Bruijnzeel, L.A., 2001, Hydrology of tropical montane cloud forests; a reassessment: Land Use and Water Resources Research, v. 1, p. 1.1-1.18.

Bruijnzeel, L.A., and Veneklaas, E.J., 1998, Climatic conditions and tropical montane forest productivity-the fog has not lifted yet: Ecology, v. 79, no. 1, p. 3-9.

Bruijnzeel, L.A.S., Eugster, Werner, and Burkard, Reto, 2005, Fog as a hydrologic input, chap. 38 of Anderson, M.G., ed., Encyclopedia of Hydrological Sciences: Hoboken, New Jersey, John Wiley and Sons, Ltd., p. 559-582.

Calder, Ian, and Dye, Peter, 2001, Hydrological impacts of invasive alien plants: Land Use and Water Resources Research, v. 1, p. 8.1-8.12.

Contor, B.A., 2004, Recharge on non-irrigated lands: Idaho Water Research Institute Technical Report 04-006, 19 p.

County of Hawai ‘i, 2005, County of Hawai 'i general plan: http://www.hawaii-county.com/la/gp/2005/main.html.

County of Hawai 'i, 2006, Hawai 'i County water use and development plan update, draft report, Hawai'i water plan: County of Hawai 'i, Department of Water Supply, http:// www.hawaiidws.org/.

County of Hawai 'i, 2007, Hawai 'i County code, chapter 25, zoning code: County of Hawai'i,.Planning Department, http://www.state.hi.us/dbedt/gis/hawctyzoning.htm.

County of Hawai'i, 2008, Mapping the future, Kona community development plan, volume 2: County of Hawai'i, Planning Department, http://www.hcrc.info/community-planning/community-development-plans/kona/cdp-final-drafts/. 
County of Hawai'i, 2009, Sewer coverage maps: County of Hawai 'i, Department of Environmental Management, http:// www.co.hawaii.hi.us/env_mng/wastewater.htm.

Crockford, R.H., and Richardson, D.P., 2000, Partitioning rainfall into throughfall, stemflow and interception; effect of forest type, ground cover and climate: Hydrological Processes, v. 14, p. 2903-2920.

DeLay, J.K., 2005, Canopy water balance on an elfin cloud forest at Alakahi, Hawai 'i: Honolulu, University of Hawai ' $\mathrm{i}$, M.S. thesis, 78 p.

Dirks, K.N., Hay, J.E., Stow, C.D., and Harris, D., 1998, High-resolution studies of rainfall on Norfolk Island, part II. Interpolation of rainfall data: Journal of Hydrology, v. 208, nos. 3-4, p. 187-193.

Ekern, P.C., 1964, Direct interception of cloud water on Lanaihale, Hawaii: Soil Science Society of America Proceedings, v. 28 , no. 3, p. 419-421.

Ekern, P.C., 1966, Evaporation from bare low humic latosol in Hawaii: Journal of Applied Meteorology, v. 5, no. 4, p. 431-435.

Ekern, P.C., 1971, Use of water by sugarcane in Hawaii measured by hydraulic lysimeters: Proceedings of the International Society of Sugar Cane Technologists, v. 14, p. 805-812.

Ekern, P.C., and Chang, J.H., 1985, Pan evaporation; State of Hawai 'i, 1894-1983: State of Hawai 'i, Department of Land and Natural Resources, Division of Water and Land Development, Report R74, 172 p.

Engott, J.A., and Vana, T.T., 2007, Effects of agricultural landuse changes and rainfall on ground-water recharge in central and west Maui, Hawai 'i, 1926-2004: U.S. Geological Survey Scientific Investigations Report 2007-5103, 56 p.

Fares, Ali, 2008, Water management software to estimate crop irrigation requirements for consumptive use permitting in Hawaii: State of Hawai 'i, Commission on Water Resource Management, http://hawaii.gov/dlnr/cwrm/publishedreports/ PR200808.pdf.

Fontaine, R.A., 2003, Availability and distribution of base flow in lower Honokōhau Stream, island of Maui, Hawaii: U.S. Geological Survey Water-Resources Investigations Report 03-4060, $37 \mathrm{p}$.

Fukunaga, L.K., 1978, Some agroclimatic, economic, ecological, and site considerations that condition the practice of drip irrigation in Hawaii's sugar industry: University of Hawai ${ }^{i}$, M.S. thesis, 181 p.
Gaskill, T.G.R., 2004, Hydrology of forest ecosystems in the Honouliuli preserve; implications for groundwater recharge and watershed restoration: Honolulu, University of Hawai ' $i$, Ph.D. dissertation, 177 p.

Giambelluca, T.W., 1983, Water balance of the Pearl HarborHonolulu basin, Hawai 'i, 1946-1975: University of Hawai 'i Water Resources Research Center Technical Report no. 151, $151 \mathrm{p}$.

Giambelluca, T.W., and Nullet, Dennis, 1991, Influence of the trade-wind inversion on the climate of a leeward mountain slope in Hawaii: Climate Research, v. 1, p. 207-216.

Giambelluca, T.W., and Oki, D.S., 1987, Temporal disaggregation of monthly rainfall data for water balance modeling, in Proceedings of the Vancouver Symposium, August 1987The Influence of Climate Change and Climatic Variability on the Hydrologic Regime and Water Resources: International Association of Hydrologic Sciences Publication No. 168, p. 255-267.

Giambelluca, Tom., and Sanderson, Marie, 1993, The water balance and climatic classification, chap. 4 of Sanderson, Marie, ed., Prevailing trade winds: Honolulu, Hawai 'i, University of Hawai'‘ Press, p. 56-72.

Giambelluca, T.W., and Schroeder, T.A., 1998, Climate, in Juvik, S.P., and Juvik, J.O., eds., Atlas of Hawai' ${ }^{i}$, (3d ed.): Honolulu, University of Hawai 'i Press.

Giambelluca, T.W., Nullet, M.A., and Schroeder, T.A., 1986, Rainfall atlas of Hawai' $i$ : State of Hawai' $i$, Department of Land and Natural Resources, Division of Water and Land Development, Report R76, 267 p.

Giambelluca, T.W., Delay, J.K., Takahashi, M., Mudd, R.G., Huang, M., Asner, G.P., Martin, R.E., and Nullet, M.A., 2009a, Effects of canopy wetness on evapotranspiration in native and invaded tropical montane cloud forest in Hawai ' $\mathrm{i}$ : American Geophysical Union, Fall Meeting 2009, abstract \#H31G-01.

Giambelluca, T.W., Martin, R.E., Asner, G.P., Huang, Maoyi, Mudd, R.G., Nullet, M.A., DeLay, J.K., and Foote, David, $2009 \mathrm{~b}$, Evaporation and energy balance of native wet montane cloud forest in Hawai 'i: Agricultural and Forest Meteorology, v. 149, no. 2, p. 230-243.

Gomez-Peralta, Daniel, Oberbauer, S.F., McClain, M.E., and Philippi, T.E., 2008, Rainfall and cloud-water interception in tropical montane forests in the eastern Andes of central Peru: Forest Ecology and Management, v. 255, p. $1315-1325$.

Hunsaker and Associates Irvine, Inc., 2007, Hydrology and hydraulic analysis for The Shores at Kohanaiki, County of Hawaii: Prepared for Rutter/KW Kohanaiki, LLC., Irvine, Calif., variously paginated. 
Intergovernmental Panel on Climate Change, 2007, Climate change 2007-synthesis report. Contribution of working groups I, II, and III to the fourth assessment report of the Intergovernmental Panel on Climate Change (IPCC), Core writing team, Pachauri, R.K., and Reisinger, Andy, eds: Geneva, Switzerland, IPCC, 104 p.

Izuka, S.K., Oki, D.S., and Chen, C., 2005, Effects of irrigation and rainfall reduction on ground-water recharge in the Lihue Basin, Kauai, Hawaii: U.S. Geological Survey Scientific Investigations Report 2005-5146, 48 p.

Izuka, S.K., Senter, C.A., and Johnson, A.G., 2009, Reconnaissance assessment of the potential for roadside dry wells to affect water quality on the island of Hawai ' $i$ : U.S. Geological Survey Scientific Investigation Report 2009-5249, $55 \mathrm{p}$.

Jenny, Hans, 1994, Factors of soil formation: a system of quantitative pedology: New York, Dover Publications, Inc., $191 \mathrm{p}$.

Jordan, C.F., and Heuveldop, J., 1981, The water budget of an Amazonian rain forest: Acta Amazonica, v. 11, p. 87-92.

Juvik, J.O., and Ekern, P.C., 1978, A climatology of mountain fog on Mauna Loa, Hawaii Island: University of Hawai 'i Water Resources Research Center Technical Report no. 118, $63 \mathrm{p}$.

Juvik, J.O., and Nullet, Dennis, 1994, A climate transect through tropical montane rain forest in Hawaii: Journal of Applied Meteorology, v. 33, no. 11, p. 1304-1312.

Juvik, J.O., and Nullet, Dennis, 1995, Relationships between rainfall, cloud-water interception, and canopy throughfall in a Hawaiian montane forest, chap. 11 of Hamilton, L.S., Juvik, J.O., and Scatena, F.N., eds., Tropical montane cloud forests: New York, Springer-Verlag, p. 165-182.

Juvik, J.O., Nullet, D., Banko, P., and Hughes, K., 1993, Forest climatology near the tree line in Hawai' 1 : Agricultural and Forest Meteorology, v. 66, nos. 3-4, p. 159-172.

Kagawa, Aurora, Sack, Lawren, Duarte, Ka'eo, and James, Shelley, 2009, Hawaiian native forest conserves water relative to timber plantation; species and stand traits influence water use: Ecological Applications, v. 19, no. 6, p. 1429-1443.

Kanehiro, B.Y., and Peterson, F.L., 1977, Groundwater recharge and coastal discharge for the northwest coast of the island of Hawai' $i$; a computerized water budget approach: Honolulu, Hawai 'i, University of Hawai 'i Water Resources Research Center Technical Report no. 110, 83 p.
Langenheim, V.A.M., and Clague, D.A., 1987, The HawaiianEmperor volcanic chain, part II, stratigraphic framework of volcanic rocks of the Hawaiian Islands, chap. 1 of Decker, R.W., Wright, T.L., and Stauffer, P.H., eds., Volcanism in Hawaii: U.S. Geological Survey Professional Paper 1350, v. 1, p. $55-84$

Lockwood, J.P., and Lipman, P.W., 1987, Holocene eruptive history of Mauna Loa Volcano, chap. 18 of Decker, R.W., Wright, T.L., and Stauffer, P.H., eds., Volcanism in Hawaii: U.S. Geological Survey Professional Paper 1350, v. 1, p. 509-535.

Loope, L.L., 1998, Hawaii and the Pacific Islands, in Mac, M.J., Opler, P.A., Haecker, C.E.P., and Doran, P.D., eds., Status and trends of the nation's biological resources-vol. 2: Reston, Virginia, U.S. Geological Survey, p. 747-774.

Macdonald, G.A., and Abbott, A.T., 1970, Volcanoes in the sea: Honolulu, Hawai 'i, University of Hawai'i Press, 441 p.

Mair, Alan, 2009, Effects of rainfall variability and groundwater pumping on streamflow in the upper Mākaha Valley: Honolulu, University of Hawai'i, Ph.D. dissertation, 200 p.

McJannet, David, Wallace, Jim, Fitch, Peter, Disher, Mark, and Reddell, Paul, 2007, Water balance of tropical rainforest canopies in north Queensland, Australia: Hydrological Processes, v. 21, p. 3473-3484.

Mendonca, B.G., and Iwaoka, W.T., 1969, The trade wind inversion on the slopes of Mauna Loa, Hawaii: Journal of Applied Meteorology, v. 8, no. 2, p.213-219.

Minyard, W.P., Giambelluca, T.W., and Nullet, Dennis, 1994, Elevational patterns of climate on the leeward slope of east Maui, Hawaii: University of Hawai 'i at Mānoa, Cooperative National Park Resources Studies Unit, Technical Report 92, $50 \mathrm{p}$.

Montieth, J.L., 1965, Evaporation and the environment: Society for Experimental Biology, 19th Symposium, p. 205-235.

Nullet, Dennis, and Sanderson, Marie, 1993, Radiation and energy balances and air temperature, chap. 3 of Sanderson, Marie, ed., Prevailing trade winds: Honolulu, Hawai 'i, University of Hawai'i Press, p. 37-55.

Oki, D.S., 1999, Geohydrology and numerical simulation of the ground-water flow system of Kona, island of Hawaii: U.S. Geological Survey Water Resources Investigations Report 99-4073, 70 p.

Oki, D.S., 2002, Reassessment of ground-water recharge and simulated ground-water availability for the Hāwī area of North Kohala, Hawaii: U.S. Geological Survey Water Resources Investigations Report 02-4006, 62 p. 
Oki, D.S., 2008, The significance of accounting order for evapotranspiration and recharge in monthly and daily threshold-type water budgets: U.S. Geological Survey Scientific Investigations Report 2008-5163, 11 p.

Penman, H.L., 1948, Natural evaporation from open water, bare soil, and grass: Proceedings of the Royal Society of London, A193, p. 120-146.

Pratzert, W.C., 1969, Eddies in Hawaiian waters: University of Hawai 'i, Hawai 'i Institute of Geophysics Report HIG-69-8, $51 \mathrm{p}$.

Sanderson, Marie, 1993, Introduction, chap. 1 of Sanderson, Marie, ed., Prevailing trade winds: Honolulu, Hawai 'i, University of Hawai 'i Press, p. 1-11.

Santiago, L.S., Goldstein, Guillermo, Meinzer, F.C., Fownes, J.H., and Muller-Dombois, Dieter, 2000, Transpiration and forest structure in relation to soil waterlogging in a Hawaiian montane cloud forest: Tree Physiology, v. 20, no. 10, p. 673-681.

Savenije, H.H.G., 2004, The importance of interception and why we should delete the term evapotranspiration from our vocabulary: Hydrological Processes, v. 18, p. 1507-1511.

Schellekens, J., Bruijnzeel, L.A., Wickel, A.J., Scatena, F.N., and Silver, W.L., 1998, Interception of horizontal precipitation by elfin cloud forest in the Luquillo Mountains, eastern Puerto Rico, in Schemenauer, R.S., and Bridgman, H.A., eds., First International Conference on Fog and Fog Collection: Vancouver, p. 29-32.

Scholl, M.A., Giambelluca, T.W., Gingerich, S.B., Nullet, M.A., and Loope, L.L., 2007, Cloud water in windward and leeward mountain forests; the stable isotope signature of orographic cloud water: Water Resources Research, v. 43, W12411, 13 p.

Schroeder, Thomas, 1993, Climate controls, chap. 2 of Sanderson, Marie, ed., Prevailing trade winds: Honolulu, Hawai 'i, University of Hawai 'i Press, p. 12-36.

Shade, P.J., 1995, Water budget for the Kohala area, island of Hawaii: U.S. Geological Survey Water Resources Investigations Report 95-4114, 19 p.

Shade, P.J., and Nichols, W.D., 1996, Water budget and the effects of land-use changes on ground-water recharge, Oahu, Hawaii: U.S. Geological Survey Professional Paper $1412-\mathrm{C}, 38 \mathrm{p}$.

Shuttleworth, W.J., 1993, Evaporation, chap. 4 of Maidment, D.R., ed., Handbook of hydrology: New York, McGrawHill, p. 4.1-4.53.

State of Hawai 'i, 1980, Agricultural land use maps: State of Hawai 'i, Department of Agriculture, http://www.state.hi.us/ dbedt/gis/alum.htm.
State of Hawai 'i, 1989, Hawaii County water use and development plan, Hawaii water plan: State of Hawai 'i, Commission on Water Resource Management, variously paginated.

State of Hawai 'i, 1990, Water resources protection plan, volumes I and II, June 1990: State of Hawai 'i, Commission on Water Resource Management, variously paginated.

State of Hawai ' $i$, 2001, 2000 census blocks: State of Hawai 'i, Office of Planning, http://www.state.hi.us/dbedt/gis/ blocks00.htm.

State of Hawai ${ }^{i}$ i, 2008, Water resource protection plan, June 2008: State of Hawai 'i, Commission on Water Resource Management, variously paginated.

Stearns, H.T., and Macdonald, G.A., 1946, Geology and ground-water resources of the island of Hawaii: Territory of Hawaii, Hawaii Division of Hydrography Bulletin 9, 363 p.

Takasaki, K.J., and Mink, J.F., 1985, Evaluation of major dikeimpounded ground-water reservoirs, island of Oahu: U.S. Geological Survey Water-Supply Paper 2217, 77 p.

Thornthwaite, C.W., and Mather, J.R., 1955, The water balance: Publications in Climatology, v. 8, no. 1, p. 1-104.

Timm, Oliver, and Diaz, H.F., 2009, Synoptic-statistical approach to regional downscaling of IPCC twenty-first-century climate projections; seasonal rainfall over the Hawaiian Islands: Journal of Climate, v. 22, no. 16, p. 4261-4280.

Timm, Oliver, Hamilton, Kevin, Diaz, H.F., Giambelluca, Thomas, and Mehrhoff, L.A., 2009, Statistical downscaling of IPCC climate scenarios onto the Hawaiian Islands: University of Hawai 'i at Mānoa, Asia-Pacific Data Research Center, http://apdrc.soest.hawaii.edu/projects/SD/.

Tobon Marin, C., Bouten, W., and Sevink, J., 2000, Gross rainfall and its partitioning into throughfall, stemflow and evaporation of intercepted water in four forest ecosystems in western Amazonia: Journal of Hydrology, v. 237, nos. 1-2, p. $40-57$.

U.S. Census Bureau, 2009, Table 1; annual estimates of the resident population for counties of Hawaii, April 1, 2000 to July 1, 2008: U.S. Census Bureau, Population Division.

U.S. Department of Agriculture, 2008, Soil survey geographic (SSURGO) database for the island of Hawaii: U.S. Department of Agriculture, Natural Resources Conservation Service, http://soildatamart.nrcs.usda.gov/ [accessed November 2008].

U.S. Geological Survey, 2006, A GAP analysis of Hawaii: U.S. Geological Survey, The Hawaii GAP Analysis Project, http://gapanalysis.nbii.gov/portal/community/GAP_Analysis_Program/Communities/GAP_Home/. 
Viessman, Warren, Jr., and Lewis, G.L., 2003, Introduction to hydrology (5th ed.): Upper Saddle River, N.J., Prentice Hall, $612 \mathrm{p}$.

Villegas, J.C., Tobon, Conrado, and Breshears, D.D., 2007, Fog interception by non-vascular epiphytes in tropical montane cloud forests; dependencies on gauge type and meteorological conditions: Hydrological Processes, v. 22, no. 14, p. 2484-2492.

Wahl, K.L., and Wahl, T.L., 1995, Determining the flow of Comal Springs at New Braunfels, Texas: Proceedings of Texas Water '95, a component conference of the American Society of Civil Engineers International Conference on Water Resources Engineering, 1st, San Antonio, Texas, 1995, p. 77-86.

Waimea Water Services, 2004, Water resources of the South $\mathrm{Kona} / \mathrm{Ka}$ ' $\mathrm{u}$ water master plan area: prepared for the County of Hawai' $i$ Office of the Mayor and Townscape, Inc.
Walmsley, J.L., Schemenauer, R.S., and Bridgman, H.A., 1996, A method for estimating the hydrologic input from fog in mountainous terrain: Journal of Applied Meteorology, v. 35 , no. 12 , p. 2237-2249.

Wentworth, C.K., and Macdonald, G.A., 1953, Structures and forms of basaltic rocks in Hawaii: U.S. Geological Survey Bulletin 994, 98 p.

Western Regional Climate Center, 2009, Historical climate information: Western Regional Climate Center, http://www. wrcc.dri.edu/ [accessed April 2009].

Yang, Yang, and Chen, Yi-Leng, 2003, Circulations and rainfall on the lee side of the island of Hawaii during HaRP: Monthly Weather Review, v. 131, no. 10, p. 2525-2542. 


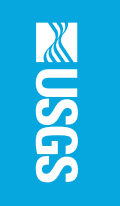

뭉

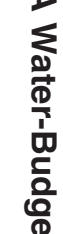

응

ํㅡㄹ

क

品

号

을

오

ำ

气ำ

Ф)

ग्ञ

옹

옥

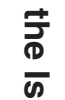

흠

옥

꼻

क

믈

言

历

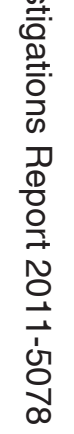

